Universidad de Lima

Facultad de Comunicación

Carrera de Comunicación

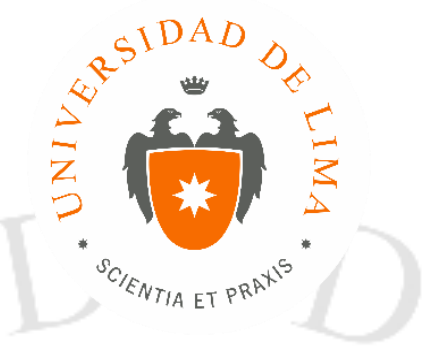

\title{
EL VALOR AGREGADO DE LA MÚSICA EN SPOTS PUBLICITARIOS DE PERFUMES PARA MUJERES ADOLESCENTES EN LIMA METROPOLITANA
}

Trabajo de investigación para optar el Título Profesional de Licenciado en

Comunicación

\section{Diana Alejandra Torres Altez}

Código 20091131

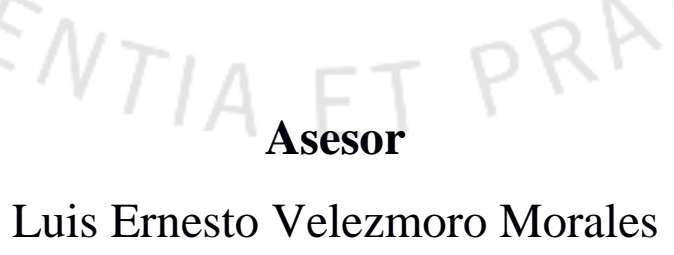

Lima - Perú

[Agosto del 2018] 


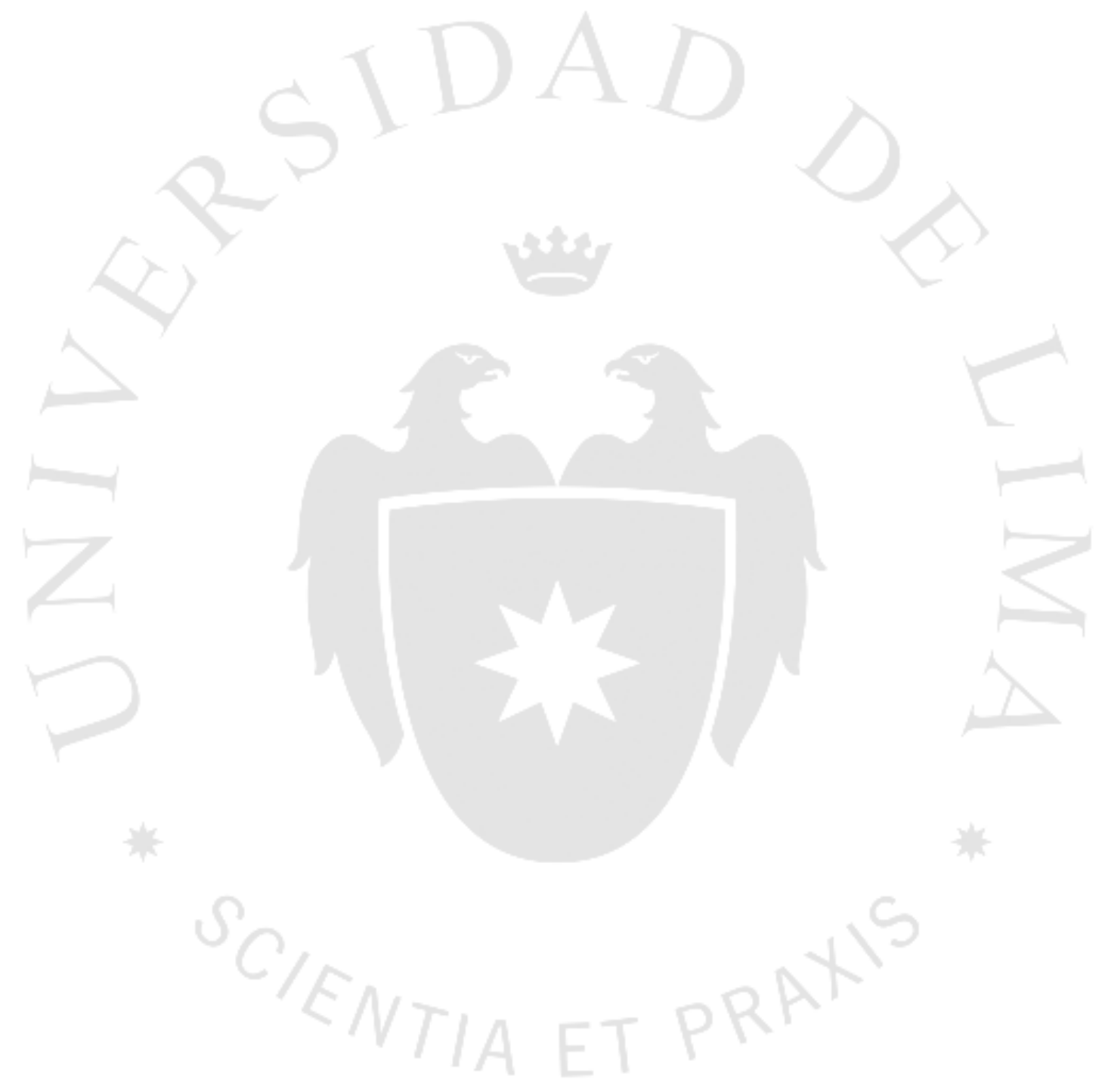




\section{EL VALOR AGREGADO DE LA MÚSICA EN SPOTS PUBLICITARIOS DE PERFUMES PARA MUJERES ADOLESCENTES EN LIMA METROPOLITANA}




\section{TABLA DE CONTENIDO}

INTRODUCCIÓN 1

CAPÍTULO I: MARCO TEÓRICO ........................................................................... 2

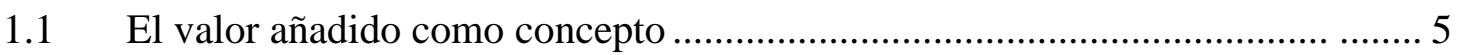

1.2 La televisión como soporte 2D y el spot publicitario televisivo ...................... 6

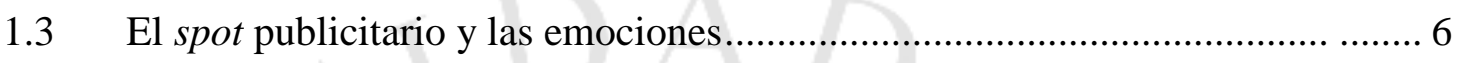

1.4 El spot publicitario y la música ............................................................. 7

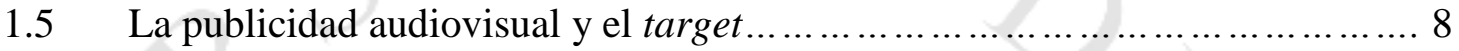

1.6 El perfume como concepto-producto y su relación con el target ...................... 11

1.7 La música y sus principales elementos constitutivos ..................................... 13

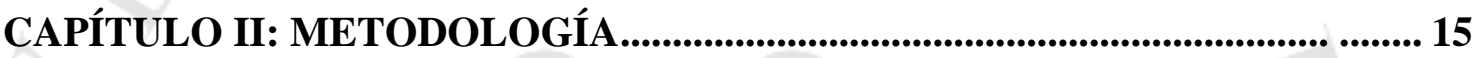

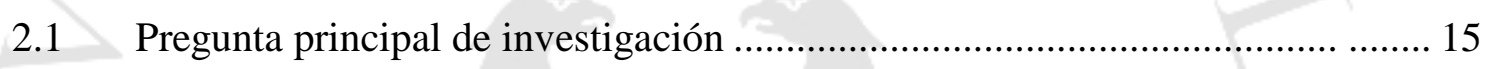

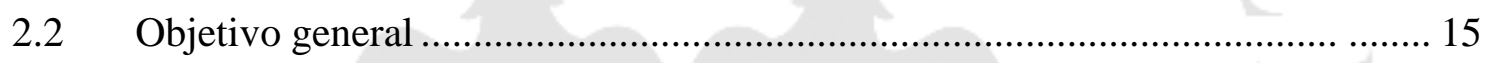

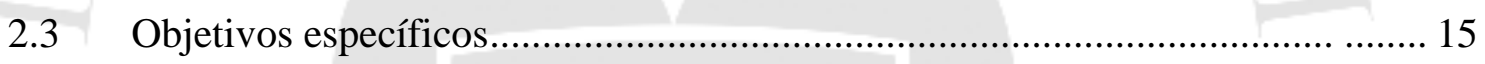

2.4 Descripción de la investigación.................................................................. 15

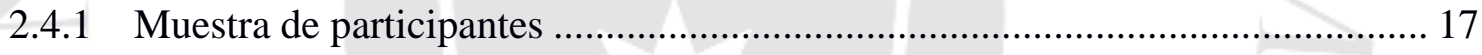

2.4.2 Muestra de expertos................................................. 18

2.4.3 Técnica e instrumento de recolección de datos ................................................. 18

CAPÍTULO III: RESULTADOS .................................................................................. 20

3.1 Presentación de marcas ..................................................................................... 20

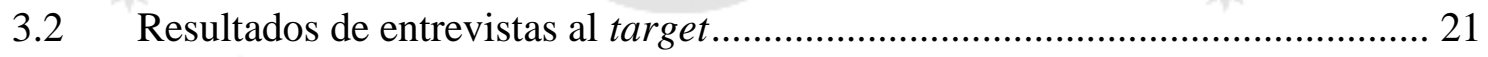

3.2.1 Análisis cuantitativo del spot Natura A (modificado)..................................... 22

3.2.2 Análisis cuantitativo del spot Natura B (original).......................................... 26

3.2.3 Análisis cuantitativo del spot Cacharel A (modificado) .................................. 29

3.2.4 Análisis cuantitativo del spot Cacharel B (original) ...................................... 33

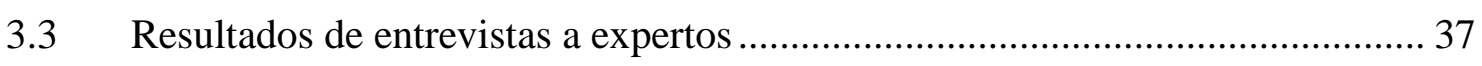

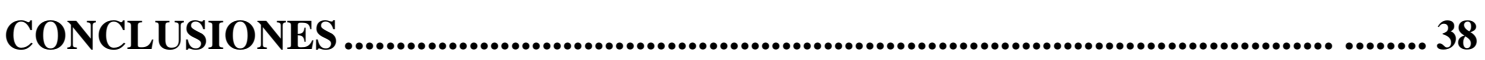

RECOMENDACIONES................................................................................... 46

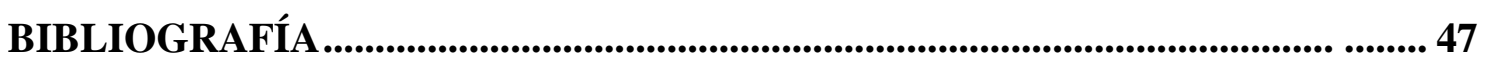

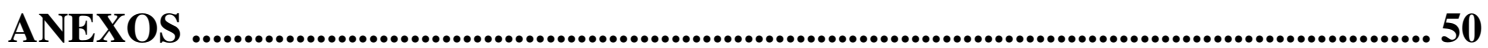




\section{ÍNDICE DE TABLAS}

Tabla 1.5.2 Elementos que más atraen en un comercial de televisión............................... 10

Tabla 1.6.1 Poder de decisión de adolescentes y jóvenes.................................................. 12

Tabla 1.6.2 Penetración de uso de productos de uso personal................................. 12

Tabla 4.1.1 Análisis musical del spot "Humor!” de Natura ............................................... 38

Tabla 4.1.2 Análisis musical del spot “Amor amor" de Cacharel ..................................... 38

Tabla 4.2.1 Codificación de respuestas a las entrevistas, spot "Humor!" de Natura.......... 39

Tabla 4.2.2 Codificación de respuestas a las entrevistas, spot "Amor amor" de Cacharel 40 


\section{ÍNDICE DE FIGURAS}

Figura 0.1 Composición de la población de adolescentes y jóvenes...................... 3

Figura 0.2 Género y edad de la población de adolescentes y jóvenes ............................ 3

Figura 0.3 Uso habitual de medios de comunicación......................................... 4

Figura 0.4 Frecuencia de sintonía de televisión de señal abierta................................... 4

Figura 1.3. 1 Poder de los sentidos en el ser humano ................................................ 7

Figura 1.5.1 Percepción del contenido musical en un comercial ..................................... 10

Gráfico 3.2.1.1 Emociones que transmite el spot ........................................ 22

Gráfico 3.2.1.2 Nivel socioeconómico que le asignaría al spot...................................... 23

Gráfico 3.2.1.3 Precio que le asigna al producto en soles .............................................. 23

Gráfico 3.2.1.4 Edad con que se relaciona el spot.......................................................... 24

Gráfico 3.2.1.5 Estilo de vida reflejado en el spot......................................................... 24

Gráfico 3.2.2.1 Emociones que le transmite el spot ....................................................... 26

Gráfico 3.2.2.2 Nivel socioeconómico que le asigna al spot ............................................ 26

Gráfico 3.2.2.3 Precio que le asigna en soles al producto ........................................... 27

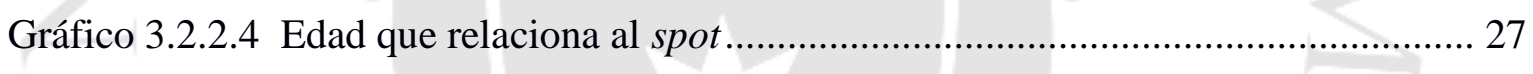

Gráfico 3.2.2.5 Estilo de vida reflejado en el spot ...................................................... 28

Gráfico 3.2.3.1 Emociones que le transmite el spot ....................................................... 29

Gráfico 3.2.3.2 Nivel socioeconómico que le asignaría al spot ......................................... 30

Gráfico 3.2.3.3 Precio que le asigna en soles al producto ............................................. 30

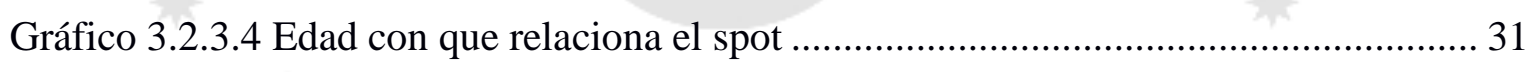

Gráfico 3.2.3.5 Estilo de vida reflejado en el spot....................................................... 31

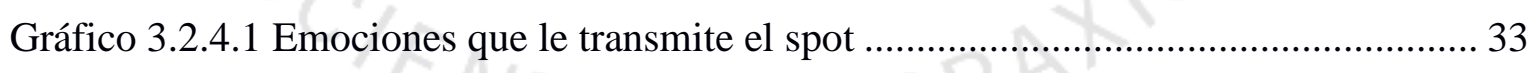

Gráfico 3.2.4.2 Nivel socioeconómico que le asigna al spot ............................................ 33

Gráfico 3.2.4.3 Precio que le asigna en soles al producto ............................................... 34

Gráfico 3.2.4.4 Edad con que relaciona el spot .............................................................. 35

Gráfico 3.2.4.5 Estilo de vida reflejado en el spot ....................................................... 36 


\section{ÍNDICE DE ANEXOS}

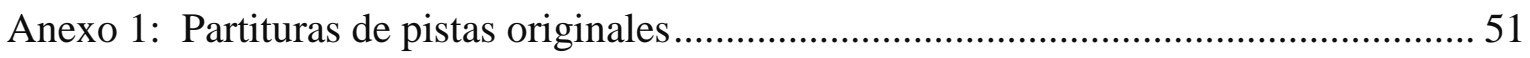

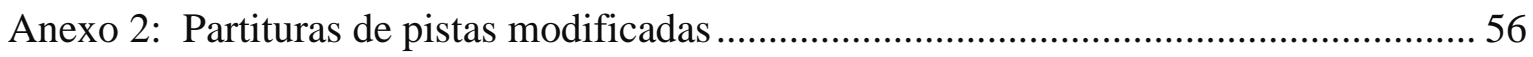

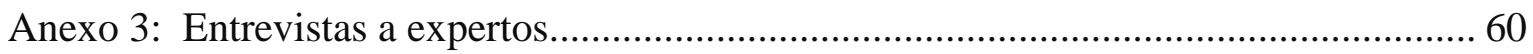




\section{INTRODUCCIÓN}

Esta investigación aborda el estudio del valor agregado de la música en spots publicitarios de perfumes dirigidos a público femenino adolescente de los niveles socioeconómicos A y B en Lima Metropolitana. El objetivo de la investigación es conocer los efectos de la música en la construcción de significados que permiten la apropiación del contenido de spots por su público objetivo. Se analiza la relación entre imagen y música; el significado (sentido) que la música otorga al anuncio y si se genera algún tipo de apropiación de la música como parte del proceso de aceptación (reconocimiento) de la publicidad. El estudio es relevante dado que investiga el valor que el consumidor le concede de manera inconsciente a un pilar fundamental en la publicidad audiovisual y que muchas veces pasa desapercibido. Cabe destacar que no hemos encontrado estudios previos sobre el tema respecto a música, perfumes y mujeres adolescentes en Lima Metropolitana. A nivel metodológico se ha seguido un modelo experimental a través de la modificación de pistas de música en dos casos de publicidad audiovisual que han sido mostrados a una muestra del target, a la que posteriormente se ha aplicado una entrevista a profundidad (investigación cualitativa); y se analizan estadísticamente sus respuestas (análisis cuantitativo). De manera complementaria, se realizaron entrevistas (cualitativas) a productores musicales del ámbito publicitario considerados como expertos. Los resultados muestran un sobresaliente cambio de percepción de las participantes ante diferentes pistas musicales en un mismo spot.

Palabras clave: Música, publicidad audiovisual, emociones, mujeres, perfumes, percepción, Lima 


\section{CAPÍTULO I: MARCO TEÓRICO}

En la actualidad es relevante para las marcas tener un acercamiento a su público objetivo o target que sea amigable y que pueda generar lealtad hacia ellas, mediante la creación de lazos de identificación. Para ello utilizan diversas estrategias comunicativas en medios como spots televisivos, redes sociales, radio, presencia en internet, publicidad gráfica en medios impresos y exteriores, entre otros. La forma en que estas estrategias son desarrolladas y las herramientas que se utilizan para ello representan un campo decisivo para alcanzar sus objetivos comerciales.

Según reporta la revista Marketing News, el mercadólogo Martin Lindstrom manifestó en el lanzamiento de Expomarketing 2007 que:

Hay que lograr compromiso emocional con el consumidor para que recuerde la marca, y para permanecer en su memoria se debe tocar la fibra de sus sentimientos; por eso hay que crear una historia con la cual pueda identificarse y comprometerse. [...] Dele a la comunicación un tono emocional para que la marca, además de ser recordada, ocupe un lugar en la vida del consumidor. (Brand Sense: publicidad a través del imperio de los sentidos, 2007, p. 5)

Dentro de este panorama, el uso de la música como un elemento complementario, con fines de persuasión y de creación de un vínculo emocional más fuerte, especialmente en medios audiovisuales, contribuye a la finalidad de diferenciar una determinada marca y posicionarla positivamente en el imaginario del target.

La investigación que reportamos en el presente artículo analiza cómo el valor añadido de la música en la sincresis audiovisual - la unión entre el fenómeno sonoro y visual (Chion, 1990, cap. IV)—, tiene efecto en el significado construido y en la apropiación que hace de los spots publicitarios de perfumes el público femenino adolescente (de 14 a 20 años de edad) de niveles socioeconómicos A y B (alto y medioalto poder adquisitivo), entendiendo el nivel socioeconómico como:

Una medida total que combina la parte económica y sociológica de la preparación laboral de una persona y de la posición económica y social individual o familiar en relación a otras personas. [...] Incluye tres aspectos básicos: los ingresos económicos, nivel educativo y ocupación de los padres. (Vera-Romero y Vera-Romero, 2013, p. 41) 
El ámbito geográfico de nuestra intervención ha sido Lima Metropolitana, donde el target aproximadamente "representa el $15,7 \%$ de población total del lugar, mientras que el $51 \%$ refiere solo a la población femenina. El $4.8 \%$ pertenecen al nivel socioeconómico A y el 15.6\% al B”..(Ipsos Apoyo, 2012)

Figura 0.1

Composición de la población de adolescentes y jóvenes en Lima metropolitana (\%)

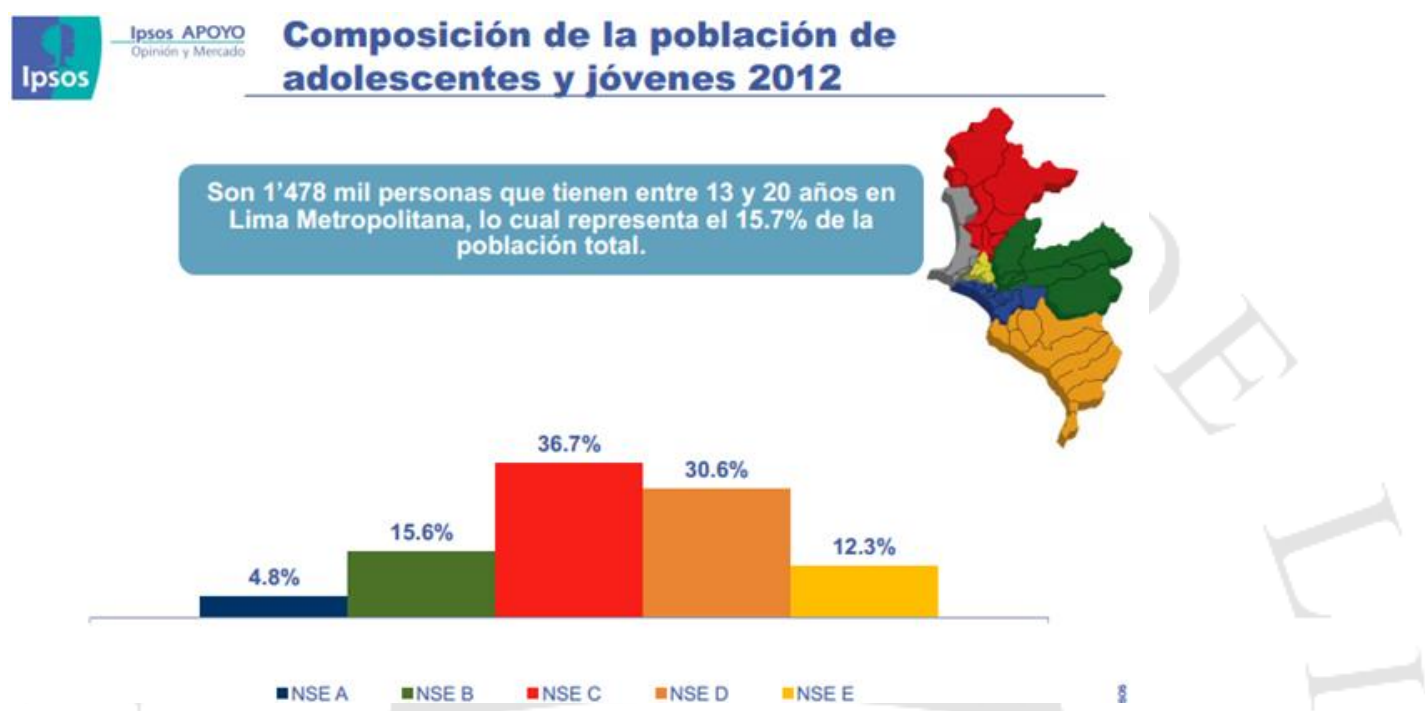

Fuente: Ipsos apoyo, (2012). Perfil del adolescente y el joven. Lima metropolitana.

Figura 0.2

Género y edad de la población de adolescentes y jóvenes en Lima metropolitana (\%)

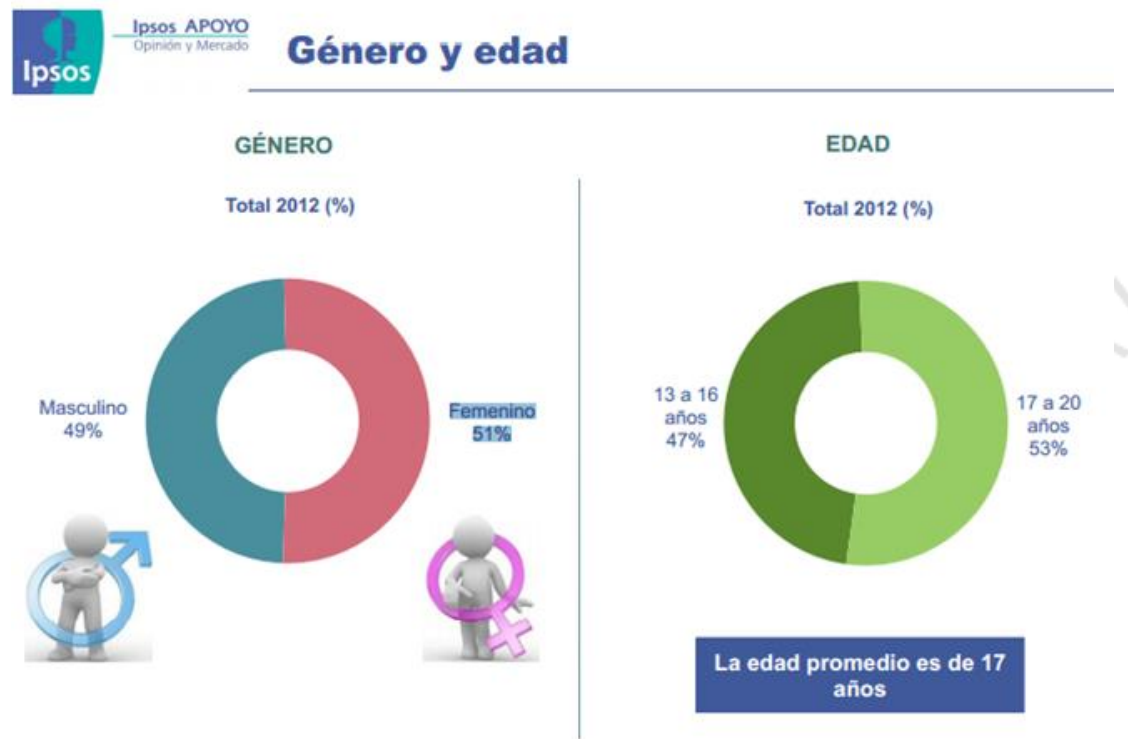

Fuente: Ipsos apoyo, (2012). Perfil del adolescente y el joven. Lima metropolitana. 
Igualmente, mediante encuestas de Ipsos apoyo se deduce que el medio de comunicación con más uso es la TV con señal abierta, seguido por internet y radio. Así mismo la frecuencia de sintonía de televisión de señal abierta es en su mayoría todos los días (Ipsos Apoyo, 2012)

Figura 0.3

Uso habitual de medios de comunicación (\%)

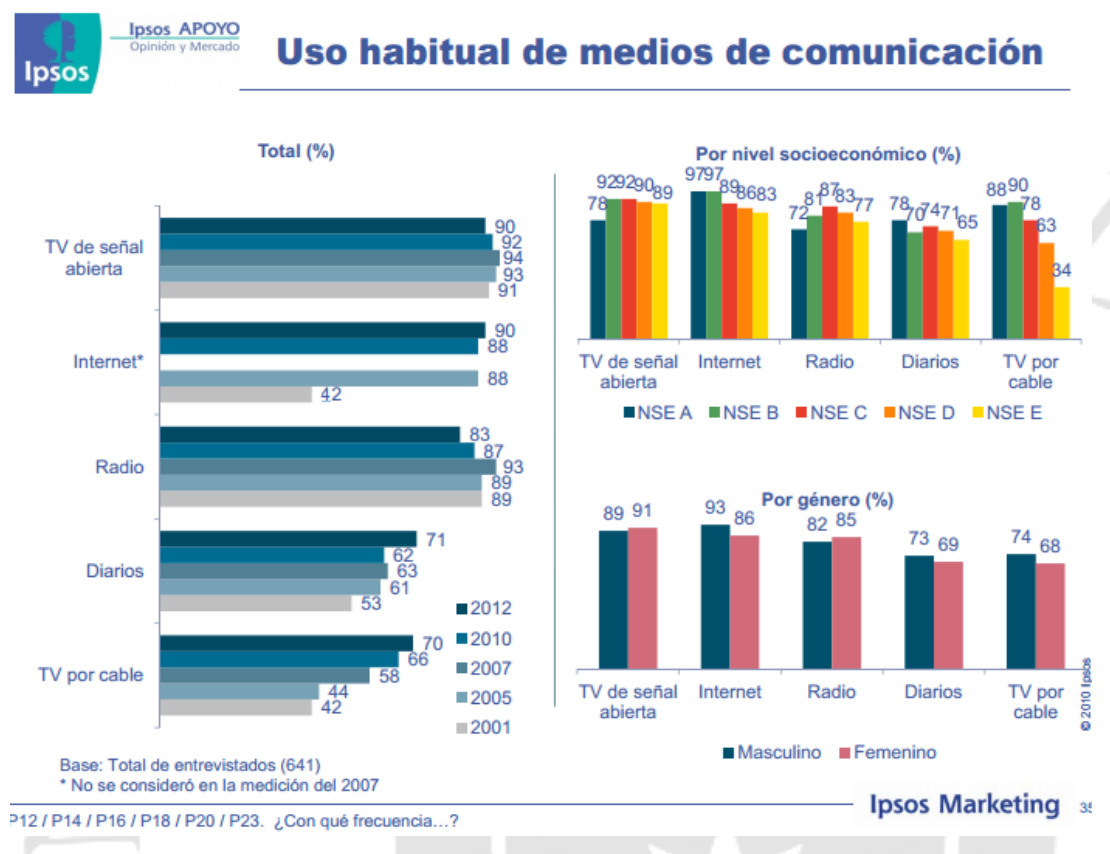

Fuente: Ipsos apoyo, (2012). Perfil del adolescente y el joven. Lima metropolitana.

Figura 0.4

Frecuencia de sintonía de televisión de señal abierta (\%)

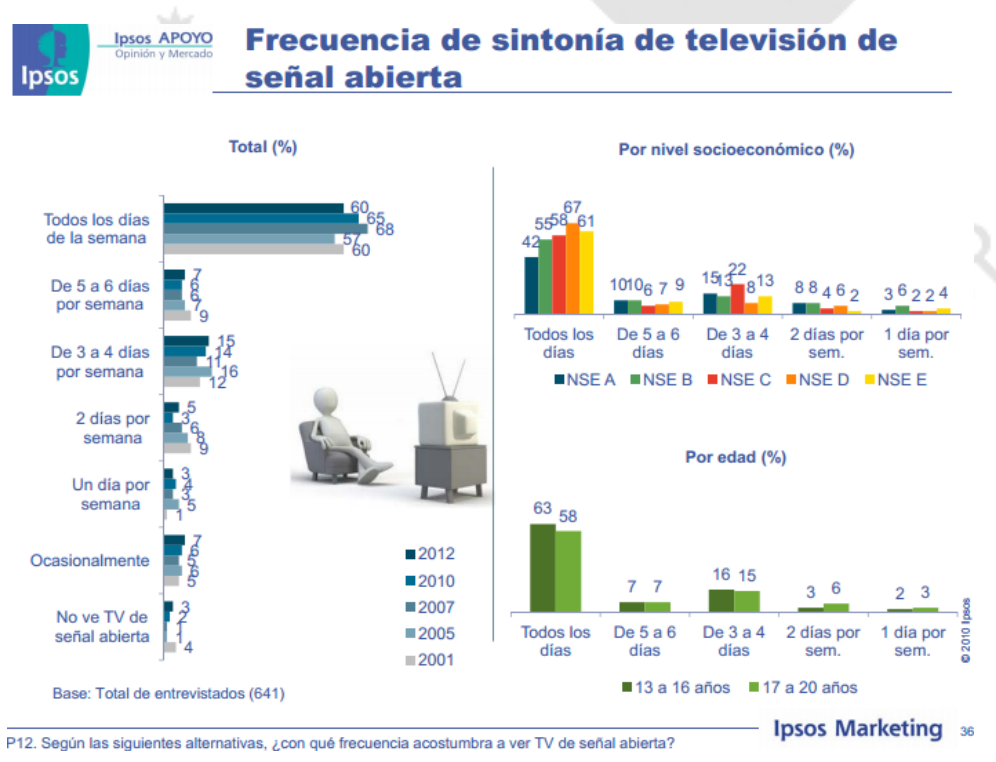

Fuente: Ipsos apoyo, (2012). Perfil del adolescente y el joven. Lima metropolitana. 
Se ha utilizado un método experimental consistente en la modificación de la variable música en dos casos representativos de publicidad audiovisual, y en entrevistas a profundidad a una muestra del público mencionado después de haber observado los spots originales y modificados. Los resultados de estas entrevistas han sido luego cuantificados para facilitar su análisis, construyendo una metodología de base cualitativa con análisis estadístico (cuantitativo).

Para el estudio seleccionamos spots publicitarios de dos marcas representativas de perfumes: la brasileña Natura, y la francesa Cacharel; ambas con publicidad audiovisual destinada a público femenino adolescente por televisión abierta que utiliza formas musicales específicas. En el análisis, tanto de la publicidad (los spots) utilizada para el estudio como de las respuestas ante ella que nos han dado las participantes entrevistadas, así como las ideas expresadas por expertos en el tema, nos permiten interpretar los resultados para evaluar el papel de la música en la reacción de las consumidoras ante la misma en los mensajes publicitarios. Para ello enmarcamos teóricamente temas clave: el concepto de valor añadido; la relación del spot publicitario con las emociones; el papel de la música en el spot publicitario; la televisión como soporte 2D y el spot publicitario; la publicidad audiovisual y el target; el perfume como concepto/producto y su relación con un target específico, y la descripción de elementos básicos de la música que nos permitan tener un acercamiento técnico a ella.

\subsection{El valor añadido como concepto}

"Valor añadido", según se define en el Diccionario de la lengua española (RAE, 2018), es el "incremento de valor de un bien como consecuencia de un proceso productivo o de distribución". Es decir que existe una innovación, un elemento extra, en la elaboración del objeto; de esta manera, el producto tendría la capacidad incluso de crear nuevas necesidades en el target, más allá de su función principal. Asimismo, mediante el valor añadido, el producto puede cubrir necesidades (sean preexistentes o creadas) que lo diferenciarán de otros similares.

De esta manera, en el plano audiovisual se habla acerca de un enriquecimiento del sonido sobre la imagen. Chion (1990), define el valor añadido específicamente del sonido como: 
Por valor añadido designamos el valor expresivo e informativo con el que un sonido enriquece una imagen dada, hasta hacer creer, en la impresión inmediata que de ella se tiene o el recuerdo que de ella se conserva, que esta información o esta expresión se desprende de modo natural de lo que se ve, y está ya contenida en la sola imagen (p.16)

\subsection{La televisión como soporte 2D y el spot publicitario}

La televisión es un medio de comunicación conocido por su capacidad de mezclar imágenes en movimiento (video) y audio en 2D (bidimensional) desde inicios del siglo XX. Según el diario La República (2015) “El Consejo Consultivo de Radio y Televisión (Concortv), organismo multisectorial, informó que a nivel nacional la televisión es el medio de comunicación de mayor consumo (98,3\%). Le siguen la radio (81,3\%), los diarios $(75,2 \%)$ y la internet $(51,2 \%)^{*}$ (párrr.1)

Cabe destacar que al poseer tales herramientas de comunicación se produce una fuerte conexión con el espectador, generando una apelación multisensorial que permite potenciar los mensajes del anunciante. Para Hernán Pérez (2007):

La televisión es el medio de comunicación más importante inventado por el ser humano. No existe otra invención con alcances tan portentosos, y no hay duda de que es capaz de ejercer una influencia importante en el comportamiento de los seres humanos. (p. 15)

Dentro de este panorama, el spot publicitario televisivo está constituido a su vez de imágenes, videos, voces, música, efectos de sonido y/o gráficos en movimiento. Sus contenidos suelen ser narrativos en forma de pequeñas historias o dando a conocer los atributos del producto o servicio que se ofrece con el fin de anunciar sus beneficios y/o factores diferenciales. De igual manera, aparece entre programas, suele durar hasta 60 segundos y llega a una audiencia masiva que representa “cerca de dos tercios de toda la publicidad televisiva“ (Gonzáles y Carrero, 2008, p. 191).

\subsection{El spot publicitario televisivo y las emociones}

El spot publicitario televisivo tiene la capacidad de generar emociones y sensaciones en el público que se manifiestan a través de "redes estimulantes basadas en el placer y en el bienestar para acompañar a los individuos en momentos especiales que les permitan sentir que la vida tiene sentido por esos momentos de intimidad con los suyos" (Vázquez, 2007, p. 38). Siendo su objetivo producir un sentido de pertenencia e identificación en el target, recurre también a indicadores somáticos, es decir, estados 
corporales que se manifiestan en estados emocionales e influyen en las decisiones. De acuerdo con Damasio (1994):

Es probable que la mayoría de los marcadores somáticos que utilizamos en la toma racional de decisiones se haya creado en nuestro cerebro durante el proceso de educación y socialización, mediante la asociación de tipos específicos de estímulos con tipos específicos de estado somático. (Damasio, 1994, p. 203)

Esta asociación beneficia o afecta una experiencia, dependiendo de lo acontecido en el pasado del consumidor y generando de esta manera una especie de "humanización” del producto a través del video, la música y la narrativa construida.

Así mismo cabe recalcar que las emociones están influenciadas por cómo se procesan a través de los sentidos. A continuación su impacto en el ser humano:

Figura 1.3.1

Poder de los sentidos en el ser humano (\%)

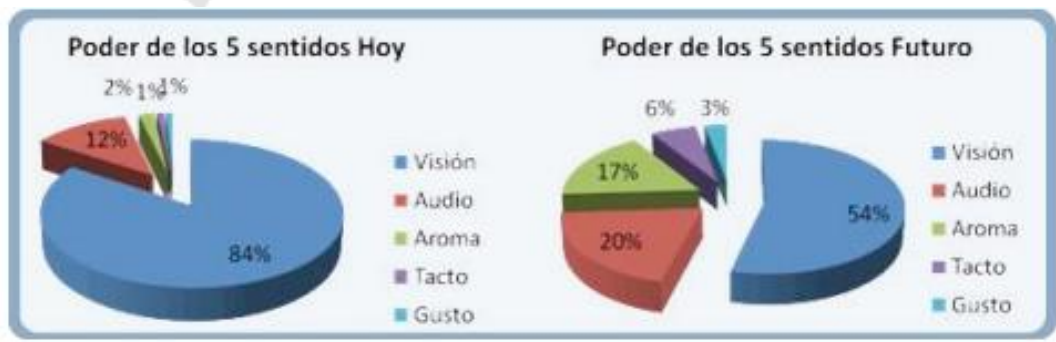

Fuente: Lindstrom, (2005). El poder de los sentidos hoy y en el futuro.

\subsection{El spot publicitario y la música}

En lo que respecta a publicidad, muchas veces no se trata de dar explicaciones racionales por medio del spot, ni de apelar a una interpretación técnica por parte del público, pues este busca en la televisión un espacio de distracción y entretenimiento; es decir que trata de encontrar un espacio en que esté ausente la racionalidad, y es ahí donde la música puede tener un papel fundamental por su poder evocador.

Philip Ball (2010), historiador de la ciencia, ha investigado la presencia de la música en nuestra vida hasta encontrar que todos tenemos un "instinto musical": "la capacidad de escuchar y apreciar patrones sonoros, algo que casi todos poseemos, es la esencia de la musicalidad" (p. 9).

La música se mueve en un terreno donde mandan las sensaciones y tiene la facultad de desatar determinados comportamientos en quien la escucha. No obstante, lo que interesa en la publicidad es la recordación del producto y es ahí donde la música arrastra al oyente y lo sumerge en el mensaje. Esta se dirige a la emotividad y posee una 
enorme capacidad de sugerencia que va más allá de distraer, relajar y desviar la atención de aspectos técnicos hacia valoraciones más emotivas.

Según Balsebre (1994), "se trata de una fuente creadora de imágenes auditivas simbólicas, de ahí su poder como creadora de entornos y concretamente como acento de la imagen emotiva publicitaria” (p. 89). De ahí que pueda generar atribuciones a diversos mensajes. De igual manera, González Martín (1996), experto en comunicación audiovisual, añade: “Considero que la música connota y enmarca significados básicos, llenándolos de sugerencias y sentimientos” (p. 389), teniendo así un importante papel en su relación con la publicidad pues le brinda una suerte de marco no solo comprensible y disfrutable, sino capaz de producir sentido para emitir el mensaje.

En la publicidad audiovisual encontramos fundamentalmente dos clases de música: por una parte están los jingles, breves "canciones” que se caracterizan por aludir con mayor énfasis al producto mediante la repetición del mensaje y de su nombre; los jingles, debido a su "composición ad hoc" (se hacen específicamente para el producto a publicitar) confieren al mensaje una "mayor capacidad de identificación y recuerdo" (Piñeiro-Otero, 2015, p. 672). En el Perú, algunos de ellos se han vuelto hits, como los de Claro ("El tema del verano"), el Banco de Crédito del Perú ("La canción del Cuy Mágico”), o Rímac Seguros (“Todo va a estar bien”).

Por la otra parte está la música de fondo, ya sea creada específicamente para un fin o tomada de archivos. Esta tiene como objetivo crear una atmósfera y generar emociones a través del spot, sin embargo es posible que el mensaje principal quede en segundo plano.

\subsection{La publicidad audiovisual y el target}

La publicidad busca el reconocimiento de un producto o marca, cubriendo necesidades básicas, a nivel interno del consumidor. Este reconocimiento incluye sentimientos de afiliación, deseos, aspiraciones y necesidades humanas propiamente dichas. Dentro de este marco se sabe que las mujeres son un segmento especial para los anunciantes, sobre todo por su tipo de sensibilidad y como este opera en ellas.

Se sabe que la prolactina es una hormona presente en mayor cantidad en mujeres (no gestantes y gestantes) que en hombres. "Durante las emociones, el cerebro de la mujer presenta hasta 8 veces más de actividad, causante de esto, es la prolactina, que, la mujer tiene en abundancia, alrededor de un $60 \%$ más que el hombre. Lo anterior 
explica, porque éste tipo de argumento es más efectivo cuando se los ocupa para persuadir a la mujer. Como afirma Pace (2009), las mujeres lloran cuando están tristes, cuando están contentas y muchas veces frente a un comercial“ (cit. en Marketing directo, Marketing dirigido a la mujer: Un inmenso mercado que presenta grandes desafíos, 29 de noviembre del 2011)

De igual manera, cabe mencionar los ítems con los que se la relaciona a la mujer en la publicidad audiovisual, según en psicólogo Juan Pablo Westphal, en la publicidad a la mujer como consumidora, "se la relaciona con productos que rescaten la sensibilidad, la belleza, la expresión afectiva, la originalidad, etc." (cit. en Mujeres y compras: ¡Me lo llevo!, 14 de octubre de 2012). Este patrón se manifiesta recurrentemente siendo ya un común denominador en los medios masivos.

La socióloga Silvia Lamadrid supone que esto se debe a la "estrecha relación entre imagen e identidad que poseen las mujeres“ (cit. en Mujeres y compras: ¡Me lo llevo!, 14 de octubre de 2012). En el caso de mujeres adolescentes (entre 14 y 20 años de edad) esto podría ser aún más enfático, pues en la etapa de la adolescencia se terminan de manifestar los cambios corporales y la imagen tiende a volverse importante y tras ello se crea una identidad en primera instancia y a nivel superficial. En este caso la publicidad aspiracional tendría un rol significativo, ya que serviría de modelo para el target

Por otro lado, podemos conocer los intereses del target respecto a la publicidad según investigaciones realizadas por Ipsos-Apoyo (Universidad de Lima, 2018), la percepción del contenido musical en comerciales en adolescentes es de $90 \%$ (sí creen que la canción influye); en el sector socioeconómico A es de un $95 \%$, mientras que en el B es de $88 \%$. Se añade que la música agradable está dentro de los elementos que más atraen en un comercial de televisión. 
Figura 1.5.1

Percepción del contenido musical en un comercial (\%)

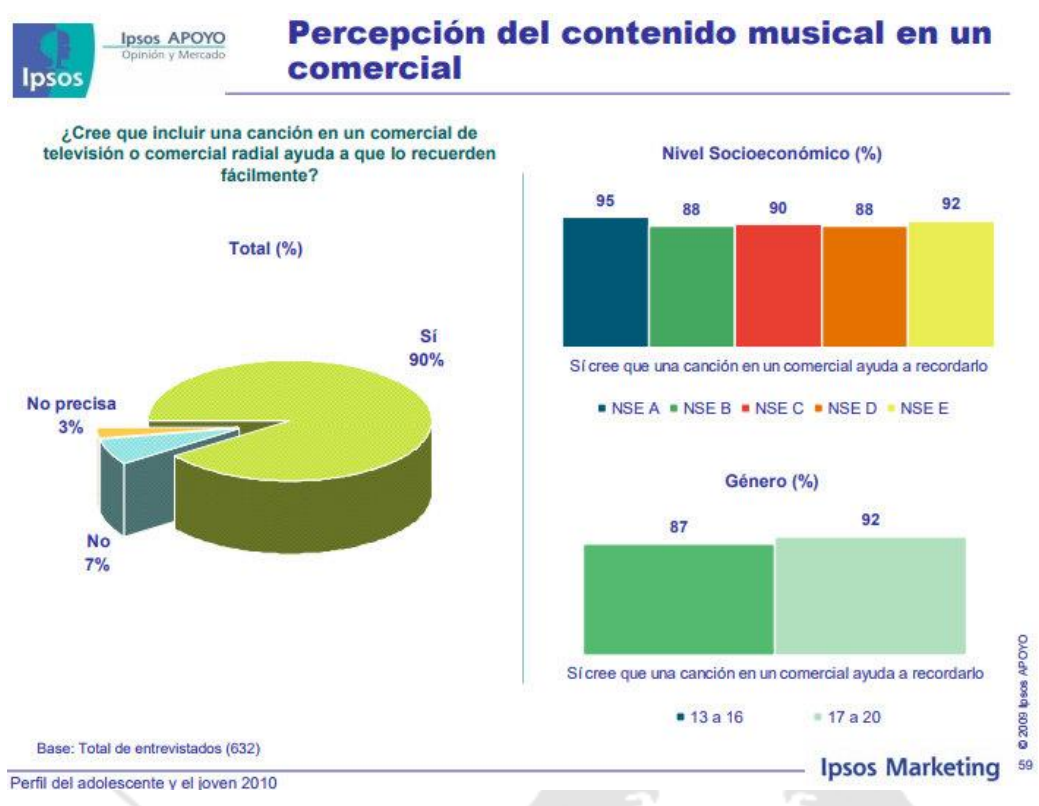

Fuente: Ipsos-Apoyo, (2010). Perfil del adolescente y el joven. Lima metropolitana

\section{Tabla 1.5.2}

Elementos que más atraen en un comercial de televisión (\%)

Las situaciones divertidas, los ambientes naturales y hogareños, así como la música agradable son los elementos que atraen más a los televidentes en un comercial.

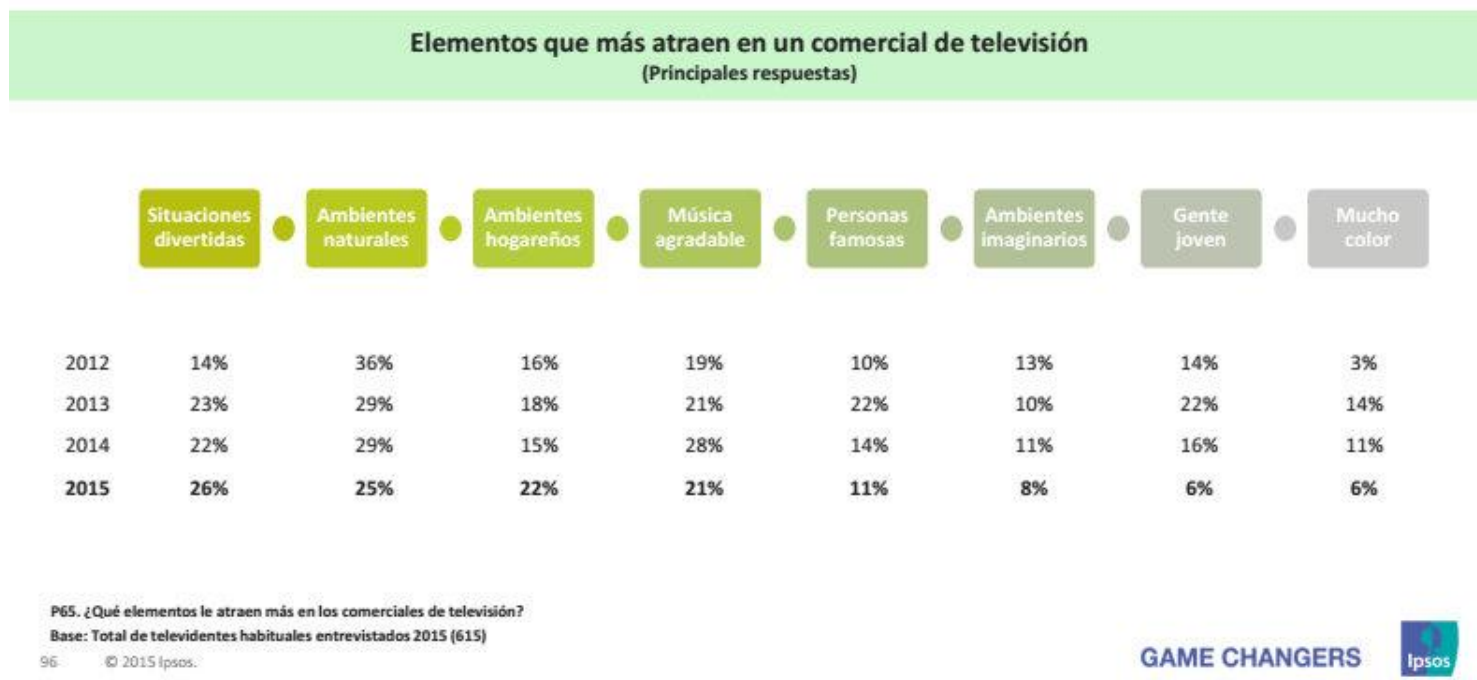

Fuente: Ipsos-Apoyo, (2015). Hábitos usos y actitudes hacia la televisión. Lima metropolitana 


\subsection{El perfume como concepto-producto y su relación con el target}

En términos de productos ofrecidos al consumidor, un perfume es un líquido que posee un aroma o fragancia agradable. En el proceso de elección, el consumidor le otorga diferentes valores y, en consecuencia, determina si es o no de su agrado; la carga que conlleva un determinado olor puede dar distintos significados y sellos a la persona. Según Ernest Dichter (1969) "El olor ayuda a distinguir las cosas deseables de las indeseables" (p. 208).

El perfume, entonces, es un producto que lleva consigo una identidad y un carácter especial que se hacen visibles mediante la publicidad, muchas veces narrativa puesto que es efímero, muchas veces incoloro y no puede "mostrar" un olor gráficamente ni argumentarse con "motivaciones racionales; pues no puede defenderse con este discurso su necesidad" (Rey, 1992, p. 85-86), es por ello que se vale de recursos externos como su empaque y su concepto. La ventaja de la argumentación emocional, según Bassat (1993) es "que cuando estos mensajes llegan a los receptores no generan contra-argumentos, debido a que su forma de persuadir al no apelar a la razón no se puede discutir desde un punto de vista objetivo (p. 67). De aquí que el vínculo con el consumidor pueda ser más emocional e irracional

Respecto al target y el perfume Dichter (1969) añade que: "El tipo de perfume que usa una mujer constituye casi una personalidad secundaria que suplanta un olor biológico básico y original” (p. 208).

Una mujer se siente halagada cuando alguien la reconoce por su perfume. Tal reconocimiento indica que el perfume es individual, acorde con su personalidad. Significa que ella ha comprado algo especial que la distingue del resto, lo cual refleja un buen juicio. La razón psicológica que determina el uso de perfumes no es la de liberarse de olores corporales, sino la de sustituirlos por otros más gratificantes que lograrán la atención favorable de otra gente. (Dichter, 1969, p. 209)

A nivel nacional, Fiorella Solari, gerente de Marketing de Productos de Natura, opina que "en los últimos años el consumidor peruano ha mostrado una característica aspiracional que ha permitido el desarrollo de marcas de lujo y extra lujo que también se encuentran en la perfumería" (cit. en Medina, 4 de septiembre de 2017).

Respecto al target y el poder de decisión de compra en productos de aseo personal; en el nivel socioeconómico A, es de $75 \%$, y en el B, de $77 \%$, donde el $76 \%$ 
son mujeres. Existe información sobre la penetración del uso de fragancias que es del $84 \%$ en el sector A y del $86 \%$ en el B.

Tabla 1.6.1

Poder de decisión de adolescentes y jóvenes (\%)

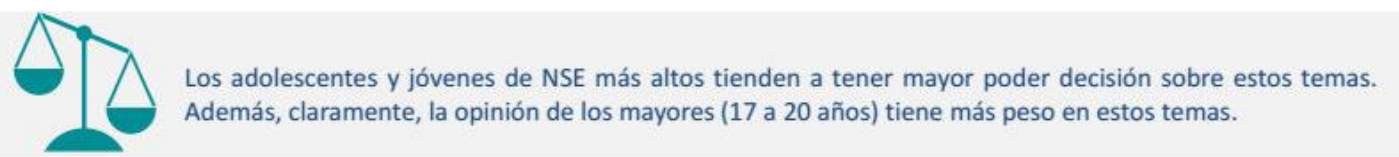

Poder de decisión

\begin{tabular}{|c|c|c|c|c|c|c|c|c|c|c|}
\hline & \multicolumn{10}{|c|}{$\frac{\text { Si decido }}{(\%)}$} \\
\hline & TOTAL & A & B & c & D & E & Hombre & Mujer & $\begin{array}{l}13 \text { a } 16 \\
\text { años }\end{array}$ & $\begin{array}{l}17 \text { a } 20 \\
\text { años }\end{array}$ \\
\hline La compra de ropa & 84 & 94 & 84 & 87 & 90 & 88 & 87 & 89 & 78 & 96 \\
\hline La compra de productos de aseo personal & 74 & 75 & 77 & 74 & 72 & 70 & 72 & 76 & 62 & 84 \\
\hline Los lugares a donde va a divertirse & 73 & 85 & 77 & 77 & 65 & 66 & 79 & 68 & 56 & 87 \\
\hline Restaurantes a los que acude & 45 & 65 & 57 & 41 & 40 & 48 & 42 & 48 & 24 & 63 \\
\hline
\end{tabular}

Fuente: Ipsos-Apoyo, (2010). Perfil del adolescente y el joven. Lima metropolitana

Tabla 1.6.2

Penetración de uso de productos de uso personal (\%)

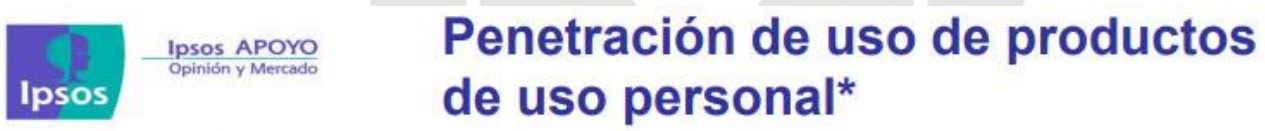

\begin{tabular}{|c|c|c|c|c|c|}
\hline Productos & $\begin{array}{c}\text { Total } \\
\%\end{array}$ & $\begin{array}{c}\text { NSE A } \\
\%\end{array}$ & $\begin{array}{c}\text { NSE B } \\
\%\end{array}$ & $\begin{array}{c}\text { NSE C } \\
\%\end{array}$ & $\begin{array}{c}\text { NSE D } \\
\%\end{array}$ \\
\hline Crema dental & 98 & 100 & 99 & 100 & 100 \\
\hline Cepillo de dientes & 99 & 100 & 99 & 100 & 99 \\
\hline Champư & 99 & 100 & 98 & 99 & 100 \\
\hline Desodocante & 83 & 92 & 92 & 87 & $\pi$ \\
\hline Colonia & 78 & 84 & 86 & 88 & 66 \\
\hline Talco & 50 & 49 & 55 & 54 & 47 \\
\hline Rasuradora / hoja de afeitar & 49 & 54 & 56 & 48 & 45 \\
\hline Reacondicionador & 48 & 52 & 56 & 55 & 38 \\
\hline Pilas & 42 & 42 & 48 & 41 & 46 \\
\hline Enjuage bucal & 37 & 73 & 52 & 40 & 24 \\
\hline Crema para cuerpo y manos & 27 & 41 & 29 & 34 & 17 \\
\hline Hilo dental & 17 & 37 & 27 & 22 & 7 \\
\hline Crema para cuerpo y manos & 27 & 41 & 29 & 34 & 17 \\
\hline Hilo dental & 17 & 37 & 27 & 22 & 7 \\
\hline Tinte para cabello & 15 & 21 & 21 & 19 & 9 \\
\hline $\begin{array}{l}\text { Pastillas contra el dolor de } \\
\text { cabeza }\end{array}$ & 13 & 16 & 11 & 15 & 11 \\
\hline
\end{tabular}

\begin{tabular}{|l|c|c|c|c|c|}
\hline \multicolumn{1}{|c|}{ Productos } & $\begin{array}{c}\text { Total } \\
\%\end{array}$ & $\begin{array}{c}\text { NSE A } \\
\%\end{array}$ & $\begin{array}{c}\text { NSE B } \\
\%\end{array}$ & $\begin{array}{c}\text { NSE C } \\
\%\end{array}$ & $\begin{array}{c}\text { NSE D } \\
\%\end{array}$ \\
\hline Pastillas contra la gripe & 12 & 12 & 7 & 12 & 12 \\
\hline Pastillas contra dolor de estómago & 7 & 7 & 5 & 10 & 3 \\
\hline Cremas contra el acné & 4 & 5 & 3 & 5 & 2 \\
\hline Jarabe para la tos & 4 & 4 & 3 & 2 & 3 \\
\hline Pañales para adulto & 0 & 0 & 0 & 0 & 0 \\
\hline
\end{tabular}

Base: Total de entrevistados: 507 (Hombres: 252 y Mujeres: 255)

Productos de alta penetración Productos de mediana penetración \# Productos de baja penetración Penetración de productos no alimenticios

Fuente: Ipsos-Apoyo, (2010). Perfil del adolescente y el joven. Lima metropolitana 


\subsection{La música y sus principales elementos constitutivos}

La música es un producto de la cultura humana (no hay sociedades sin música) difícil de definir. Philip Ball (2010) dice que "no hay ninguna definición coherente de la música que no excluya alguno de sus aspectos" (p. 23), y cita la del musicólogo Ian Cross, quien sostiene que "las músicas [son] actividades humanas, individuales y sociales de base temporal que consisten en la producción y percepción de sonido" (cit. en Ball, 2010, p. 23). Ball añade que “"sonido organizado' no es una mala descripción operativa" (p. 24). Aunque muchas definiciones de la música incluyen entre sus elementos la necesidad de que sea "disfrutable" o "bella", estas son características subjetivas (casi todo en relación con la música tiende a caer en el subjetivismo pues nuestra experiencia musical es en sí misma subjetiva. Sin embargo, podemos encontrar en ella casi siempre, los siguientes elementos comunes (Borrero-Morales, 2008):

Melodía; es la sucesión de notas específicas de diferentes alturas (tonos) y con una determinada duración.

Ritmo y movimiento; es la sucesión de notas sin altura o entonación específica; una combinación de golpes con diferentes duraciones, ordenados en el tiempo. Dependiendo de su velocidad, estas combinaciones pueden generar estilos, géneros o formas diferentes. Estos también pueden estar clasificados en bpm o golpes por minuto.

Armonía; es la combinación simultánea de bloques sonoros o acordes compuestos por varias notas. En la música occidental (hasta principios del siglo XX), Posee compatibilidad entre notas, dentro de ellas hallamos un dualismo dividido entre la escala mayor y menor. Mediante la escala mayor refleja formas naturales (representa la naturaleza), donde los acordes tienen una conexión o comunión con la naturaleza y nos brindan la sensación de un estado puro. Mientras que la escala menor representa todos los cambios emocionales e imprime emociones variantes en la obra.

Textura; hace referencia a los instrumentos empleados en la pista musical, puesto que cada uno de ellos nos remite a una sensación diferente. Citaremos algunos ejemplos y sus efectos.

- Instrumentos de viento (metales, como las Trompetas): sensación marcial.

- Instrumentos de aliento (maderas, como las flautas): sensaciones relacionadas con el campo y la naturaleza.

- Instrumentos de cuerdas frotadas (violín, viola, cello): efectos emocionales. 
- Cuerdas pulsadas (guitarra, arpa) o percutidas (piano): versatilidad.

- Percusiones: marcan el pulso (ritmo), produciendo diversas sensaciones.

- Voz humana: es el "instrumento" más cercano nosotros; conecta directamente con el oyente, reforzando el sentido musical con el habla.

La combinación de estos (y otros) elementos produce formas (como las que se describen con nombres italianos en la música clásica occidental (adagio, allegro) y estilos o géneros (en la música popular), caracterizados por su velocidad, sus texturas o sus usos de la armonía y la melodía.

El compás, está compuesto por unidades de tiempo, (figuras musicales) organizadas en grupos. Ejemplos: compás de 3/4, 4/4, etc.

El estilo, contempla lo que son determinadas características en obras musicales para poder clasificarlas. Ejemplo: Pop, rock, jazz, hip hop, reggae, soul etc.

La afinación, referida a la nota bajo la cual está construida una obra musical. Ejemplo: Mi, La, Do, etc. 


\section{CAPÍTULO II: METODOLOGÍA}

\subsection{Pregunta principal de investigación}

La pregunta que ha guiado nuestra investigación es la siguiente: ¿Cómo tiene efecto, en el significado de apropiación que las adolescentes hacen de spots publicitarios de perfumes, el valor añadido de la música en la sincresis de los fenómenos sonoro y visual?

\subsection{Objetivo general}

Nuestra investigación busca conocer los efectos del valor añadido de la música en la construcción de significados de apropiación de spots publicitarios de perfumes en mujeres adolescentes de Lima Metropolitana.

\subsection{Objetivos específicos}

Nuestros objetivos específicos son los siguientes:

- Analizar la relación entre imagen y música en spots publicitarios desde las perspectivas de mujeres adolescentes.

- Reconocer tipos de emociones según el público.

- Averiguar si se genera apropiación de la música o si esta afecta el proceso de aceptación de la publicidad de perfumes por parte de las adolescentes.

\subsection{Descripción de la investigación}

Nuestra investigación es de tipo cualitativo, puesto que se recoge información sobre las vivencias de las participantes entrevistadas, quienes en sus palabras dan a entender sus opiniones. Sin embargo, la investigación tiene una dimensión cuantitativa pues la información recopilada a través de las entrevistas con las participantes se compara y se analiza estadísticamente para hallar semejanzas y diferencias. De esta manera, se realizaron veinte entrevistas a mujeres jóvenes del sector socioeconómico señalado en el mes de Noviembre del 2017 en la Universidad de Lima, se selecciona esta muestra pues es posible decir que conlleva un grupo determinado de jóvenes que tienen un consumo masivo de medios de comunicación muchas horas a las semana y tienden a 
vivir el proceso de la sincresis sin darse cuenta a través de publicidad televisiva e internet, es decir que es un caso real (detallado en el capítulo I).

El análisis de entrevistas nos ha permitido contrastar opiniones y determinar un patrón recurrente mediante la modificación de la variable "música" en dos casos publicitarios representativos, mostrados a una muestra del target en cuestión.

Para completar la investigación consideramos la opinión de expertos siguiendo el método Delphi:

Técnica de obtención de información, basada en la consulta a expertos de un área, con el fin de obtener la opinión de consenso más fiable del grupo consultado. Estos expertos son sometidos individualmente a una serie de cuestionarios en profundidad que se intercalan con retroalimentación de lo expresado por el grupo y que, partiendo de una exploración abierta, tras las sucesivas devoluciones, producen una opinión que representa al grupo. (Reguant-Álvarez y Torrado-Fonseca, 2016, p. 88)

Bajo este método se realizaron cinco entrevistas a productores musicales y músicos del rubro publicitario para tener un mejor acercamiento al tema desde la perspectiva del creador musical de manera complementaria y una intervención a una profesional de marketing con experiencia en una empresa extranjera líder en productos de cuidado personal, L' Oréal.

Por otro lado, también se ha obtenido un resultado analítico a nivel musical, a través de la descomposición de cada pista en sus principales elementos: melodía, armonía, movimiento, compás, textura, estilo y afinación, para observar más detalladamente las preferencias y diferencias manifestadas por las entrevistadas a nivel técnico.

Es importante tener en cuenta que se seleccionó el rubro de perfumes por la gran carga conceptual que conllevan. "La gran mayoría de los anuncios de perfumes no hacen ningún esfuerzo para describir los aromas que están promoviendo" (Richard, 1992, p.45).

Seleccionamos dos spots representativos de Latinoamérica y Europa. Los spots seleccionados fueron:

- "Humor!", perfume de la marca brasileña Natura, con música creada para el comercial. El spot, de 30 segundos de duración, muestra a un par de chicas en situaciones de tiempo libre y diversión.

- "Amor amor", de la marca francesa Cacharel, con música de la banda belga Hooverphonic (la canción "Gravity” de su álbum Reflection, 2013). El spot, 
de 45 segundos de duración, muestra a una pareja joven (una chica y un chico) en situación de aventura que culmina con un beso.

En cada uno de los casos se mostraron a las participantes dos diferentes videos en un orden predefinido (en primer lugar el spot con pista de música modificada por nosotros y después el original), omitiendo cuál era el original, para apreciar sus opiniones respecto a la música. Para modificar la pista de música de los spots utilizamos música de archivo (Jamendo Music, s. f.) reproducida en bucle (loop o repeticiones de una sección corta), la cual es usada muchas veces para fondos publicitarios. Las pistas de libre uso seleccionadas fueron "Beyond borders of inspiration" (para Natura) y "Story of one success" (para Cacharel)

Los spots con pistas modificadas fueron identificados con la letra "A". Pueden verse en Youtube siguiendo los enlaces entre paréntesis y consultarse las partituras de la música en el anexo 1:

- Spot "Humor!" de Natura A (https://www.youtube.com/watch?v=yzaxLKJnaq0). - Spot "Amor amor" de Cacharel A: (https://www.youtube.com/watch?v=8IQbuJPw4wg).

Los spots originales ( $\sin$ modificación de audio), se identificaron con la letra "B" al final. Las partituras pueden consultarse en el anexo 2:

- Spot "Humor!" de Natura tra (https://www.youtube.com/watch?v=PYbmSTxzVcU).

- Spot "Amor amor" de Cacharel B: (https://www.youtube.com/watch?v=6d7hdVEhg0M),

\subsubsection{Muestra de participantes}

Ambos pares de spots fueron presentados a una muestra conformada por 20 mujeres adolescentes (entre 14 y 20 años de edad) de Lima Metropolitana, pertenecientes a los niveles socioeconómicos A y B.

Esta muestra se concentra en mujeres adolescentes con poder económico pues las marcas poseen precios elevados y se dirigen targets con estas características. 


\subsubsection{Muestra de expertos}

1. Karin Zielinski: Productora musical en Stereomonkey (Casa de Diseño sonoro)

2. Ricardo Tafur: Productor musical en "Barracuda estudio"

3. Mauricio Chau: Productor musical independiente y músico en "Los terapeutas del ritmo“

4. Gonzalo polar: Productor en estudio "La sonora"

5. Luche Bedoya: Productora musical en "Farmacia, casa de audio publicitario".

6. Zonia palacios: Jefa del área de Marketing de L'Oréal en Perú

\subsubsection{Técnica e instrumento de recolección de datos}

El cuestionario al que las adolescentes estarán expuestas por medio de una entrevista en los dos casos cuenta, en primera instancia, con preguntas que pueden ser clasificadas bajo un común denominador correspondiente a los siguientes ítems:

- Emociones: ayudan a reconocer e identificar las impresiones del target en cada spot.

- Nivel socioeconómico: relevante para comprender la ubicación que el target le asigna en la sociedad respecto a economía y educación.

- Precio: Nos ayuda a conocer el valor en soles que el target le otorga y saber cómo está posicionado en su mente.

- Estilo de vida: Relacionado con la idiosincrasia que el target le atribuye al producto en el spot. A través de ello podemos conocer su perfil.

- Edad: Importante para saber si este el tipo de spot es compatible con los pares del target.

Finalmente concluye con una pregunta abierta:

- Interpretación acerca del mensaje: Ayuda a entender lo que el target opina del spot en su totalidad y lo que este le transmite en sus propias palabras.

Asimismo, el cuestionario para productores engloba ítems referentes al trabajo de preproducción para spots publicitarios a nivel de audio, así como su opinión respecto a la importancia de la música en este sector. Este marco nos ayuda a tener una mejor visión en cuanto a la mirada del creador y su proceso de trabajo. A continuación enunciamos los temas de las entrevistas: 
- Factores fundamentales en la preproducción musical para un spot publicitario.

- Medida en que afecta la música a un spot publicitario y factores que condicionan este efecto.

- Manera en que se trabaja un producto conceptual (por ejemplo, perfumes/olores) al momento de crear una pista para su spot.

- Criterios para la elección de un género y estilo en un spot publicitario.

- Criterios para usar música de archivo.

- La elección entre adaptar y crear.

- La importancia de la música en la publicidad. 


\section{CAPÍTULO III: RESULTADOS}

\subsection{Presentación de las marcas}

Natura es una marca de productos de belleza y cuidado personal de origen brasileño, creada en 1969 por el empresario y economista Luiz Seabra. Actualmente está presente en siete países de América Latina y en Francia. En el Perú cuenta con una filial en Lima Metropolitana, diferentes puntos de venta (tiendas físicas) y una estrategia de ventas a través de consultoras.

La publicidad de Natura tiene presencia en televisión abierta y redes sociales, y utiliza una página web con extensión específica para el Perú. En cuanto a la personalidad de marca, Natura refleja la fuerza de la naturaleza como concepto principal; la importancia del bienestar del ser humano y su diversidad (sexual, racial, cultural), la frescura, la ecología, la biodiversidad botánica brasileña y la cultura de sostenibilidad.

El perfume de Natura que hemos elegido, "Humor!", se describe técnicamente, según la página oficial de la marca (Meu Primeiro Humor - Fragancia Femenina, s. f.), como "Camino olfativo frutal, sensual, pera". En el spot se usa una gama de colores cálidos (amarillo, verde y celeste) que remiten a la playa y a la naturaleza, dejando el rojo solo para el perfume.

Por su parte, Cacharel es una marca de perfumes, ropa y accesorios, de origen francés, fundada en 1962 por el empresario Jean Bousque. Se trata de una marca mundialmente conocida. En Lima sus productos se comercializan a través de tiendas de departamentos.

Su publicidad está presente en televisión abierta, redes sociales y su página oficial en internet. Su personalidad está ligada a la feminidad, el refinamiento, la ligereza, la jovialidad, y por lo general usa una gama de colores brillantes en sus productos.

La fragancia elegida para nuestra investigación, “Amor amor”, se describe de la siguiente manera: “Oda al más puro de los sentimientos, la fragancia Amor Amor te hace querer amar un poco, mucho, apasionadamente... El perfume Amor Amor transforma a las chicas en seductoras intrépidas" (Cacharel, s. f.). El aroma se describe 
con diversos conceptos que remiten a lo floral y frutal. El spot se caracteriza por estar en escala de grises, mostrando el frasco rojo solo al finalizar el video.

\subsection{Resultados de entrevistas a participantes}

A continuación expondremos los resultados obtenidos luego de la aplicación de los instrumentos previamente descritos sin interpretaciones o juicios de valor. En esta fase damos a conocer la respuesta del target ante dos diferentes pistas musicales para un mismo comercial en los dos casos representativos ya mencionados. El target está comprendido por alumnas de la Universidad de Lima de nivel socioeconómico A/B, a las cuales se las invitó a participar de manera voluntaria mediante la observación de los spots en un aula, teniendo como soporte un proyector y sin previo aviso de cuales eran los comerciales originales para tener un mejor acercamiento a sus apreciaciones. A las participantes se les dio a entender, como marco de la entrevista, que el objetivo era su apreciación global a acerca de determinados spots. No se les especificó nuestra intención de poner énfasis en la música en este estudio, para evitar la dirección de su atención a este aspecto, sino buscando la mirada natural del target.

A continuación se presentan los resultados de las preguntas realizadas a las participantes de forma gráfica. Es importante recordar que las respuestas no son únicas, es decir que existe más de un atributo, el cual puede ser repetido en varias ocasiones y por muchas participantes. 


\subsubsection{Análisis cuantitativo de spot natura A (modificado)}

Gráfico 3.2.1.1

Emociones que transmite el spot

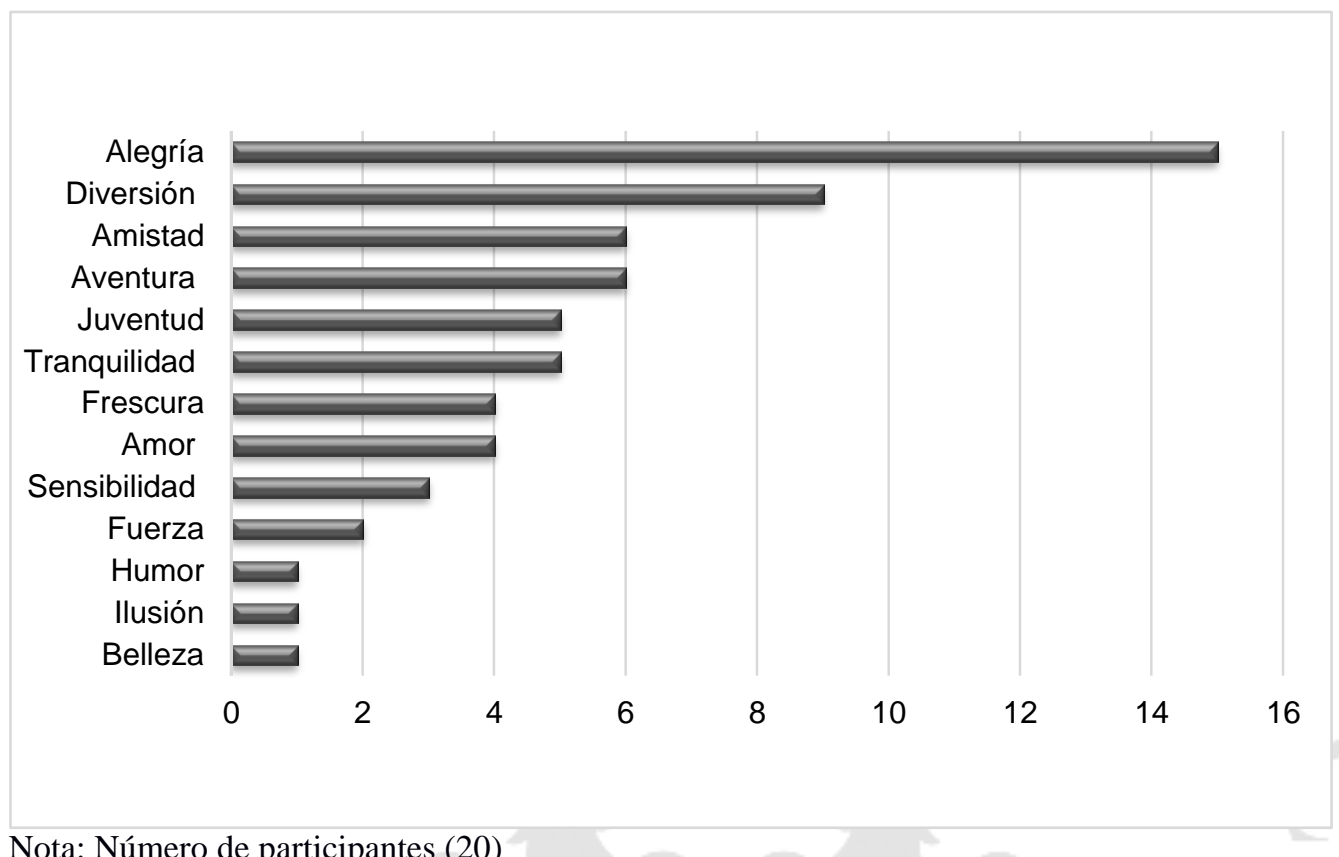

Nota: Número de participantes (20)

Fuente: Elaboración propia

El $75 \%$ de las participantes asignaron un sentido de "alegría" al spot Natura A

(Gráfico 3.2.1.1) 
Gráfico 3.2.1.2

Nivel socioeconómico que le asignaría al spot

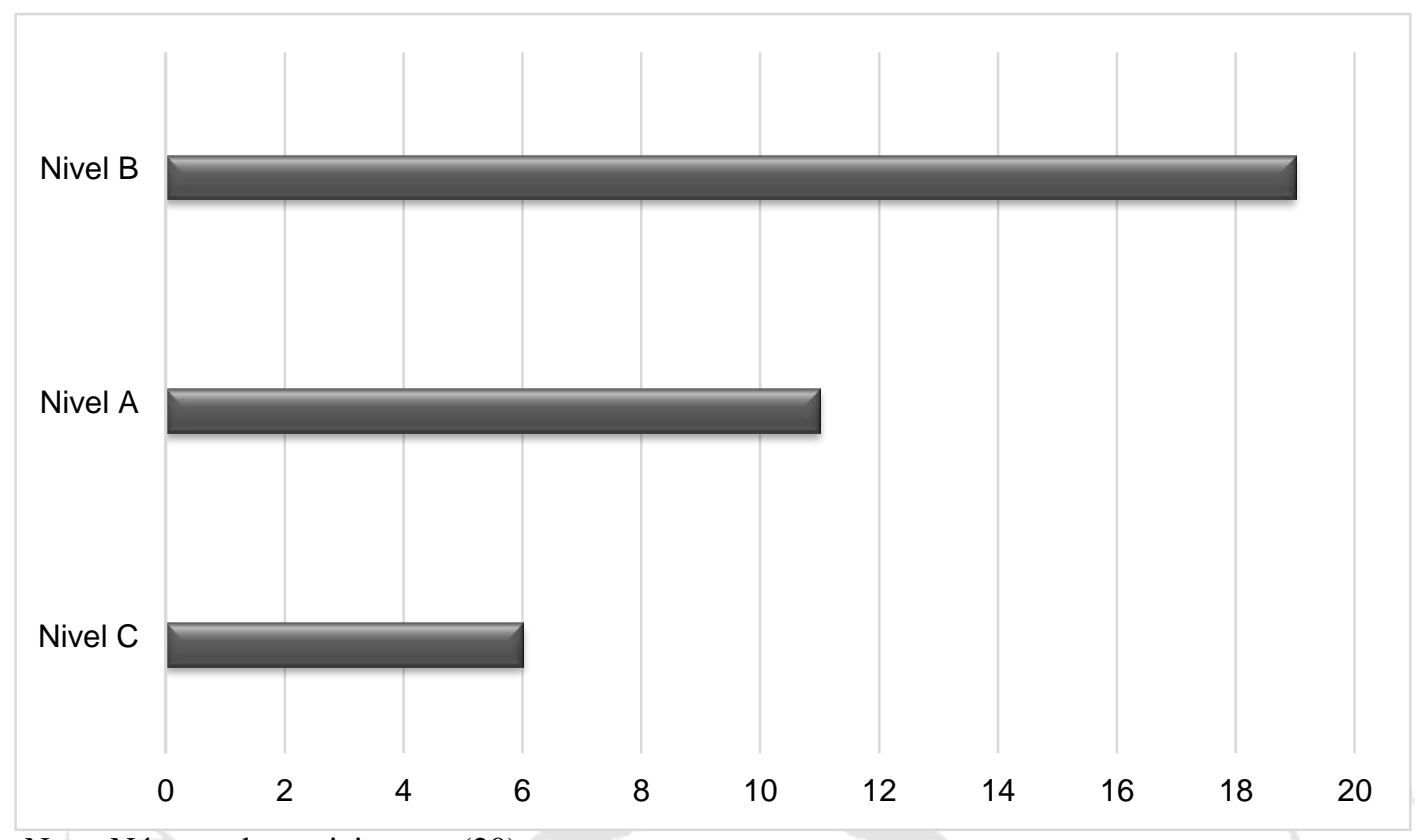

Nota: Número de participantes (20)

Fuente: Elaboración propia

El 95\% de las participantes relacionaron al spot con el nivel socioeconómico B y en segundo plano con 55\% el A (Gráfico 3.2.1.2)

Gráfico 3.2.1.3

Precio que le asigna al producto en soles

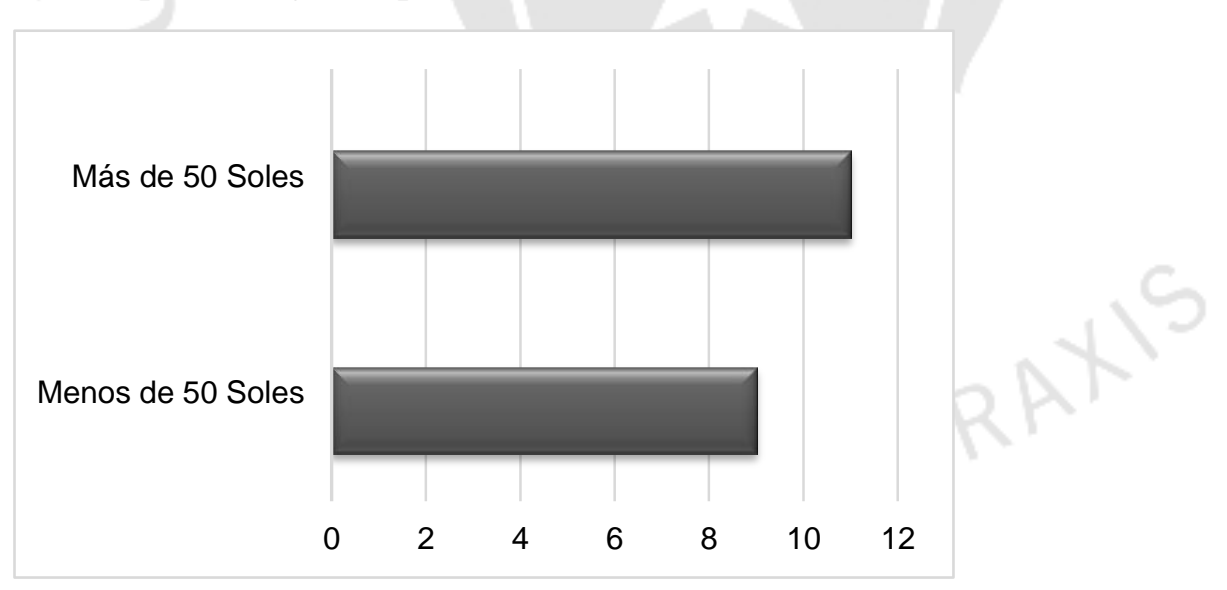

Nota: Número de participantes (20)

Fuente: Elaboración propia

El 55\% de las participantes piensa que el producto podría costar entre 50 y 100 soles. (Gráfico 3.2.1.3) 
Gráfico 3.2.1.4

Edad con que se relaciona el spot

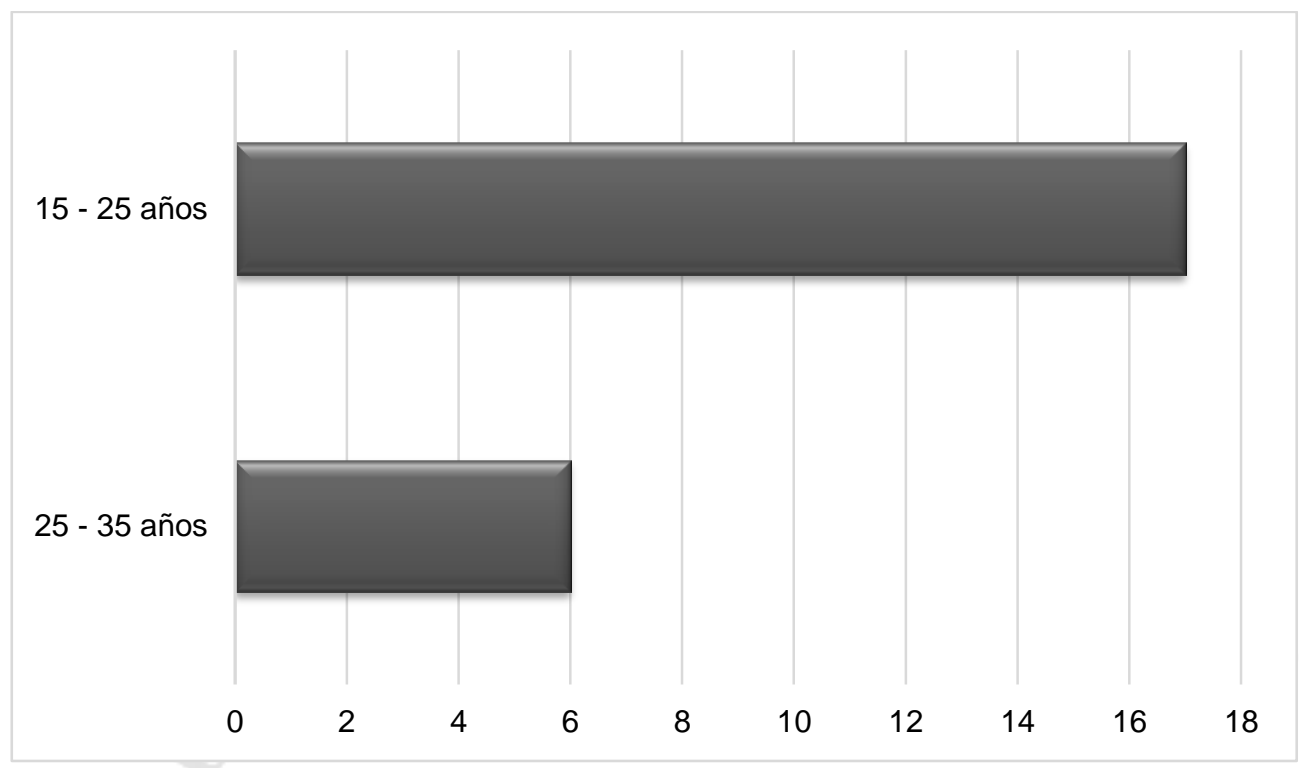

Nota: Número de participantes (20)

Fuente: Elaboración propia

El 85\% de las participantes relaciona el spot con un rango de edad de 15 a 25 años de edad. (Gráfico 3.2.1.4)

Gráfico 3.2.1.5

Estilo de vida reflejado en el spot

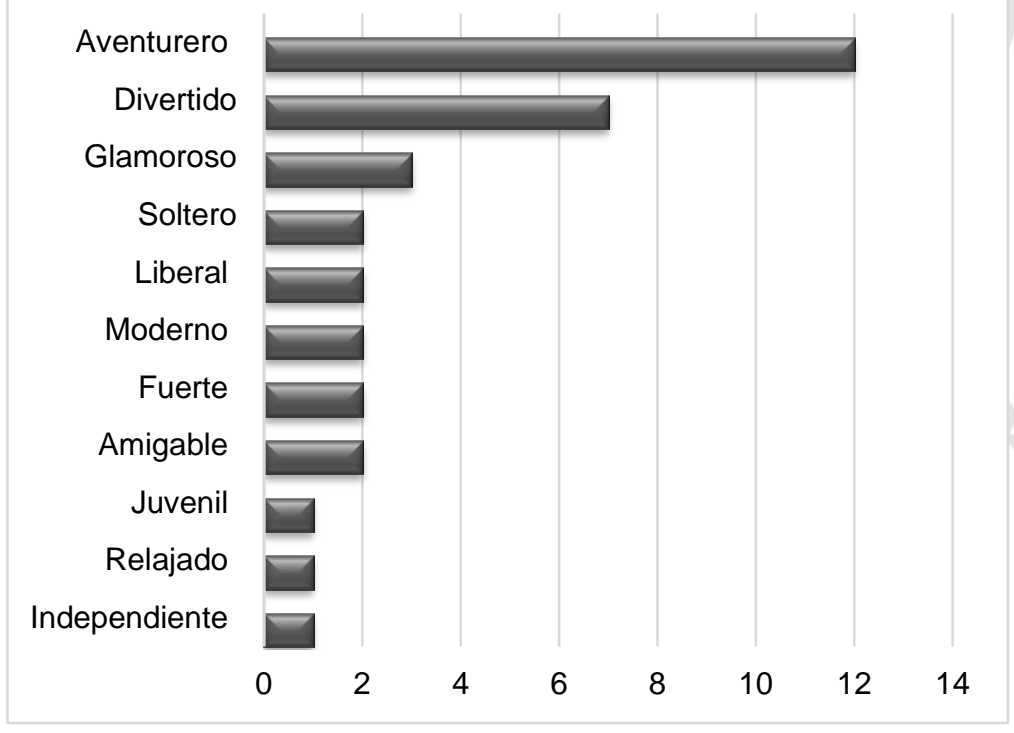

Nota: Número de participantes (20)

Fuente: Elaboración propia

El 60\% de las participantes cree que el estilo de vida es Aventurero. (Gráfico

\subsubsection{5)}


En la siguiente lista se detallarán las opiniones de las participantes en sus propias palabras a acerca de lo que el spot Natura A les comunica en lo que respecta a audio e imagen. En el caso de la pregunta “¿Qué le transmite el mensaje?”, se obtuvieron los siguientes resultados:

- "El perfume se adecua a la personalidad o estado de ánimo".

- "Ser quien eres sin miedo".

- "Perfume fresco de olores cítricos para jóvenes".

- "Producto que acompaña en todo momento de diversión y aventura".

- "Usando el perfume te acompaña al tener todas estas experiencias nuevas y divertidas".

- "Vivir la vida con humor y por eso el producto natura contribuye a eso".

- "El perfume es para divertirse, tomar las riendas de tu vida".

- "Ser femenina y vivirlo".

- "La belleza está en cosas que te hacen sonreír".

- "Colonia para cualquier ocasión y tiene un aroma natural y suave".

- "Con esto te puedes sentir libre, activa y divertida".

- "Vivir cada momento".

- "Te hace sentir bella, sin violencia"

- "Te da una actitud despreocupada, femenina y divertida".

- "Vive tu vida y sé feliz".

- "Es un buen regalo". 


\subsubsection{Análisis cuantitativo de spot natura B (original)}

Gráfico 3.2.2.1

Emociones que le transmite el spot

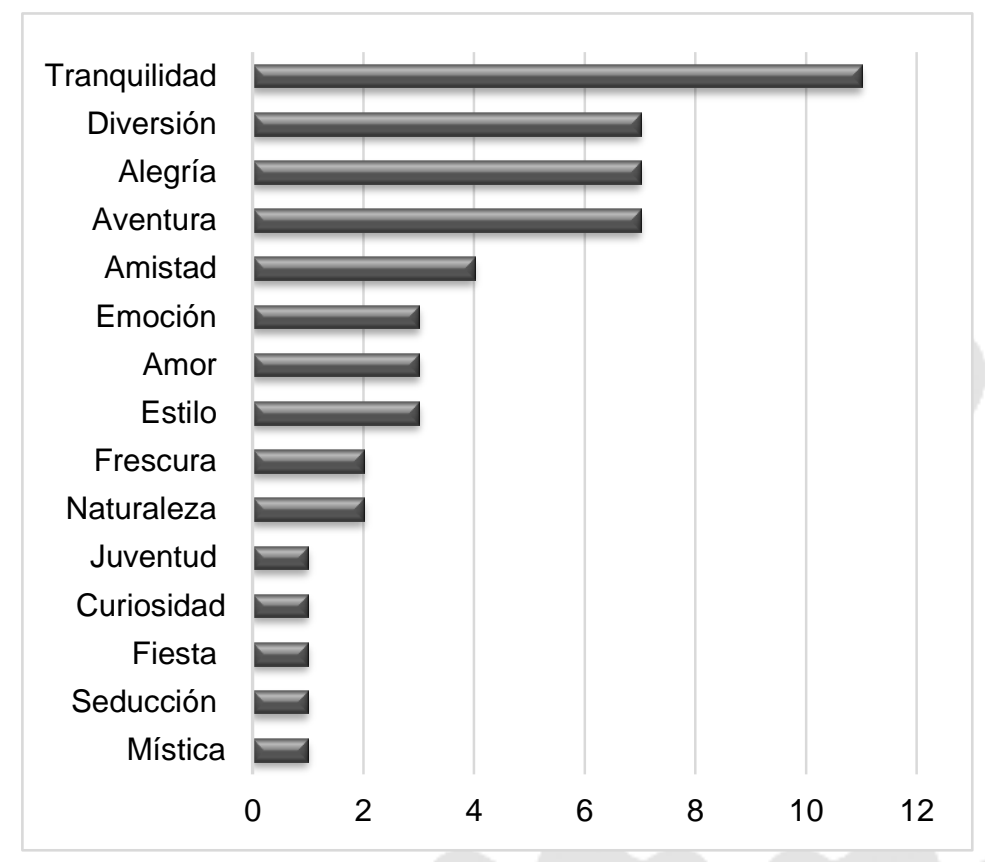

Nota: Número de participantes (20)

Fuente: Elaboración propia

E1 55\% asigna un sentido de tranquilidad al spot Natura B (Gráfico 3.2.2.1)

Gráfico 3.2.2.2

Nivel socioeconómico que le asigna al spot

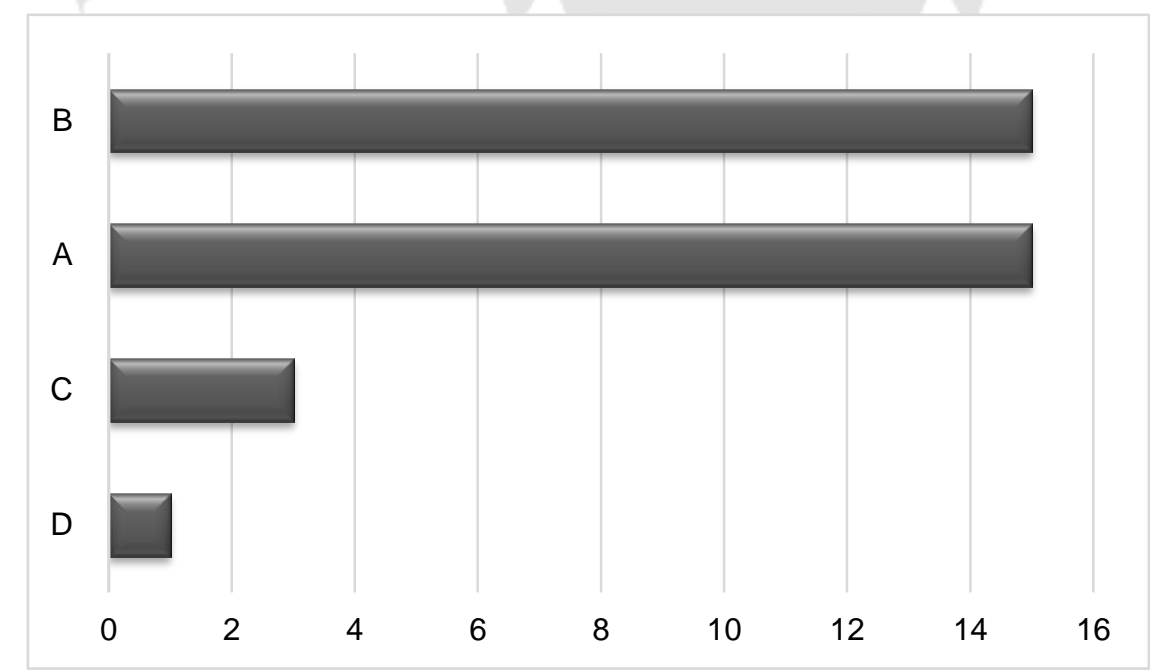

Nota: Número de participantes (20)

Fuente: Elaboración propia 
El 75\% relaciona el spot con los niveles socioeconómico A y B de igual manera.

(Gráfico 3.2.2.2)

\section{Gráfico 3.2.2.3}

Precio que le asigna en soles al producto

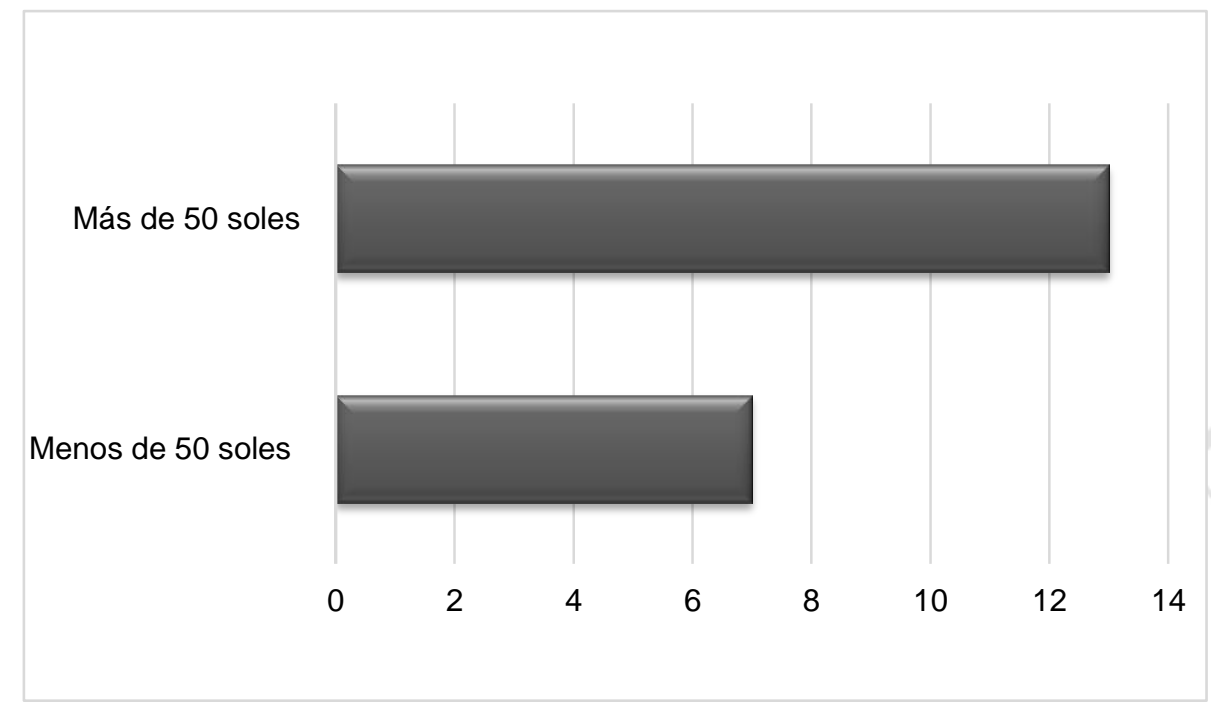

Nota: Número de participantes (20)

Fuente: Elaboración propia

El 65\% de las participantes asigno un rango de precio de 50 a 100 soles al producto. (Gráfico 3.2.2.3)

\section{Gráfico 3.2.2.4}

Edad que relaciona al spot

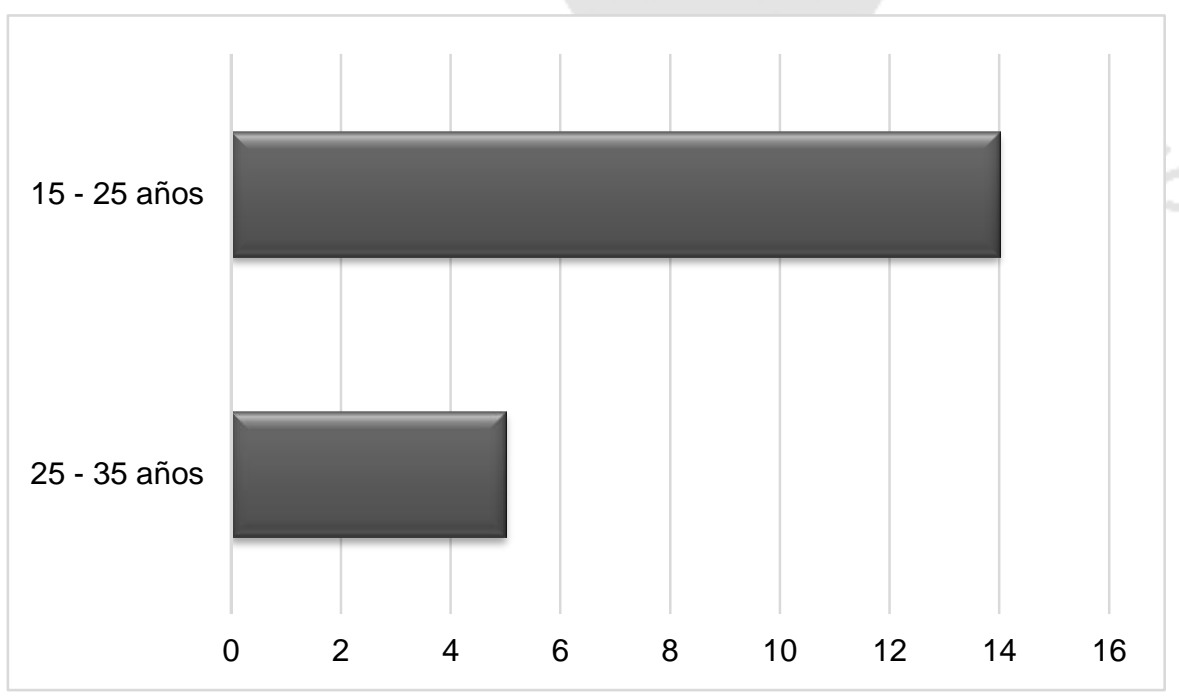

Nota: Número de participantes (20)

Fuente: Elaboración propia 
El 70\% de las participantes relaciono el spot con un rango de 15 a 25 años de edad. (Gráfico 3.2.2.4)

\section{Gráfico 3.2.2.5}

Estilo de vida reflejado en el spot

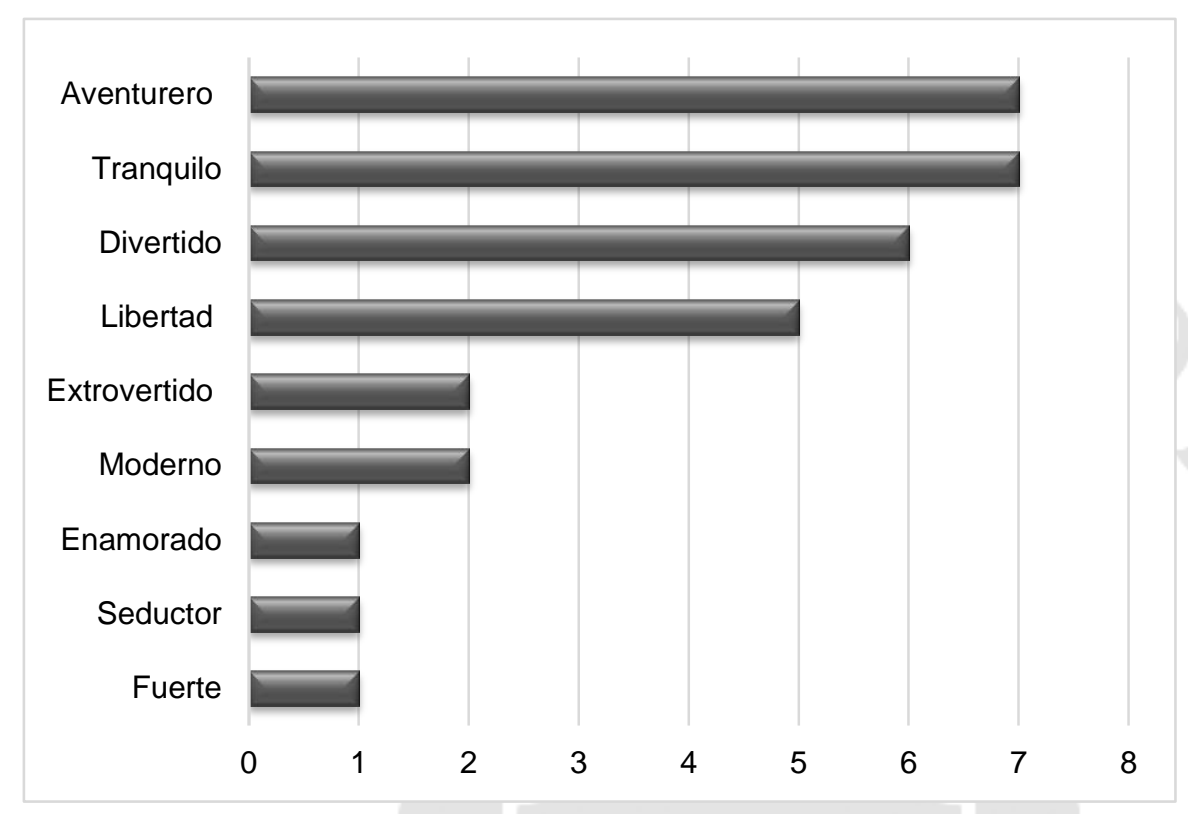

Nota: Número de participantes (20)

Fuente: Elaboración propia

El 35\% de las participantes relaciono el estilo de vida aventurero con el spot, mientras que otro $35 \%$ con uno tranquilo. (Gráfico 3.2.2.5)

Para el spot Natura B, en la pregunta “¿Qué le transmite el mensaje?" se obtuvieron las siguientes respuestas:

- "Acompaña tus aventuras y momentos felices".

- "Haz lo que te haga feliz".

- "El perfume es el regalo perfecto para una amiga siempre".

- "No violencia, producto que nos hace sentir bellas".

- "Lleva una vida cool, llena de aventuras".

- "Para mujeres seguras que no temen expresar su manera de ser".

- No lo tiene claro.

- "El perfume es un buen regalo para Navidad, lo importante es pasar el momento juntas".

- "Que es para señoras". 
- "La belleza de una joven reside en las aventuras, Natura es para jóvenes que aman vivir al máximo".

- "Olor dulce para una mujer intrépida".

- "Refrescante, le puede quedar a cualquiera".

- "Diversión, disfrute entre amigas".

- "Belleza, aprovecha el momento, sé feliz".

- "Para cada experiencia de nuestra vida está Natura".

- "El producto va con las distintas emociones mostradas en el spot".

- "Ser feliz siendo tú".

- "En un nuevo perfume con olores frescos y cítricos".

- "Más tranquilidad, que el producto es ligero y fresco".

\subsubsection{Análisis cuantitativo de spot Cacharel A (modificado)}

Gráfico 3.2.3.1

Emociones que le transmite el spot

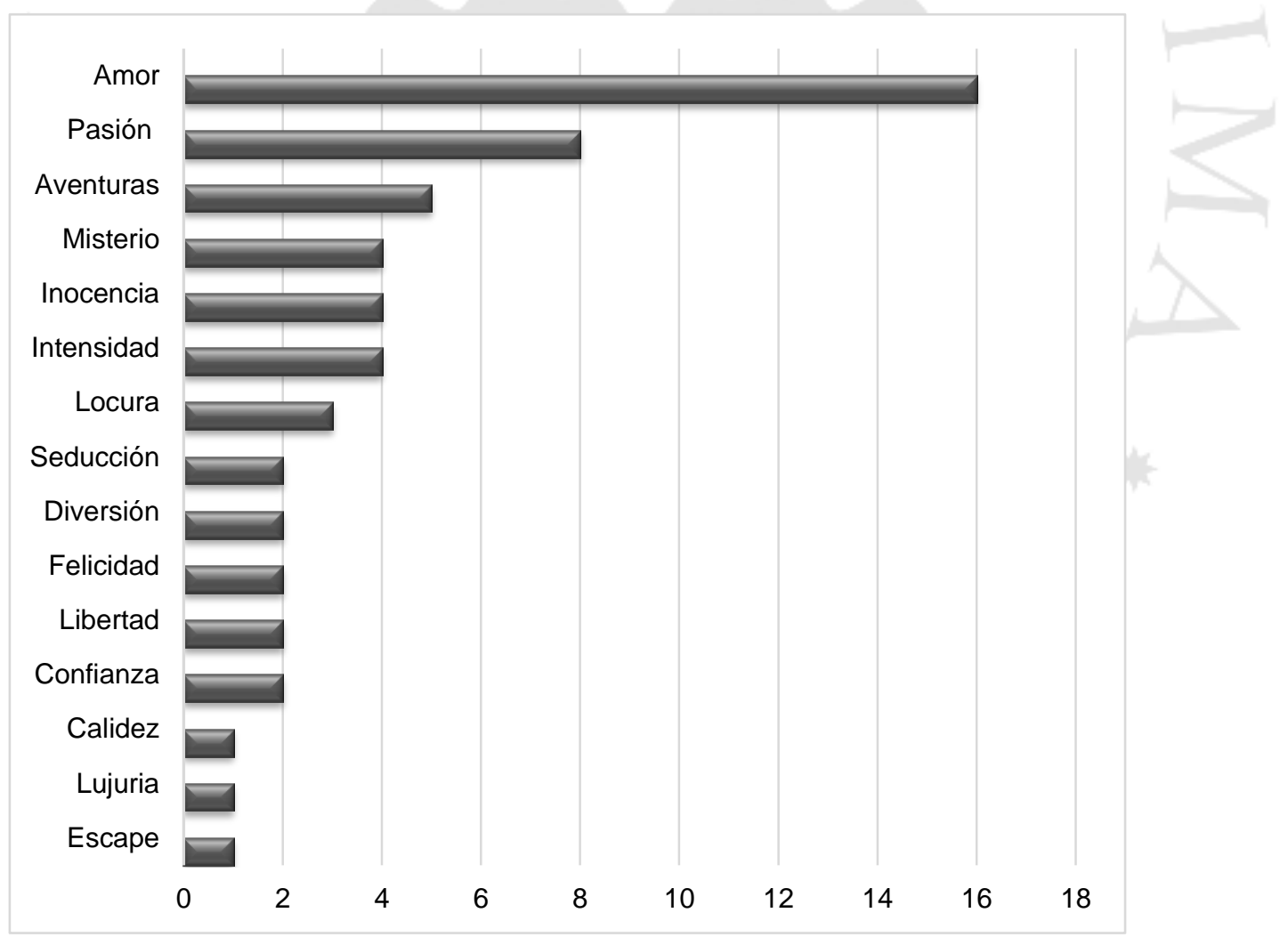

Nota: Número de participantes (20)

Fuente: Elaboración propia

El 80\% de las participantes asigna el sentido de amor al spot (Gráfico 3.2.3.1) 


\section{Gráfico 3.2.3.2}

Nivel socioeconómico que le asignaría al spot

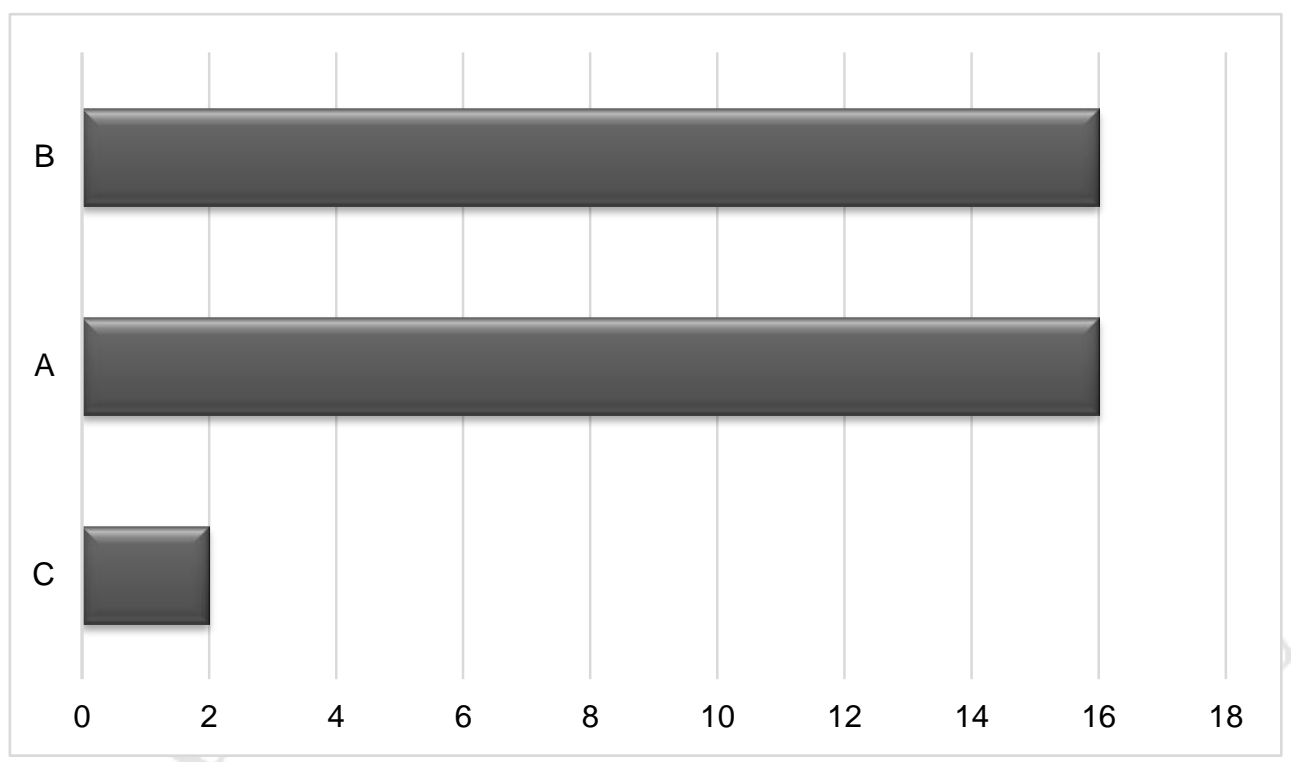

Nota: Número de participantes (20)

Fuente: Elaboración propia

El 80\% de las participantes relaciona el spot con los niveles socioeconómicos A

y B al mismo tiempo. (Gráfico 3.2.3.2)

\section{Gráfico 3.2.3.3}

Precio que le asigna en soles al producto

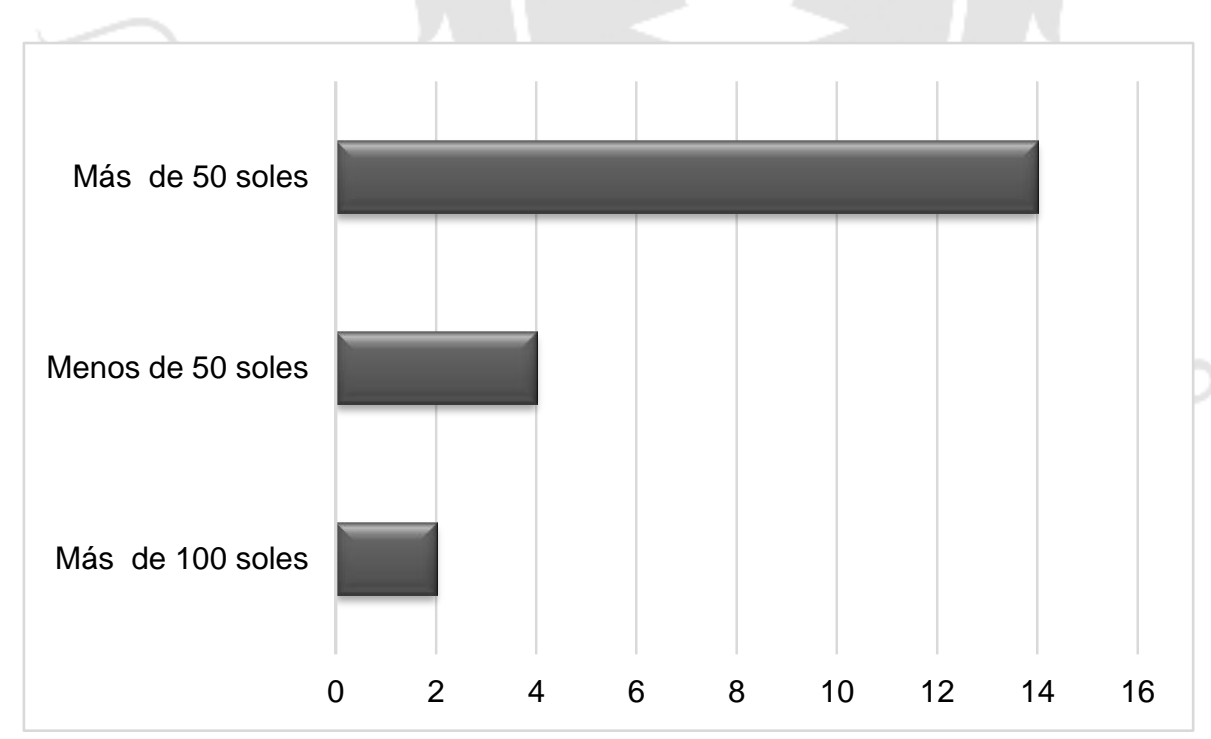

Nota: Número de participantes (20)

Fuente: Elaboración propia

El 70\% de las participantes asignaron el rango de precio de 50 a 100 soles en el producto. (Gráfico 3.2.3.3) 
Gráfico 3.2.3.4

Edad con que relaciona el spot

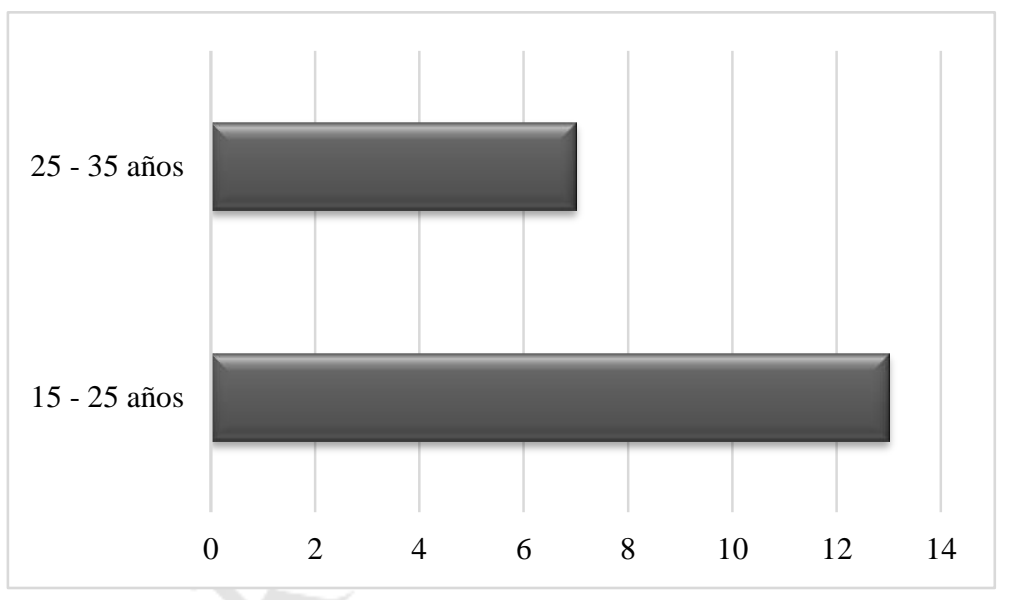

Nota: Número de participantes (20)

Fuente: Elaboración propia

El $65 \%$ de las participantes relaciono el spot con un rango de edad de 15 a 25 años. (Gráfico 3.2.3.4)

Gráfico 3.2.3.5

Estilo de vida reflejado en el spot

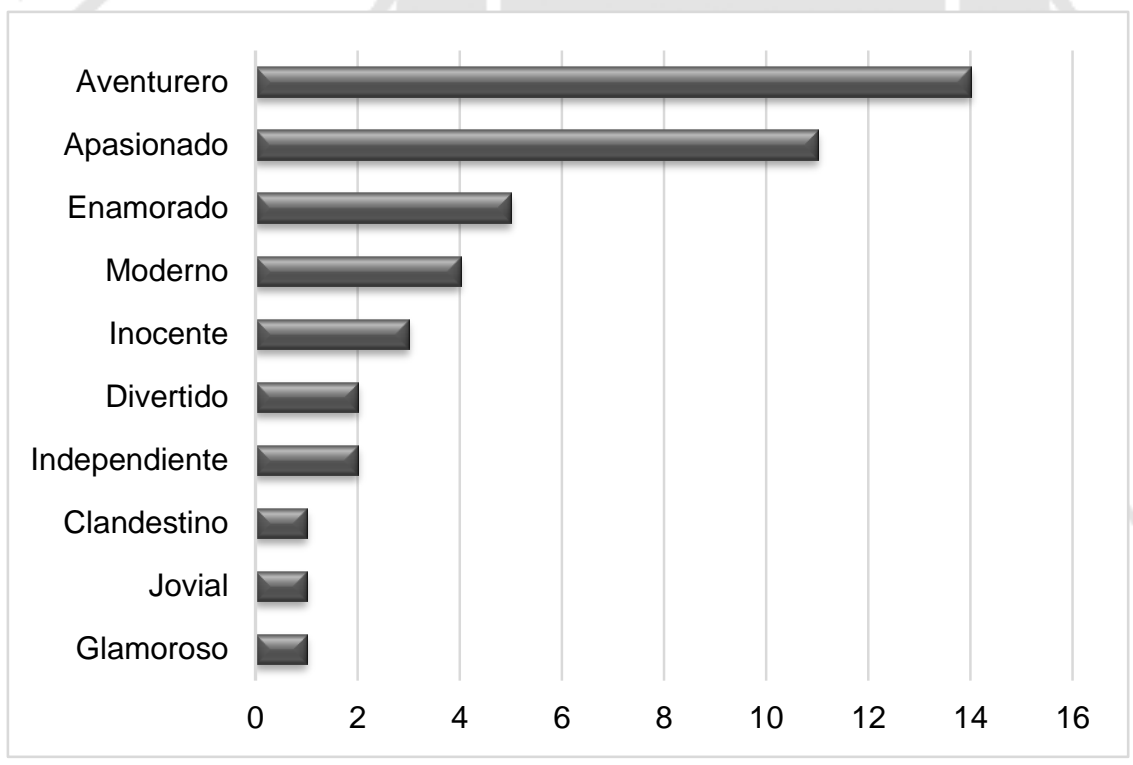

Nota: Número de participantes (20)

Fuente: Elaboración propia

El $70 \%$ de las participantes relaciono el estilo de vida aventurero al spot, mientras que 55\% al apasionado. (Gráfico 3.2.3.5) 
En el spot Cacharel A, la pregunta “¿Qué le transmite el mensaje?” tuvo los siguientes comentarios:

- "Al dejar de lado los miedos puedes amar mejor; no es bueno aferrarse a que vas a estar solo, vive más".

- "Atreverse y no tener miedo".

- "Relacionado al concepto del amor, un amor más despreocupado y divertido".

- "Encuentra el amor y ten una vida llena de felicidad".

- "Arriesgarse en el amor porque te sorprenderá siempre".

- "El perfume te abre nuevos caminos, descubres nuevas cosas, descubres el amor".

- "Presentación de un nuevo perfume que tiene olores florales y dulces".

- "El primer amor está lleno de emociones fuertes y de deseos por experimentar".

- "No lo tengo muy claro, creo que el mensaje te dice que te arriesgues por ese amor".

- "Te ayuda a desatar tus impulsos, puedes tener el control sin temores".

- "Gracias al perfume la pareja puede llegar a un estado al inicio desconocido, pero luego pasional".

- "La complicidad del amor".

- "La emoción que representa el amor".

- “Amor".

- "El perfume es el que ilumina esa oscuridad o miedo que no permitía que ambos demostraran su amor apasionado".

- "Despiertan el amor juvenil".

- "Este perfume representa el amor con su olor".

- "Perfume que atrae".

- "La esencia del perfume es tan profunda como el amor entre dos personas, además de su ligereza". 


\subsubsection{Análisis cuantitativo de spot Cacharel B (original)}

Gráfico 3.2.4.1

Emociones que le transmite el spot

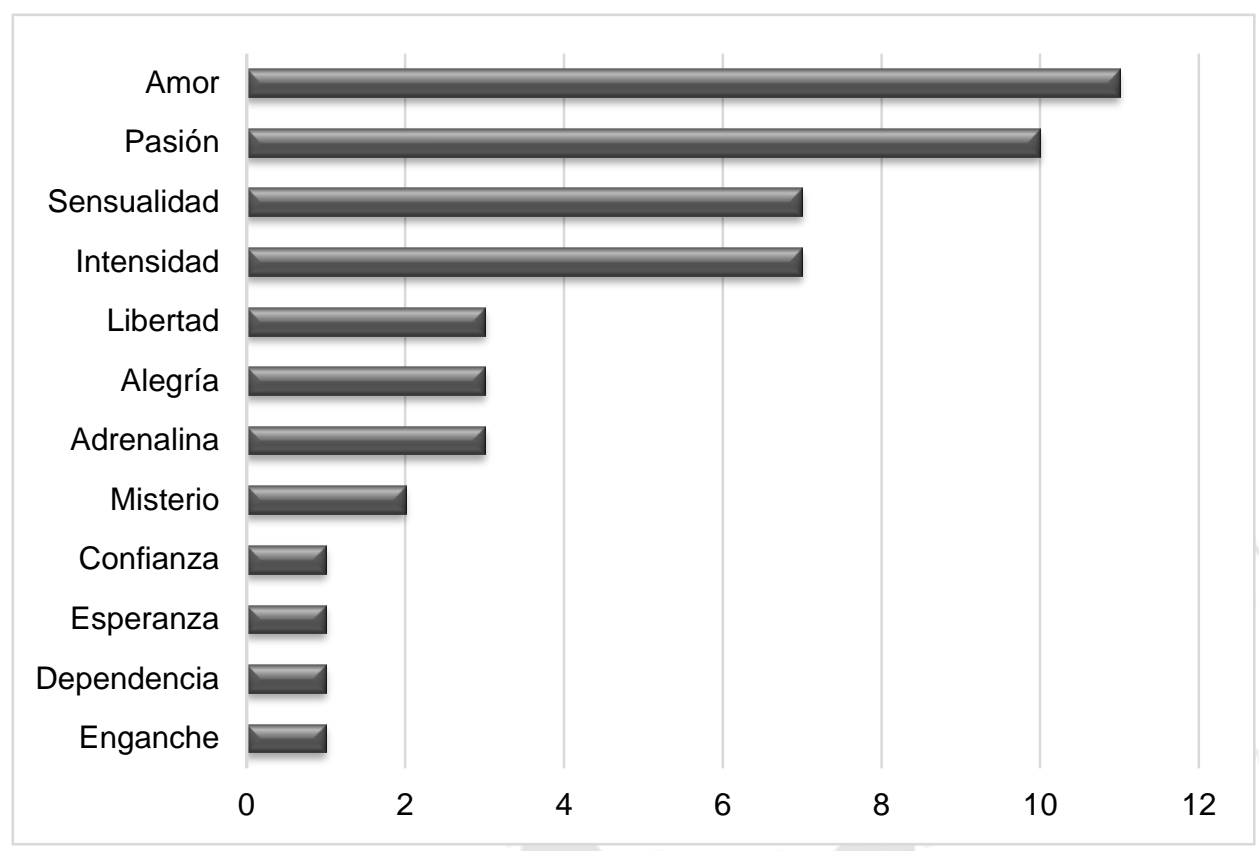

Nota: Número de participantes (20)

Fuente: Elaboración propia

El 55\% de las participantes asignaron el sentido de amor al spot, mientras que en segundo plano un 50\% pasión. (Gráfico 3.2.4.1)

Gráfico 3.2.4.2

Nivel socioeconómico que le asigna al spot

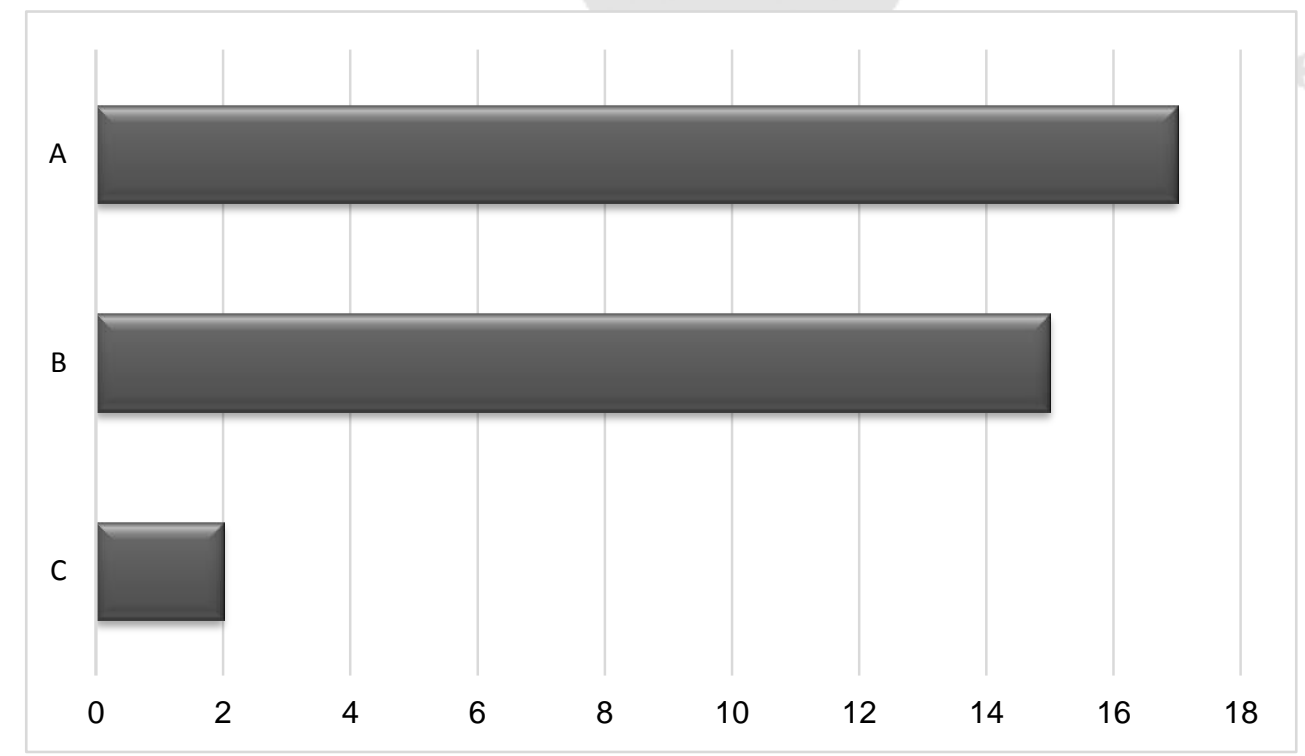

Nota: Número de participantes (20)

Fuente: Elaboración propia 
El 85\% de las participantes asigno el spot un nivel socioeconómico A, mientras que un $75 \%$ al B. (Gráfico 3.2.4.2)

\section{Gráfico 3.2.4.3}

Qué precio le asignaría en soles al producto

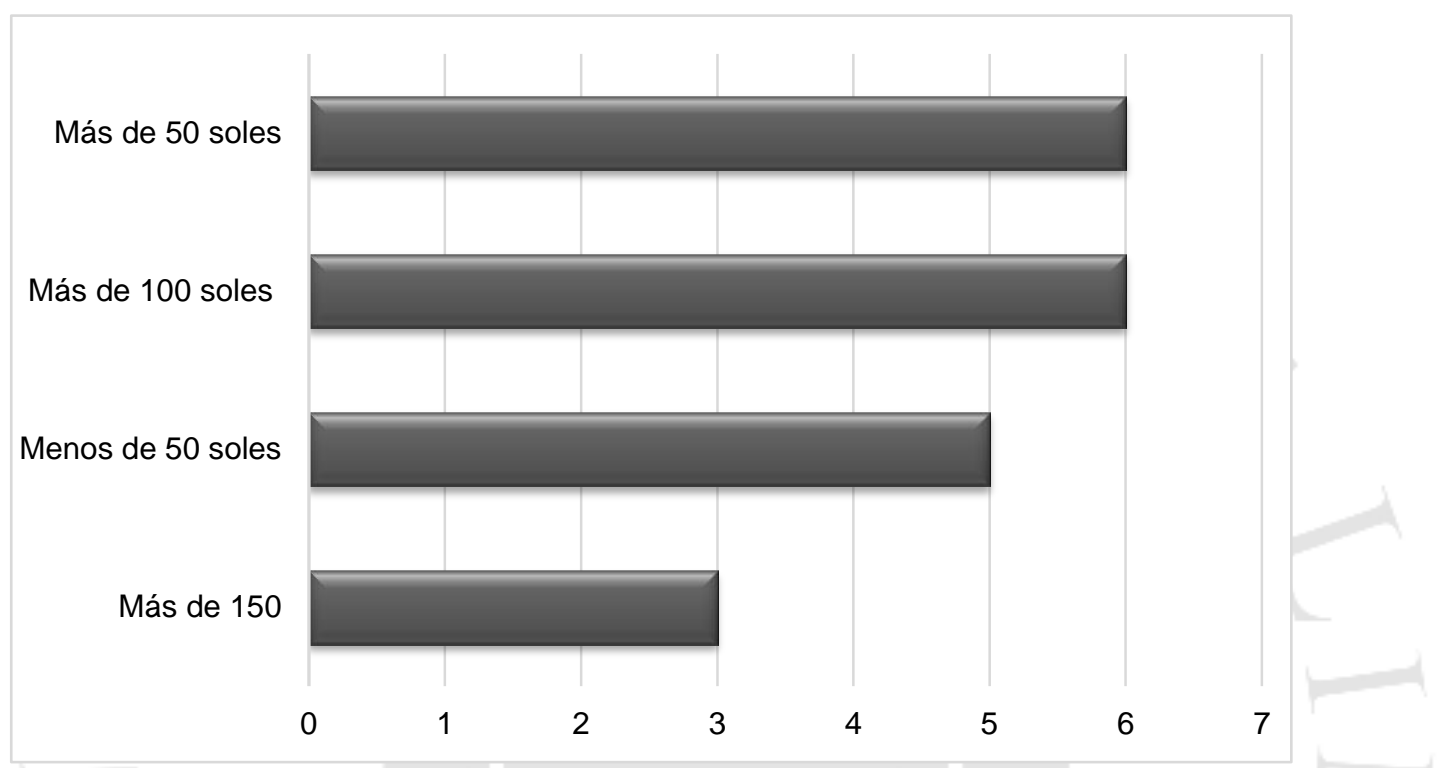

Nota: Número de participantes (20)

Fuente: Elaboración propia

El 30\% de las participantes asignaron un rango de precio de 50 a 100 soles al producto y a su vez un $30 \%$ uno de 100 a 150 soles. (Gráfico 3.2.4.3) 
Gráfico 3.2.4.4

Edad con que relaciona el spot

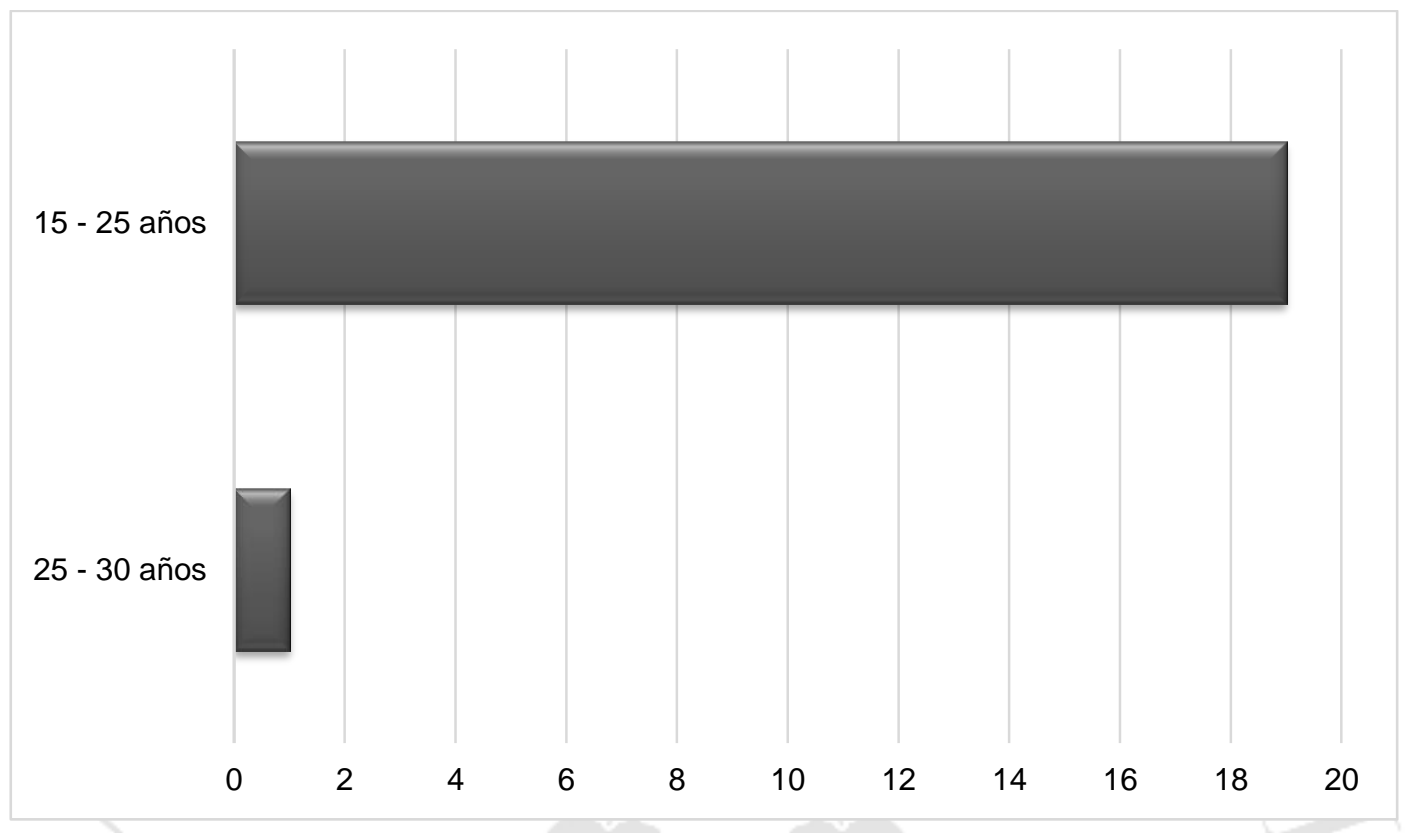

Nota: Número de participantes (20)

Fuente: Elaboración propia

El 95\% de las participantes relacionaron el spot con un rango de edad de 15 a 25

años. (Gráfico 3.2.4.4) 
Gráfico 3.2.4.5

Estilo de vida reflejado en el spot

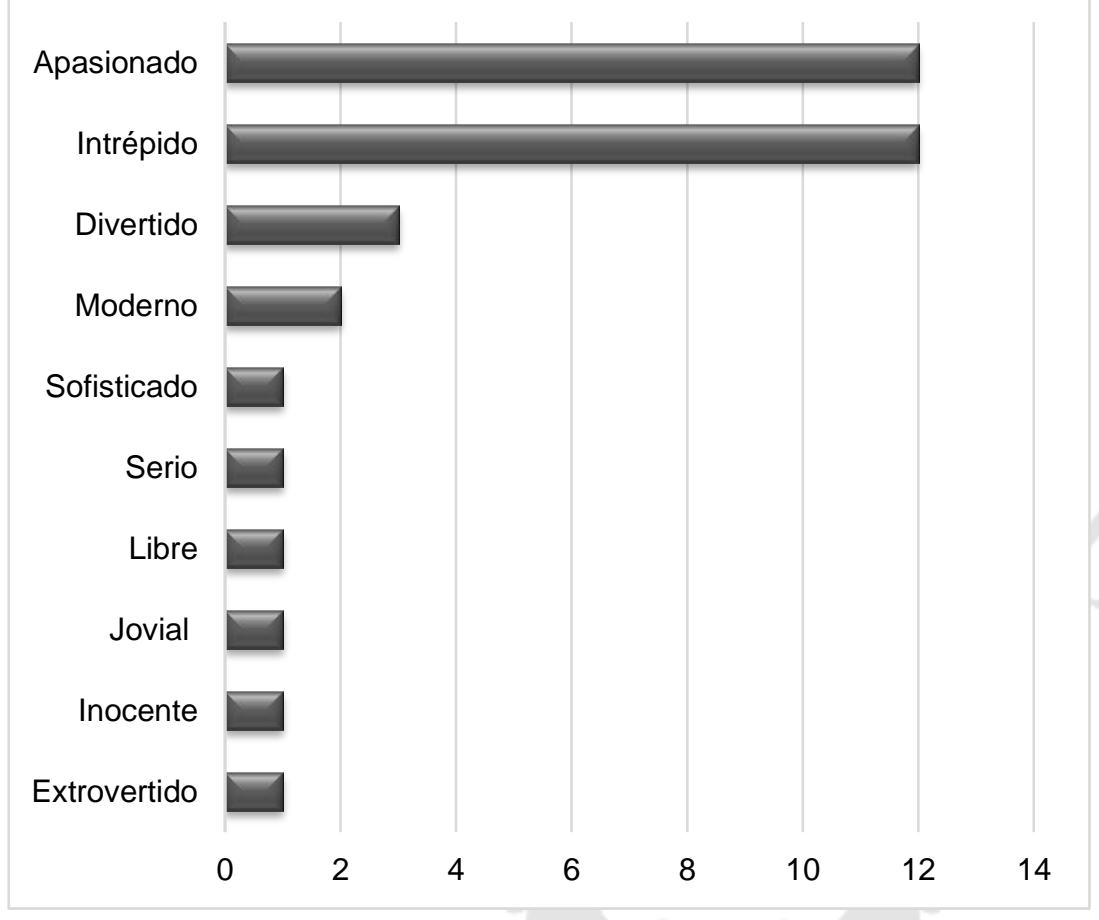

Nota: Número de participantes (20)

Fuente: Elaboración propia

Un $60 \%$ de las participantes relacionaron un estilo de vida apasionado y su vez intrépido al spot. (Gráfico 3.2.4.5)

En el spot Cacharel B, la pregunta “¿Qué le transmite el mensaje?” encontró los siguientes comentarios:

- "Un perfume de olor fuerte y floral".

- "Que la pasión se encuentra en el perfume".

- "Este perfume representa el olor de la pasión".

- "El producto te da más seguridad contigo misma".

- "Dejarte llevar por tus emociones".

- "El producto está relacionado con el concepto de amor intenso".

- "Una chica aventurera en busca del amor".

- “Gracias al perfume puedes encontrar el amor".

- "Que debe arriesgarse por lo que más ama".

- "Arriesgarse, atreverse".

- "Amar".

- "La esencia del perfume se asemeja a la del amor". 
- "Perfume que acompaña el amor".

- "El perfume da luz, ayuda a encontrar el camino".

- "El producto es intenso como el amor. Es pasional, lo necesitas en tu vida".

- "Que el amor está en todas partes y la pasión viene con el producto".

- "Que el perfume activa la pasión que los lleva a lugares antes no conocidos".

- "Enamórate y vive una pasión con el perfume".

- "El perfume del amor seductor".

\subsection{Resultados de entrevistas a expertos}

De manera complementaria se pueden revisar las entrevistas completas a expertos en la parte de anexos. Estas respuestas no son expresadas en gráficos, puesto que las preguntas son abiertas. 


\section{CONCLUSIONES}

\subsection{Análisis musical}

Las diferencias entre los spots modificados por nosotros y sus originales se pueden ver en las tablas 4.1.1 (para "Humor!" de Natura) y 4.1.2 (para “Amor amor" de Cacharel).

Tabla 4.1.1

Análisis musical del spot "Humor!” de Natura

\begin{tabular}{|c|c|c|}
\hline & Natura B (original) & Natura A (modificado) \\
\hline Melodía & $\begin{array}{c}\text { Tonalidad menor, escala pentatónica } \\
\text { menor }\end{array}$ & Tonalidad mayor (melodía indefinida) \\
\hline Armonía & $\begin{array}{l}\text { Parte I: do mayor } \\
\text { Parte II: do menor }\end{array}$ & Mi mayor \\
\hline Movimiento & $\begin{array}{l}\text { Parte I: ad libitum, sin pulso } \\
\text { Parte II: moderato }(116 \text { bmp*) }\end{array}$ & Allegro (120 bpm) \\
\hline Compás & $\begin{array}{c}\text { Parte I: } 3 / 4 \\
\text { Parte II: } 4 / 4\end{array}$ & $4 / 4$ \\
\hline Textura & $\begin{array}{l}\text { Parte I: synth pad, piano, cuerdas de } \\
\text { sintetizador } \\
\text { Parte II: voz, guitarra eléctrica, synth } \\
\text { pad, bajo, batería }\end{array}$ & $\begin{array}{c}\text { Guitarras (eléctrica, mute, acústica), } \\
\text { synth pad, piano, batería electrónica, } \\
\text { bajo }\end{array}$ \\
\hline Estilo & $\begin{array}{c}\text { Parte I: Ambiental } \\
\text { Parte II: pop alternativo }\end{array}$ & Pop \\
\hline Afinación & Estándar (mi) & Estándar (mi) \\
\hline * bpm: beats & por minuto. & \\
\hline
\end{tabular}

Nota: Número de participantes (20)

Fuente: Elaboración propia

Tabla 4.1.2

Análisis musical del spot "Amor amor" de Cacharel

\begin{tabular}{|l|c|c|}
\hline & Cacharel B (original) & Cacharel A (modificado) \\
\hline Melodía & Tonalidad de la menor & No hay \\
\hline Armonía & Basada en la menor & Re menor \\
\hline Movimiento & Adagio $(72$ bpm) & $4 / 4$ \\
\hline Compás & $4 / 4$ & Allegro (146 bpm) \\
\hline Textura & $\begin{array}{c}\text { Voz, piano, bajo, batería, } \\
\text { synth pad (cuerdas y vocal) }\end{array}$ & $\begin{array}{c}\text { Guitarra acústica, synth pad, bajo, } \\
\text { batería, cuerdas de sintetizador } \\
\text { (violín) }\end{array}$ \\
\hline Estilo & Balada rock (pop) & Pop \\
\hline Afinación & Estándar (mi) & Estándar (mi) \\
\hline
\end{tabular}

Nota: Número de participantes (20)

Fuente: Elaboración propia 


\subsection{Análisis de las entrevistas}

El análisis e interpretación de los resultados de las entrevistas a profundidad nos permite contrastar lo que las entrevistadas evocan luego de observar los spots, primero con la pista de música modificada (versiones "A") y luego con su audio original (versiones "B"), en cada caso. Las diferencias en estos resultados nos hablan acerca del papel de la música en la publicidad audiovisual.

\subsection{1 "Humor!" de Natura}

Como puede verse en la tabla 4.2.1 los resultados más resaltantes están relacionados con las emociones, las cuales se transforman de alegría en el spot Natura A (modificado) a tranquilidad en el B. En cuanto al nivel socioeconómico, al spot A está relacionado en primera instancia con el nivel $\mathrm{B}$, mientras que en segundo plano con el A, por otro lado en el spot B el nivel socioeconómico A y B cobran igual importancia. El precio en su totalidad fue asignado igual en los dos casos, es decir de 50 a 100 nuevos soles en su mayoría. En lo que respecta a la edad, la vincularon en ambos casos principalmente con el rango de 15 a 25 años; no obstante, en Natura A hay un mayor número de participantes que dieron a conocer esta opción. De acuerdo al perfil hay una ligera variación puesto que en Natura A encontramos características relacionadas a una mujer de perfil aventurero, mientras que al B se le añade a todos los anteriores el de tranquilo, así como divertido. Finalmente el mensaje principal en ambos casos tiene que ver con un estilo de vida y de ser.

Tabla 4.2.1

Codificación de respuestas a las entrevistas, spot "Humor!" de Natura

\begin{tabular}{|l|c|c|c|c|}
\hline & \multicolumn{3}{|c|}{ Spots } \\
\hline & Natura A (modificado) & $\%$ & Natura B (original) & $\%$ \\
\hline Emociones & Alegría & 75 & Tranquilidad & 55 \\
\hline Nivel & A & 55 & A & 75 \\
socioeconómico & B & 95 & B & 75 \\
\hline Precio & $50-100$ soles & 55 & $50-100$ soles & 65 \\
\hline Edad & $15-25$ años & 85 & $15-25$ años & 70 \\
\hline Perfil & Aventurero & 60 & Aventurero & 35 \\
& & & Tranquilo & 35 \\
& & & Divertido & 30 \\
\hline Mensaje & Estilo de vida y de ser & 75 & Estilo de vida y de ser & 60 \\
\hline
\end{tabular}

Nota: Número de participantes (20)

Fuente: Elaboración propia 


\subsection{2 "Amor amor" de Cacharel}

En el caso del spot de Cacharel, la tabla 4.2.2 presenta los resultados más sobresalientes. Entre ellos cabe destacar que la emoción del amor sigue siendo preponderante en ambos spots. El nivel socioeconómico se entiende como dirigido a dos niveles, A y B en su mayoría. Por otro lado, el precio en el spot A (modificado) es de 50 a 100 nuevos soles, el cual tiende a tener un rango menor al B (original), que abarca un mayor rango de precios que oscila entre 50 a 100 nuevos soles y 100 a 150 nuevos soles. De acuerdo al sexo, en su gran mayoría está relacionado a lo femenino en ambos casos. La edad (15-25 años) se mantiene en los dos casos; sin embargo, hay un mayor número de participantes que reafirman la edad en Cacharel B (original). El perfil evoluciona de manera visible, puesto que en Cacharel A (modificado) se relaciona con una mujer de perfil aventurero, mientras que en el $\mathrm{B}$, se relaciona principalmente con una de carácter intrépido y apasionado. En general, de acuerdo al mensaje principal, las participantes manifestaron para ambos spots el hecho de que les remiten a un estilo de vida y de ser más ligado a un concepto en su totalidad.

Tabla 4.2.2

Codificación de respuestas a las entrevistas, spot "Amor amor" de Cacharel

\begin{tabular}{|l|c|c|c|c|}
\hline & \multicolumn{4}{|c|}{ Spots } \\
\hline Emociones & Cacharel A (modificado) & $\%$ & Cacharel B (original) & $\%$ \\
& Amor & 80 & Amor & 55 \\
Nivel & & & Pasión & 50 \\
socioeconómico & A & 80 & A & 85 \\
Precio & 50 a 100 soles & 70 & 50 a 100 soles & 75 \\
\hline Edad & $15-25$ años & 65 & 100 a 150 soles & 30 \\
\hline Perfil & Aventurero & 70 & $15-25$ años & 95 \\
& Apasionado & 55 & Apasionado & 60 \\
\hline Mensaje & Estilo de vida y de ser & 85 & Estilo de vida y de ser & 90 \\
\hline
\end{tabular}

Nota: Número de participantes (20)

Fuente: Elaboración propia 


\subsection{Análisis técnico}

\subsection{1 "Humor!" de Natura B (spot original)}

Esta pista de estilo pop fue creada específicamente para uso del spot. Consta de dos partes: la primera (con una duración de 9 segundos) se caracteriza por tener una introducción ambiental en Do mayor, sin percusión, lo que da un carácter de armonía con el medio ambiente (naturaleza), evocando al mismo tiempo suspenso al momento en que una protagonista hace un obsequio a otra. Asimismo, se aprecia una armonía aguda simulando cuerdas frotadas que anuncia el descubrimiento del perfume dentro de la caja. Esta armonía, sostenida durante los segundos 8 a 15 como transición, busca conectar con la segunda parte, en la que se empieza a dar a conocer el concepto del perfume con la imagen fundida en sus siluetas. La armonía cambia a modo menor e incluye una voz de tipo "tribal" que se reconoce por estar en escala pentatónica menor, con variaciones tónicas de voz humana (melismas) que cobran protagonismo. Este elemento "tribal" remite a la vida en armonía con la naturaleza. En esta fase el ritmo ya es más marcado y se percibe la melodía de una guitarra con efectos de reverberación y repetición o eco (delay), que le otorgan frescura (acompañan imágenes de playa en tomas abiertas y elementos referentes al surf). Es relevante el cambio a partir del segundo 15 hasta el 23, puesto que la percusión básica se aligera, generando una relajación que acompaña tomas de descanso. Después de ello la melodía sigue su curso y aparecen en el video más elementos relacionados con la música (una protagonista tocando una guitarra; otra, una batería) y la playa (aire, atardecer, mar), cerrando la idea con la aparición del perfume en un fundido musical.

\subsection{2 "Humor!" de Natura A (spot modificado)}

La pista que hemos seleccionado para modificar el audio del spot original tiene la finalidad exclusivamente de encontrar contrastes; no ha sido producida específicamente para el video. La parte introductoria (primeros 15 segundos) tiene una guitarra tocando ostinatos (repetición de las mismas notas), acompañada de percusión. En la segunda parte entra el piano y esboza una melodía indefinida. La pista está en escala mayor (Mi mayor), tónica que genera un aire de plenitud aunque el primer acorde sea menor (Do sostenido menor). Los instrumentos usados son neutrales y versátiles (guitarra, guitarra mute, guitarra acústica, synth pad, piano, bajo, batería electrónica). El estilo es rock pop y la pista carece de los elementos folclóricos o "tribales" del original. 


\subsection{3 "Amor amor" de Cacharel (spot original)}

Para este spot los publicistas de Cacharel han utilizado una canción ya existente: "Gravity", décima pista del álbum Reflection del grupo de origen belga Hooverphonic (2013), reconocido por su pertenencia a los géneros “europop” emanados de la escena synth-pop, trip-hop y dream-pop de los años noventa (aunque "Gravity" no alcanzó posiciones ventajosas en las estadísticas de popularidad, el álbum llegó a primer lugar en Bélgica y 51 en los Países Bajos). El fragmento de esta canción utilizado en la publicidad del perfume "Amor amor" tiene la siguente letra (en inglés el original; añadimos nuestra traducción en la columna derecha):

Gravity controls, gravity controls

The way we are falling

Gravity controls, gravity controls

The way we sink

We're floating into space,

floating into space

So boy, why don't you kiss me?
La gravedad controla, la gravedad controla la forma en que caemos

La gravedad controla, la gravedad controla la forma en que nos hundimos

Estamos flotando hacia el espacio, flotando hacia el espacio

Así que, chico, ¿por qué no me besas?

Se trata de una balada rock en inglés, lo que también apela al nivel cognitivo del público pues hay cierto goce en entender la letra más allá de la intención al cantarla; da un sentido de sofisticación. La canción tiene una introducción con piano (de 16 segundos aproximadamente) en la tonalidad de La menor; el tiempo es lento y algo melancólico. El spot muestra imágenes en blanco y negro: una pareja de jóvenes solos, aparentemente perdidos, cerca de una cueva. En la siguiente fase se puede oír un crescendo que desemboca en el coro de la canción; aquí se aprecia a la joven llevando a su acompañante dentro de la cueva y con la otra mano sosteniendo el perfume. Mientras prosigue el coro, ellos corren hacia un final indefinido, aparentemente dan un salto al vacío, donde se da una especie de simulación de enamoramiento. La pareja flota en el vacío, momento que se acompaña con voces, dando una sensación más ambiental. En la última fase, cuando la pareja parece volver a la cueva y se besa (del segundo 38 hacia el final) llegamos al clímax de la canción con un diminuendo súbito de la instrumentación. 


\subsection{4 "Amor amor" de Cacharel (spot modificado)}

Esta pista también ha sido seleccionada con el fin de encontrar contrastes en nuestra investigación. Está en la tonalidad de Re menor; no obstante, el ritmo es rápido y no se siente melancólico. La melodía es indefinida y es notable una guitarra arpegiando, reforzada por un violín, ambos haciendo ostinatos. El estilo es pop. Tanto en este caso como en el de "Humor!" de Natura, las pistas seleccionadas para la modificación del audio, al ser clips de corta duración (Jamendo Music, s. f.), han sido reproducidos mediante bucles (loops), lo que significa que se repiten y no se definen; se podría decir que son "moldeables" y no tan definidos o intensos como los audios originales.

\subsection{Conclusión final}

Deben tenerse en consideración diversos elementos para que la música pueda ser dirigida hacia una significación específica. A diferencia de lo que sucede con la música religiosa y algunas formas folclóricas relacionadas con rituales concretos, que son de sentido unívoco (la audiencia entiende un sentido específico), la música en general se caracteriza por ser polisémica, es decir, por su capacidad de evocar sentidos diferentes en cada oyente y en cada contexto. De acuerdo con las respuestas de las participantes en nuestro estudio ante los videos que se les han mostrado, hay variaciones relevantes que explicaremos a continuación.

Por los resultados más sobresalientes de las entrevistas a participantes es posible concluir, en primera instancia, que el valor añadido de la música tiene un efecto en el plano emocional y de sensaciones en este experimento.

En el caso del spot "Humor!" de Natura B (original), su música está basada en tonalidad de do mayor en su introducción y en do menor en lo que resta de la pista; según las respuestas de las entrevistadas hay mayor tendencia a la sensaciones de tranquilidad y en torno al estilo de vida nombran diversos atributos como: El tranquilo, el aventurero y el divertido. Respecto a la tranquilidad, encontramos un primer argumento emocional por el uso del pad, ya que tiene un ataque duradero y la facultad de crear atmosferas. La voz es pieza clave, ya que al ser tribal da la sensación de volver a lo natural, a lo universal, a la igualdad, a lo visceral, remite al vínculo humano en una pista instrumental y ofrece un perfil aventurero más detallado por las imágenes al estar más ligado a una situación (playa, bosque, carreteras). El juego con la percusión posee un lenguaje audiovisual, puesto que en el primer descanso se revela la identidad del 
perfume aportando misterio y luego; en el segundo, hay un énfasis en mostrar a las protagonistas en posición de descanso (echadas), lo cual reafirma a su vez el valor de la tranquilidad gráficamente al ser esta posición símbolo de susceptibilidad y sumisión. Así mismo las escenas de diversión se acentúan con el inicio de la percusión (sin pulso a 116 bpm), la cual anuncia movimiento a través de acciones como surfear y viajar.

En el caso del spot de "Humor!" de Natura A (modificado) encontramos una tonalidad mayor que refuerza la sensación de alegría a través de los ostinatos y su tempo (allegro), más rápido que el original. También se relaciona con lo aventurero; sin embargo, según las participantes no hay tanta presencia de tranquilidad específicamente, lo cual podría deberse a la ausencia de voz humana, de la que esta pista carece, tampoco hay énfasis en la diversión.

En el caso de la versión original del spot "Amor amor" de Cacharel B (original, con música de Hooverphonic) las participantes manifiestan un sentimiento de amor principalmente y de pasión en segundo plano, con inclinación a lo intrépido (arriesgado) y lo pasional. En cambio, en el spot modificado (Cacharel A, con pista de banco de sonidos), el amor es el sentimiento principal y es de orden pasional, pero aventurero, es decir menos intenso que el anterior. Ambas pistas están en tonalidad menor; sin embargo, en el original se explotan más las texturas; el piano grave, los coros de fondo y la voz humana femenina generan mayor peso y tensión, y llevan a un clímax, mientras que el spot modificado, que es lineal y solo instrumental, ha sido relacionado más con un hecho fugaz, una aventura. La idea en ambos sigue siendo firmemente "amor" identificados por los actos de los actores. Aquí se podría decir que se desarrolla un fenómeno con respecto al aumento del precio de una pista a otra, ya que en el spot original una parte considerable de participantes manifiesta un rango de precio mayor, de 100 a 150 soles, es decir que la música también conlleva elementos que sugieren mayor costo o nivel socioeconómico, lo cual está relacionado al idioma, la voz de la cantante y los instrumentos.

Finalmente, a partir de esta investigación se deduce que la música contribuye en más de un $50 \%$ a que en las historias relatadas por los spots seleccionados las emociones varíen como en el caso de Natura con "la alegría" vs "la tranquilidad" o sean tipificadas como en el caso de Cacharel con el sentimiento del "amor pasional intrépido vs el amor pasional aventurero" y a su vez con consecuencias respecto al precio, el cual sube notablemente con el spot original del rango de 50 a 100 soles a 100 a 150 soles en el 
segundo caso. Los resultados son visibles inclusive sabiendo que el ser humano es altamente visual y virtual; en este caso en mayor medida mujeres adolescentes por su edad y sensibilidad (argumento sustentado en la parte introductoria). Al igual que la imagen, la música también lleva cargas simbólicas tácitas en forma de melodías, armonías y ritmos con las que se estructuran en mayor medida, en los casos señalados, emociones y estilos de vida, factores importantes para la publicidad.

En este experimento los efectos del valor añadido de la música en spots publicitarios para perfumes para adolescentes en Lima se reflejan a nivel diferencial en las sensaciones (los dos casos), el estilo de vida (los dos casos) y el precio asignado (caso Cacharel). La música genera más que un marco para las acciones vistas, brindándoles una determinada intención, clasificación y la capacidad de desviar el mensaje principal del enunciante si es que es alterada.

Repercute e interviene en la asignación de emociones nuevas, en el valor económico del producto y en la clasificación de una determinada emoción, otorgándole diferentes características a los perfiles, es decir generando más exactitud respecto al mensaje que se quiere comunicar. He ahí el valor agregado. 


\section{RECOMENDACIONES}

Es clara la necesidad de desarrollar más investigación sobre el papel de la música y su impacto a nivel audiovisual, así y como su rol cognitivo en todo tipo de campos, especialmente el publicitario, dado que puede afectar de diferentes maneras la recepción de mensajes, y que las categorías cobran valores distintos, tanto a nivel publicitario como televisivo, cinematográfico y de otros medios, lo que puede ayudar a hacer más eficiente la inversión en publicidad.

Según los expertos consultados, la música en publicidad tiende a estar condicionada en la mayoría de casos por el prepuesto que por recomendación de los productores musicales, aun cuando se sabe que es de vital importancia para el spot por su relevante papel en la definición del concepto. Los expertos del área que hemos consultado (anexo 3) afirman que lo más conveniente, en cualquier caso, es crear la música específicamente para un fin.

A partir de este estudio cabría profundizar, entonces, con investigaciones sobre el impacto de la música (y los géneros específicos) y su relación con diferentes precios, ya que esta no se puede graficar, no muestra raza o sexo, sin embargo, de acuerdo a los resultados en esta investigación, si existen factores que generan un cambio interesante de percepción hacia el precio de una pista a otra.

A su vez investigar a nivel cultural, cómo es que se procesa la música. Así como cuáles deben ser las formas y estilos más adecuados para cada finalidad publicitaria (nivel socioeconómico y tipo de productos o servicios promocionados) 


\section{REFERENCIAS}

Arens, W. (2000). Publicidad (7ª ed.). México: Edit. McGraw-Hill.

Ball, P. (2010). El instinto musical. Escuchar, pensar y vivir la música. Madrid: Turner.

Balsebre, A. (1994). El lenguaje radiofónico. Madrid: Cátedra.

Bassat, L. (1993). El libro Rojo de la publicidad (Ideas que mueven montañas). Barcelona: Folio.

Borrero-Morales, F. J. (diciembre de 2008). Los elementos de la música. Innovación y experiencias edicativas 13. Recuperado de https://archivos.csif.es/archivos/andalucia/ensenanza/revistas/ csicsif/revista/pdf/Numero_13/FCO_DANIEL_BORRERO_2.pdf

Brand sense: publicidad a través del imperio de los sentidos (2007). Marketing News 2 (10).

Cacharel (s. f.). Página en internet de la empresa Cacharel. Recuperado de: http://www.cacharel.fr (actualmente no disponible).

Chapman A. (2007). Maslow's Hierarchy of Needs. Recuperado de: www.businessballs.com/ maslow.htm

Chion, M. (1990). La audiovisión. Introducción a un análisis conjunto de la imagen y el sonido. Barcelona: Paidós.

Damasio, A. R. (1994). El error de Descartes: La emoción, la razón y el cerebro humano. Santiago de Chile: Andrés Bello.

Diario La República. (1 de octubre del 2015).La televisión es el medio de comunicación de mayor consumo en el Perú. Diario La República. Recuperado de https://larepublica.pe/economia/885655-la-television-el-medio-decomunicacion-de-mayor-consumo-en-el-peru

Dichter, E. (1969). Las motivaciones del consumidor. Buenos Aires: Editorial Sudamericana

G Castillejo. (29 de noviembre del 2011).Marketing dirigido a la mujer un inmenso mercado que presenta grandes desafíos. Marketing Directo. Recuperado de https://www.marketingdirecto.com/punto-de-vista/la-columna/marketingdirigido-a-la-mujer-un-inmenso-mercado-que-presenta-grandes-desafios-3

González Martín, J. A. (1996): Teoría general de la publicidad, Madrid: Fondo de Cultura Económica. 
González, M. y Carrero, E. (2008). Manual de planificación de medios (5ª ed.). España: edit. Esic

Hooverphonic (2013). Gravity. En Reflection [CD]. Bélgica: Sony Music Entertainment.

Jamendo Music (s. f.). Página en internet de la empresa Jamendo, catálogo musical. Recuperado de: https://www.jamendo.com

Martín, J. A. (1996). Teoría general de la publicidad. Madrid: Fondo de Cultura Económica.

Medina, M. C. (4 de septiembre de 2017). Seis de cada diez perfumes en el Perú se venden por catálogo. Diario Correo. Recuperado de https://diariocorreo.pe/economia/seis-de-cada-diez-perfumes-en-el-peru-sevenden-por-catalogo-771474/

Meu Primeiro Humor - Fragancia Femenina (s. f.). Página en internet de la empresa Natura. Recuperado de: http://www.natura.com.pe/nuestrasmarcas/naturahumor/meu-primeiro-humor-fragancia-femenina

Mujeres y compras: ¡Me lo llevo! (14 de octubre de 2012). Revista Mujer. Recuperado de: http://www.revistamujer. cl/2012/10/14/01/contenido/19_4002_9.shtml/

Pablo Bobadilla (2018). Desarrollo de partituras de spots publicitarios (Cacharel y Natura)

Pérez, H. (2007). Televisión. Caracas: Edit. Comala.com

Piñeiro-Otero, T. (junio-noviembre, 2015). Del jingle a las radios corporativas. Prisma Social, revista de ciencias sociales 14 (pp. 663-688). ISSN: 1989-3469.

Real Academia Española (2018). Diccionario de la lengua española. Recuperado de www.rae.es.

Reguan-Álvarez, M., y Torrado-Fonseca, M. (2016). El método Delphi. REIRE, Revista d'Innovació i Recerca en Educació 9 (1), pp. 87-102. DOI: 10.1344/reire2016.9.1916.

Sammy Danna, R. (1992). Publicidad y cultura popular. EEUU: Popular press

Rey, J. (1992). La significación publicitaria. Sevilla: Alfar.

Roman, K. y Maas, J. (1995). El nuevo cómo anunciar. Madrid: Edipo. S. a. (1978).

Universidad de Lima (2018). Bases de datos con investigaciones de IPSOS-Apoyo, 2007, 2010, 2015.

Vázquez, B. L. (2007). Publicidad emocional. España: ESIC editorial. 
Vera-Romero, O. E., y Vera-Romero, F. M. (2013). Evaluación del nivel socioeconómico: presentación de una escala adaptada en una población de Lambayeque. Rev. Cuerpo méd. HNAAAA 6 (1) (pp. 41-45). 


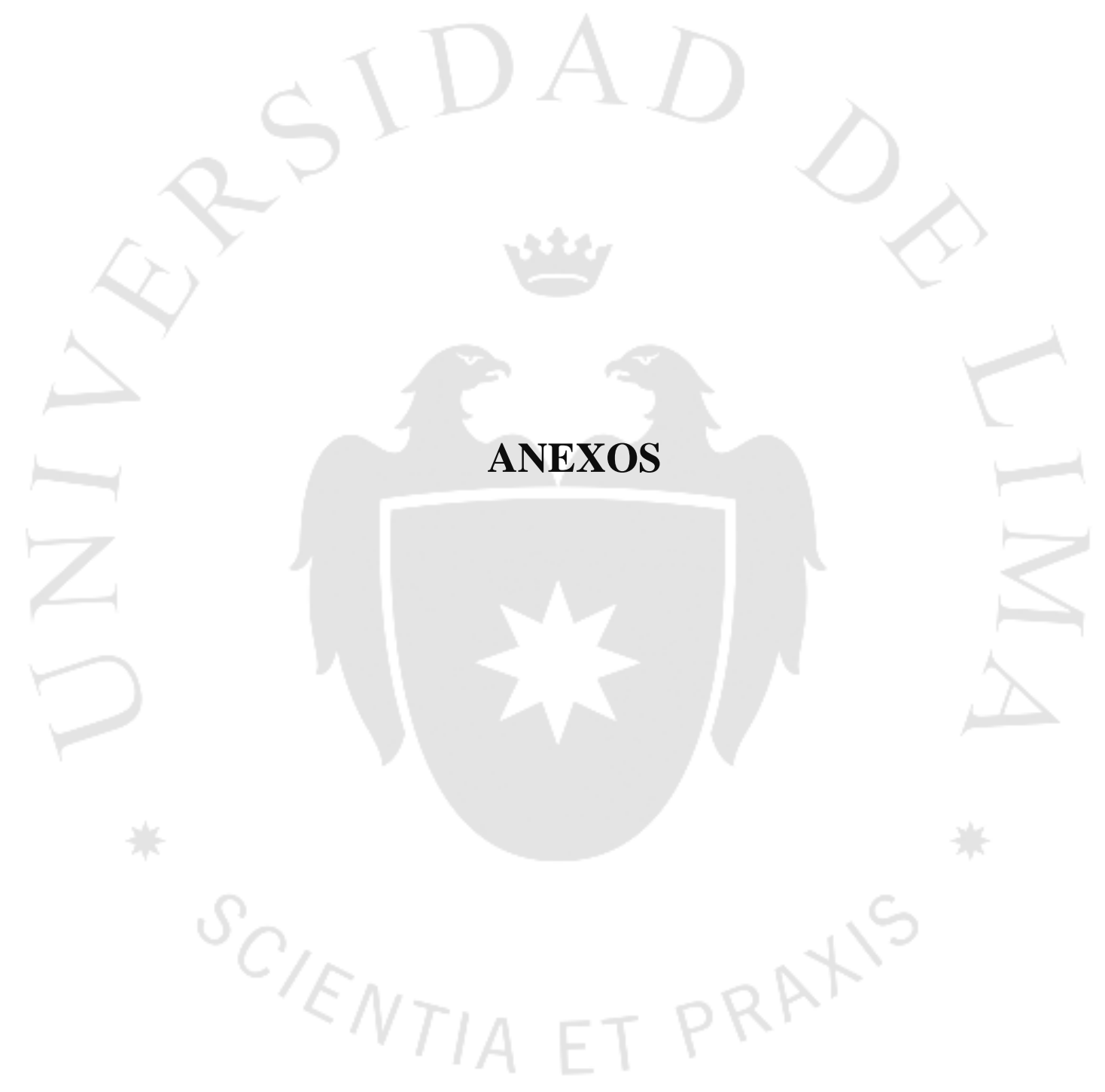




\section{ANEXO 1: Partituras de pistas originales}

Partitura pista Natura B (original)

Score

NATAL NATURE - PRESENTE HUMOR

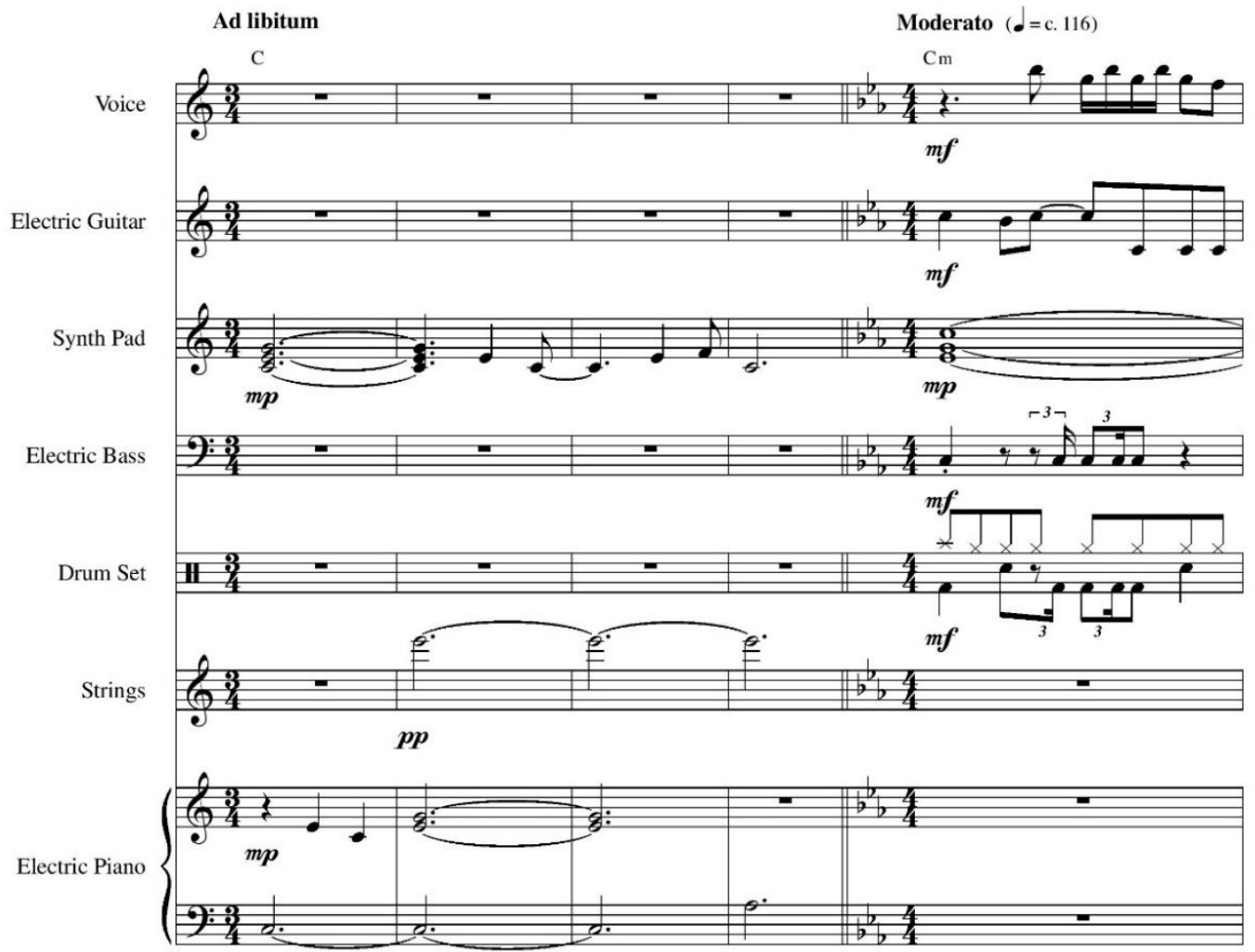




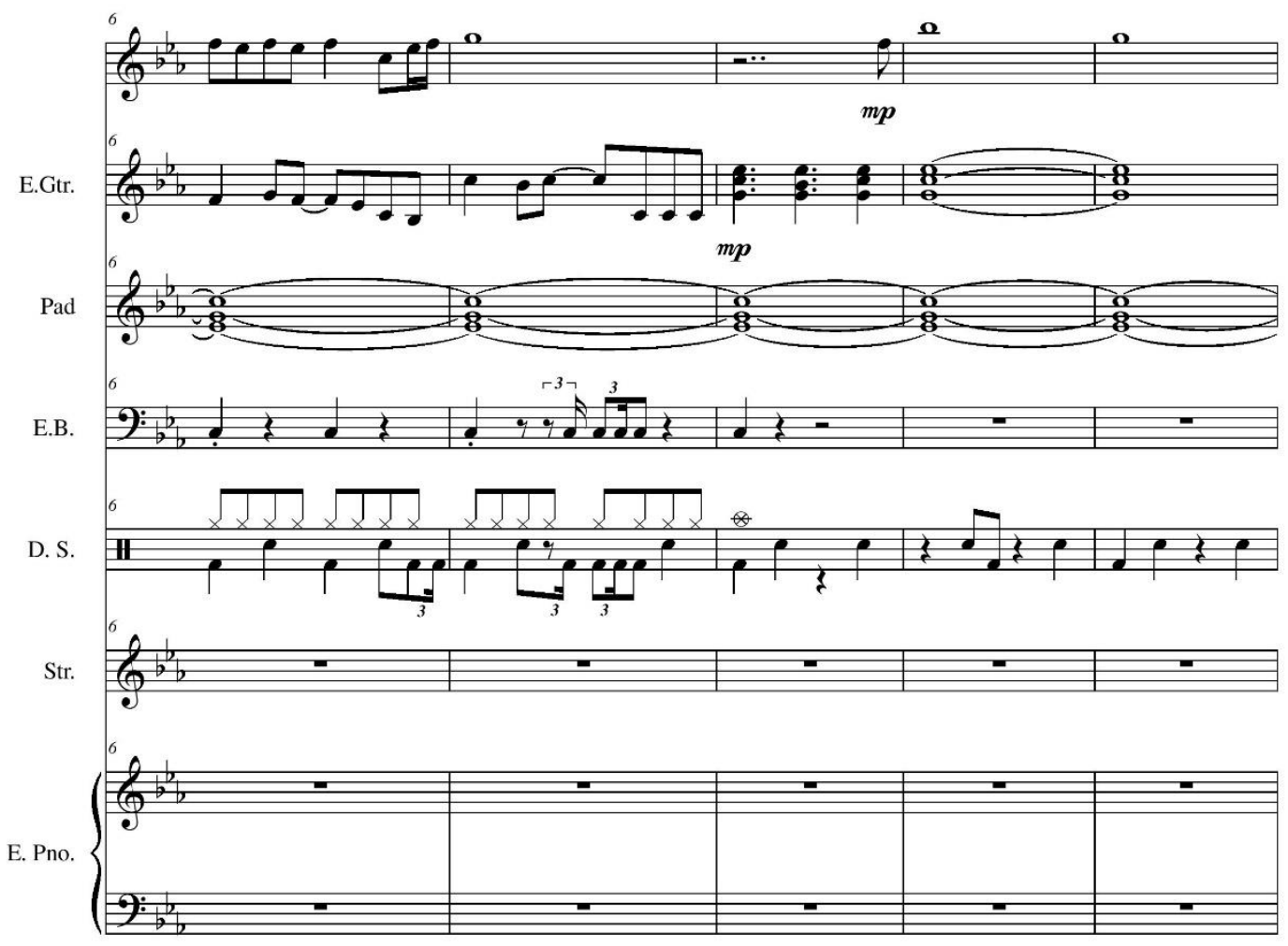




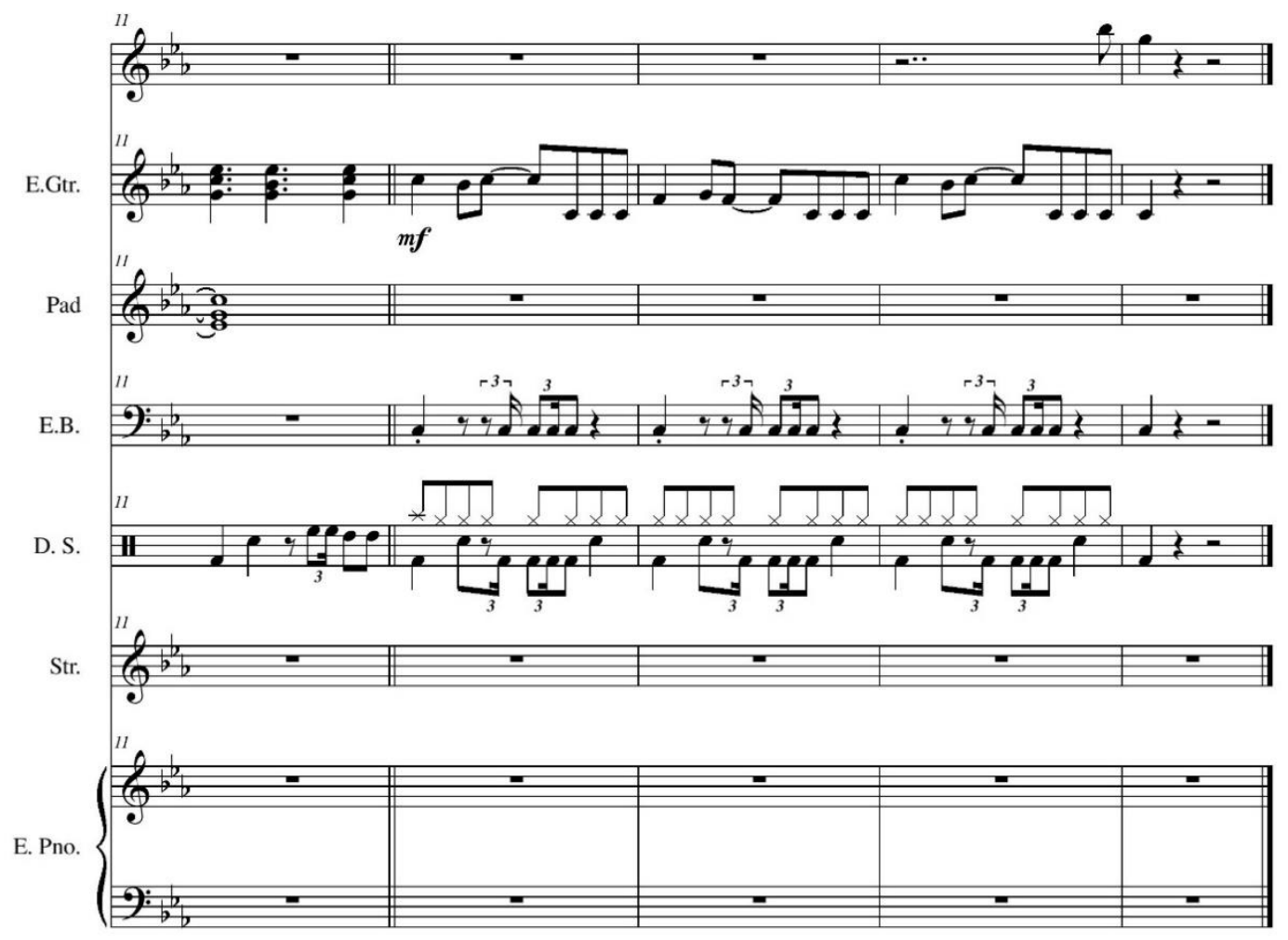


Partitura pista Cacharel B (original)

\section{Score ANUNCIO AMOR AMOR CACHAREL}

(REVEAL 2016)

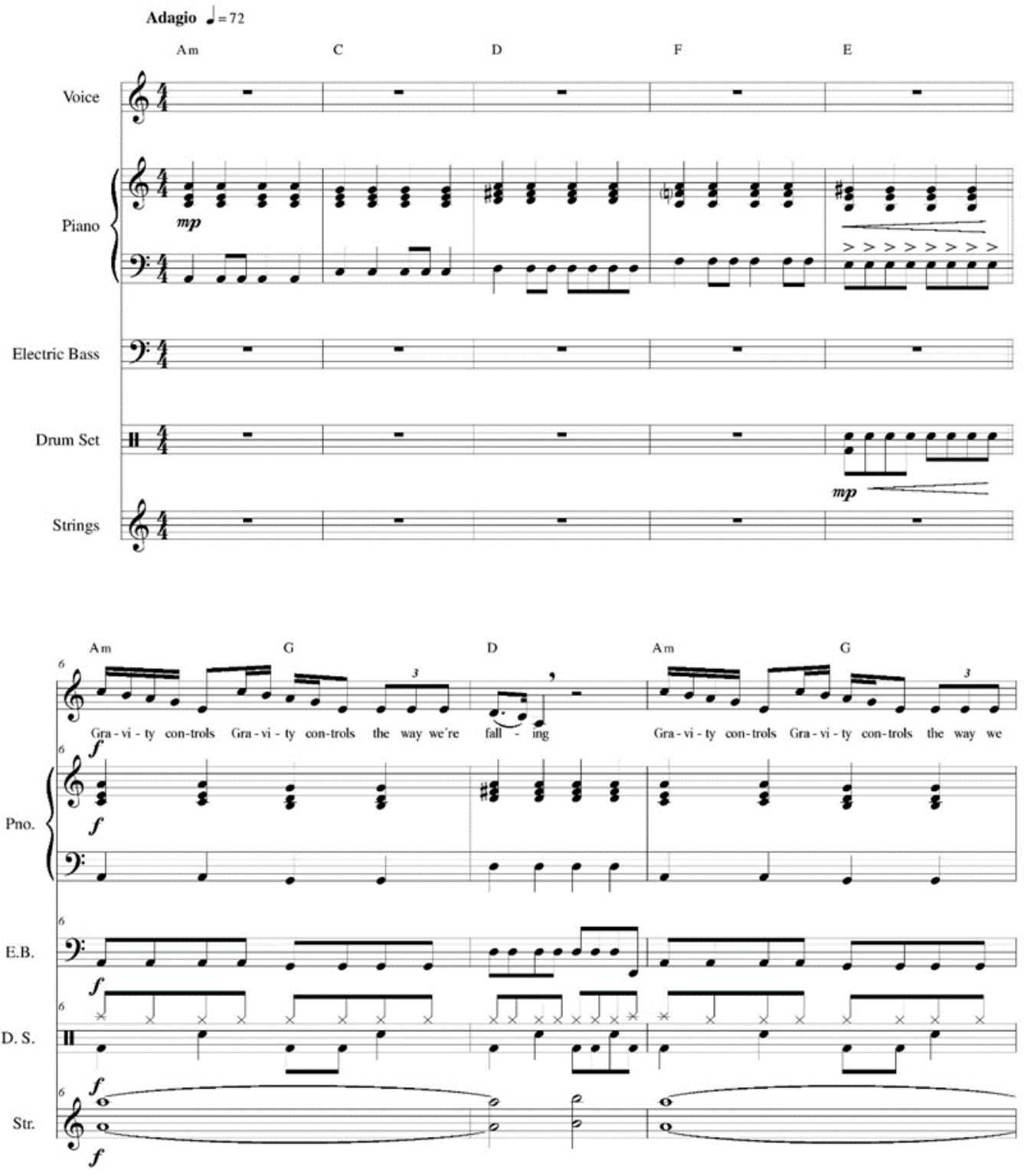

(OPBR2018 
ANUNCIO AMOR AMOR CACHAREL
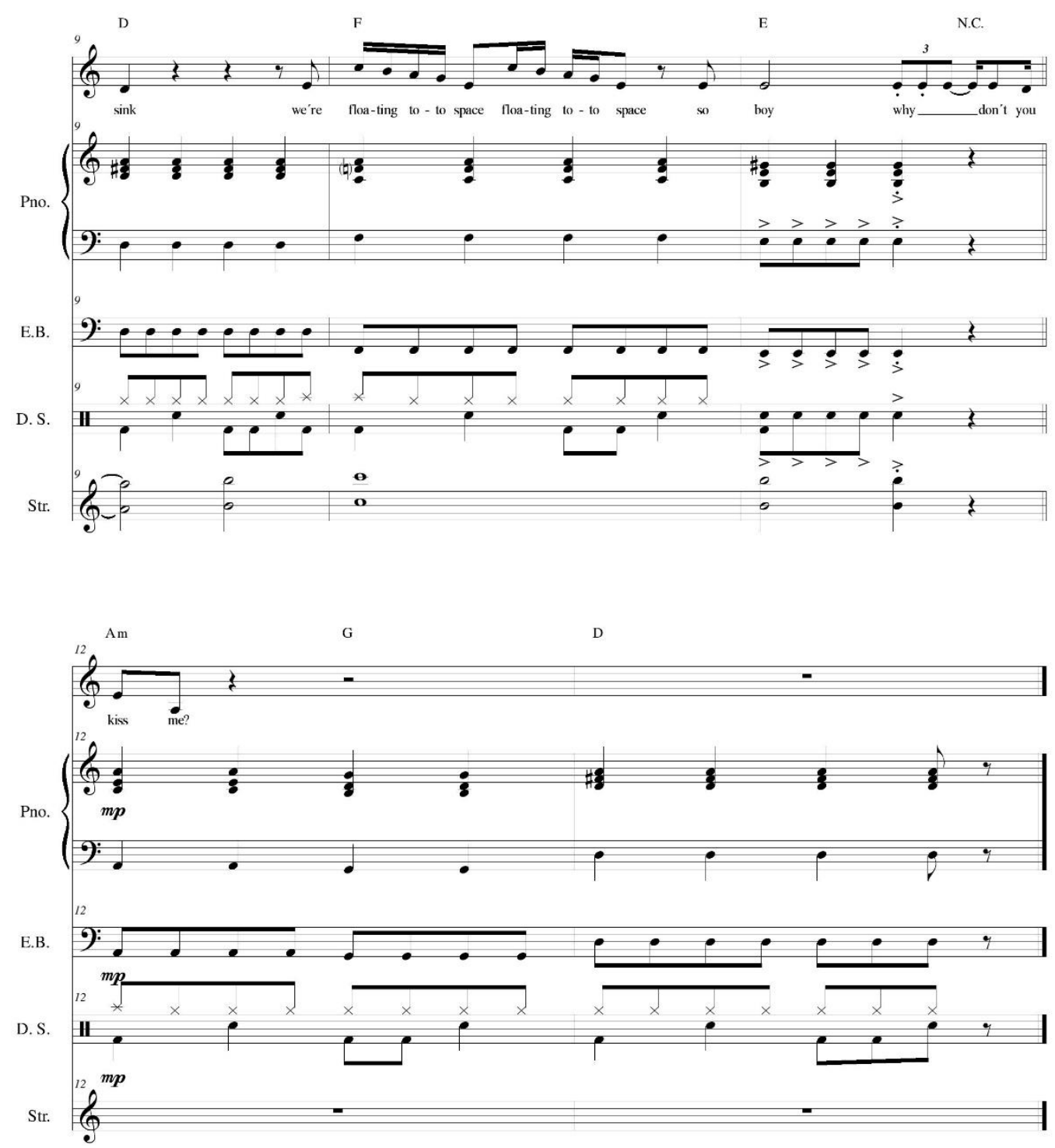


\section{ANEXO 2: Partituras de pistas modificadas}

Partitura pista Natura A (modificado)

Score

$$
\text { VIDEO SUGERIDO - ENTREVISTA }
$$

Allegro (M.M. $d=$ c. 120)

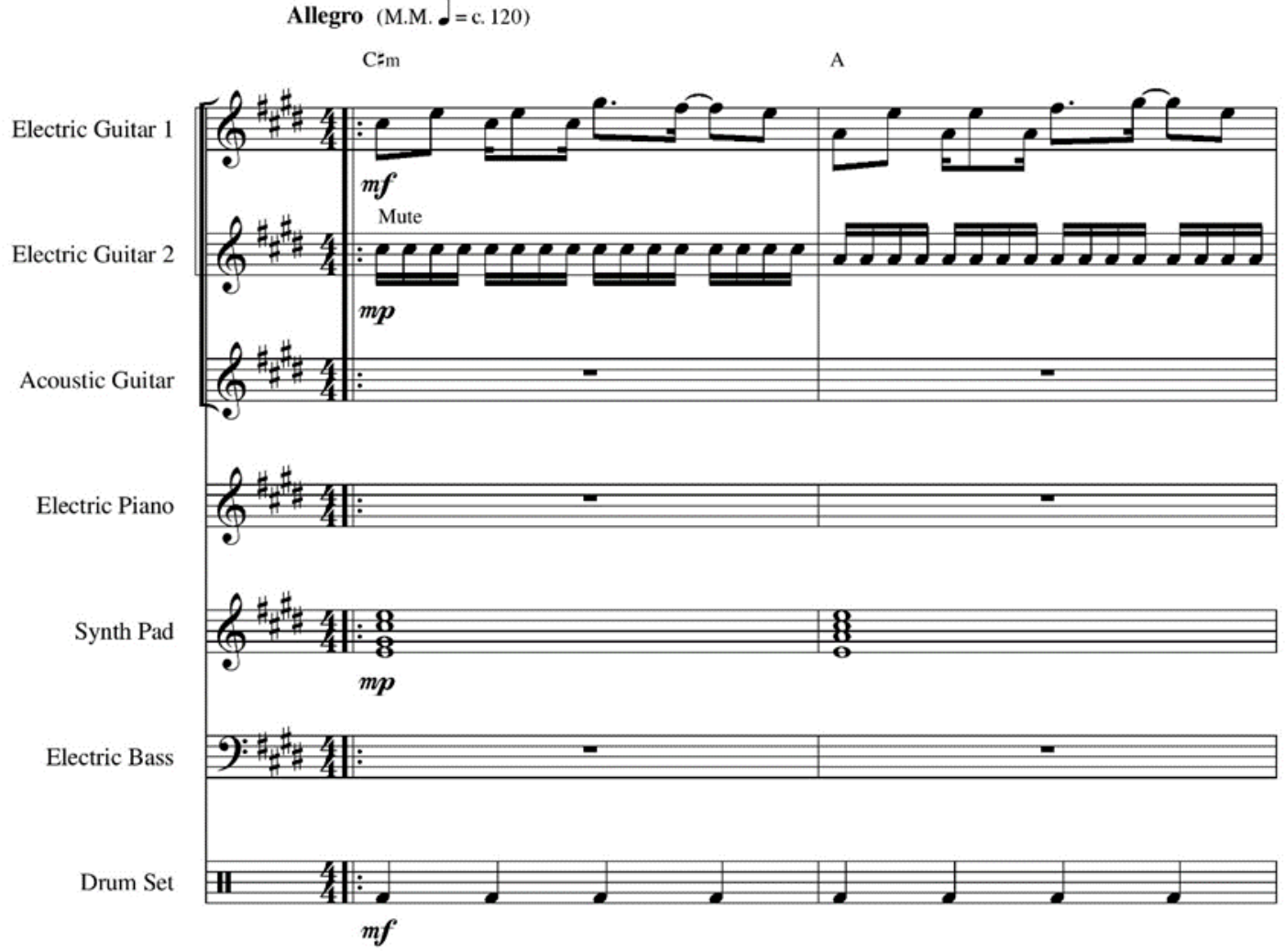

OPBR2018 


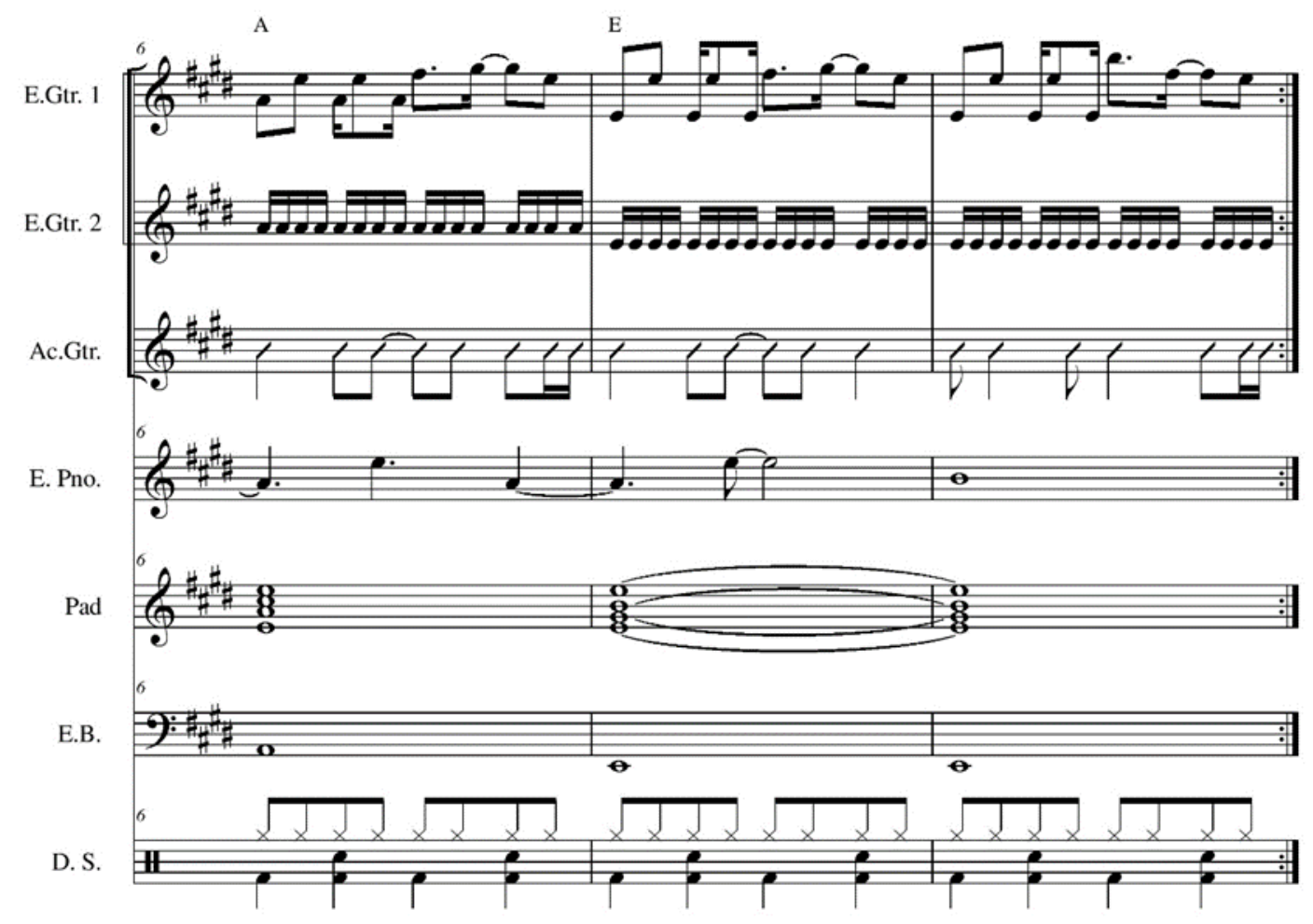


Partitura pista Cacharel A (modificado)

\section{Score VIDEO SUGERIDO 2 / ENTREVISTA}
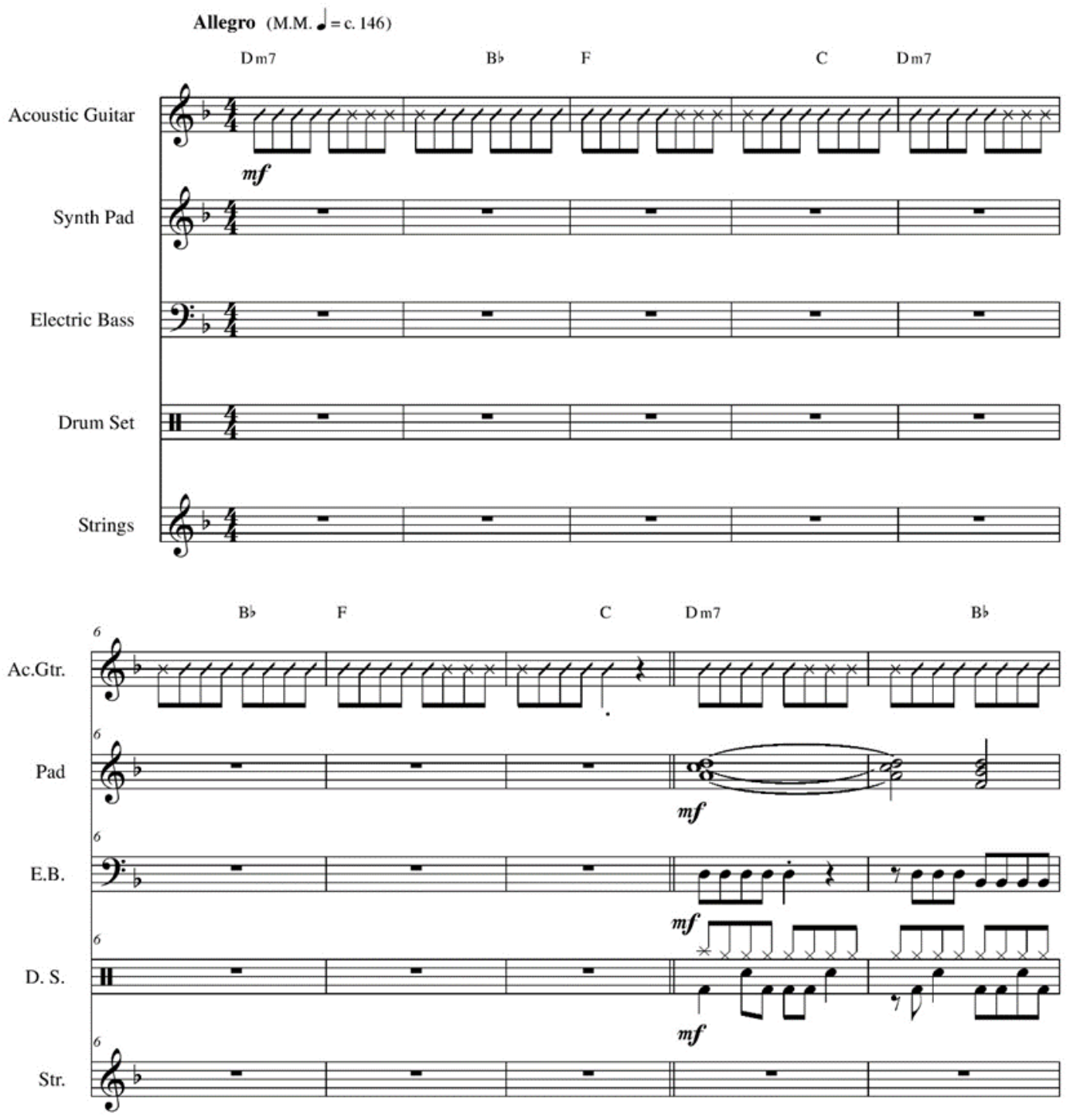

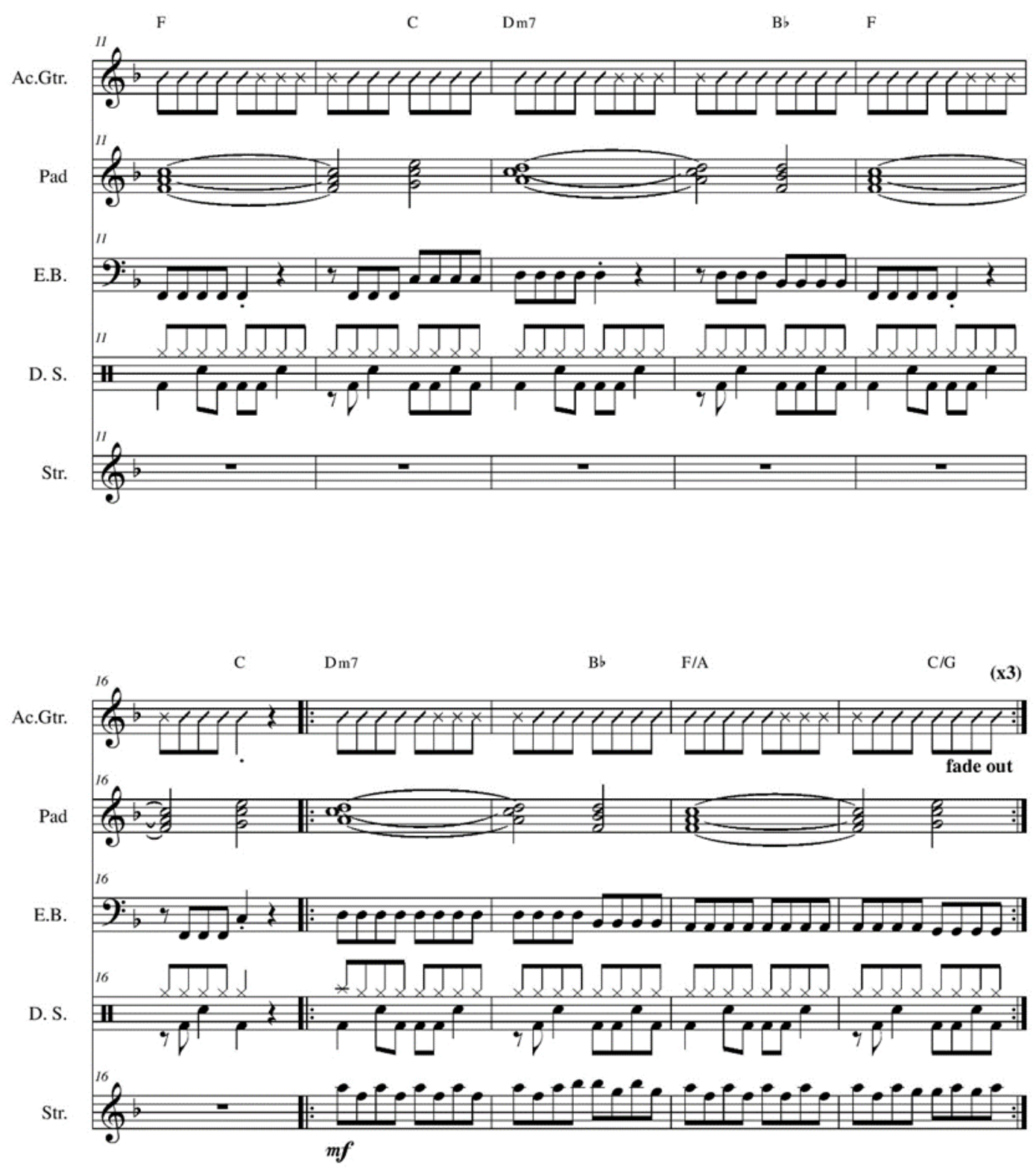


\section{ANEXO 3: Transcripción de entrevistas a expertos}

A continuación la transcripción de las entrevistas a expertos:

\section{Karin Zielinski - Productora musical en Stereomonkey (Casa de Diseño} sonoro)

1. ¿Cuáles son los factores fundamentales en la pre - producción musical para un spot publicitario?

-La pre producción se trabaja con la agencia, esta viene y te plantea los conceptos, cuáles son las sensaciones que se buscan en la campaña. Generalmente, en teoría, se hace la reunión de pre producción, y en ella se junta la agencia con la casa realizadora y la casa de audio, ahí se plantea cuál es el concepto de la campaña, qué se quiere vender, qué se quiere generar en cuanto a sensaciones y maso menos cuáles son las referencias que ellos tienen, tanto en vestuario, visuales y sonoras. Generalmente hablan de alguna película u otra campaña de comercial de fuera, en lo que se quieran basar para la realización, en base a eso se buscan las referencias específicas que vayan de acuerdo a lo que se haya dicho en la reunión, entonces se buscan tres, cuatro o cinco referencias y la agencia escoge cuál de ellas funciona más con lo que se quiere vender. Una vez que la agencia escoge la referencia, se empieza trabajar con ellas. Se trabaja con referencias, porque mientras más específico seas en la pre producción es mejor. En publicidad hay munchas cabezas que deciden, entonces nunca se llega a un acuerdo concreto, mientras tú como compositor plantees o tengas el panorama claro es mejor, así la agencia y el cliente estarán tranquilos con lo que se trabaje. Los Factores fundamentes son tener referencias y hablar con los creativos, quienes deciden los conceptos, los géneros y todo lo que se va a trabajar .

2. ¿En qué medida y cuánto afecta la música a un spot publicitario? ¿de qué depende el impacto?

‘La música afecta muchísimo, es el 50\% del spot, depende del spot, pero lo que sucede es que la música te mueve sensaciones, te plantea la atmósfera, 
te remarca cosas, te manipula un poco. Una campaña sobre una colecta nacional, por ejemplo, la teletón, te mueve el tema de sentimiento, para una gaseosa juvenil, podría usarse un pop o rock pop, también depende del público al que vas, si vas al a, b, c, qué géneros se mueven más. El impacto depende del mensaje, de qué tan efectivo está siendo con lo que el spot plantea, así la comunicación entre el creativo y tu va a ser mejor."

3. ¿Cómo se trabaja o trata un producto conceptual (ej: perfumes/olor) al momento de crear una pista para su spot? (cómo se concibe en la pre producción) ¿cómo lo desarrollarías?

En la pre producción se plantea el concepto de la campaña, depende de la situación, tú también puedes proponer. El músico propone cuando se proponen las referencias, ya que los creativos te sugieren y delimitan, y te piden buscar una referencia determinada. Por ejemplo, buscar una referencia como "Despacito", entonces yo busco una así y voy a tener que trabajar un primo hermano de la canción. A qué me refiero? a hacer una música que te genera la misma sensación de "Despacito", yo tengo que generar, no copiar, sino generar la sensación, por ejemplo, puedo coger su mismo Groove o puedo trabajar el mismo ritmo, si la canción original está en 125 bpm, entonces yo también trabajo así para generar ese ritmo, es ver qué cosa de la referencia puedes utilizar en tu propuesta.

4. Criterios para la elección de un género y estilo en un spot publicitario

“El estilo de un spot publicitario te lo plantea la agencia, a ti te llaman para hacer algo específico, la elección tú puedes proponerla, pero ellos antes te la delimitan, a veces el cliente no lo tiene claro, y puedes mejorar la propuesta del cliente. Entonces ya sabes qué sensaciones debes generar y, por ejemplo, si quieres energía, hay tres formas con tres géneros distintos, podría ser indie rock con palmas y guitarras, con upbeat, o un dubstep o algo tirado para lo electrónico. Acá la palabra clave es cuál es la sensación 
que quiero transmitir, si quiero construir tristeza, me iré con algo más emotivo, un piano o algo cinematográfico, si quiero acción, por algo más épico u orquestal, etc. En base a eso uno decide lo que te pide el spot. Uno trabaja con el corte del spot con la edición finalizada, tú planteas la estructura del tema. Cómo lo desarrollaría?, a ti te dan el corte final, y bajo todo o que has hablado con el creativo ya tienes la referencia escogida y trabajas sobre ese corte y vas ubicando los espacios o lugares donde tienes que generar climax y vas armando tu estructura, pintando y haciendo los arreglos

5. ¿de qué depende usar música de archivo, adaptar o crear? ¿considera que alguno es mejor o depende a qué situación se adecue mejor?

"Es mucho mejor usar música original, es insuperable, porque está hecha para ese producto, entonces estamos hablando de generar sensaciones, la música original se va a adaptar a las necesidades del spot, en cambio la de archivo va a generar pero no se va a adaptar, ello depende del presupuesto, normalmente la de archivo se usa para temas de web, ya que no es tan importante como la que va para televisión. La música de archivo se puede repetir en cualquier cosa que escuches por ahí. Lo mejor es trabajar con algo original, pero si es algo interno o se va a ver en los canales de la empresa música de archivo, la cual, últimamente, está creciendo. Considero que mejor es usar música original.

6. ¿cuán importante es la música en la publicidad?

"La música es súper importante. Prende la televisión y has el experimento, mira una tanda de comerciales y en mute. La música le da un ritmo a la imagen, generar sensaciones, a veces hace que las cosas duren menos, la música hace que las cosas fluyan, que el mensaje entre con mayor facilidad, que se entienda mejor y su función es imperceptible, uno no se da cuenta que está siendo manipulado por la música" 
7. Si has tenido la oportunidad de producir algún comercial para fragancias comenta tu experiencia

"No he tenido la oportunidad de producir para comerciales de fragancias, pero he grabado locuciones para estos. Generalmente estos comerciales tienen canciones ya hechas de artistas no conocidos, pero tienen esta atmósfera elegante, sensual, buscan que seas único, que vas a generar una diferencia"

\section{Ricardo Tafur - Productor musical en “Barracuda estudio}

1. ¿Cuáles son los factores fundamentales en la pre - producción musical para un spot publicitario?

"Creo que mucho tiene que ver saber bastante de que trata el producto, si no sabes en un $80 \%$ no vas a tener una idea de qué se quiere transmitir al público, saber también el público objetivo, qué intenta transmitir el publicista al público con lo que va a hacer, sea digital, por tele o radio, son esos tres factores, conocer el producto, el público objetivo y qué sensación quieren trasmitir a ese público objetivo.

2. ¿En qué medida y cuánto afecta la música a un spot publicitario? ¿de qué depende el impacto?

"En un $100 \%$, si ves un comercial sin un fondo musical la persona no se va a sentir identificada, no va a tener sentimiento con respecto a la imagen que te estén mostrando, entonces yo creo que tiene que ver mucho, demasiado diría yo, de qué tan bien este relacionada la música con la imagen que te estén mostrando o de lo que te estén hablando, esa relación, ese lazo de música con imagen es mucho, es como que te pongan una película de terror sin música, ni siquiera te va a asustar. 
3. ¿Cómo se trabaja o trata un producto conceptual (ej: perfumes/olor) al momento de crear una pista para su spot? (cómo se concibe en la pre - producción) ¿cómo lo desarrollarías?

"Creo que como todo producto tiene que tener la idea bien clara de qué se quiere transmitir, saber si es un perfume, en este caso, para hombre o mujer, adolescentes, niños, o ya un de repente un público más avanzado, la persona que viene a hacer la contratación del producto te especifica todo eso y de acuerdo a eso tú vas estudiando, por ejemplo para un público que se merodea entre los 23 a 35 años, el perfume un black xs para caballero debe ser una música de repente más atrevida, porque yo creo que por ese lado estaría trabajando la seducción, tú oliendo bien vas a atraer más mujeres, en este caso, valga la redundancia, esto es lo que toman ellos, vas a ser un macho, un poquito atrevido, un poquito de sensualidad, yo lo trabajaría de esa manera.

4. Criterios para la elección de un género y estilo en un spot publicitario

"Si es que fuera un perfume, primero escucharía la sugerencia del cliente, es muy raro que te den la libertad de elegir un estilo, normalmente te dicen, quiero algo así, tú puedes ir con propuestas, pero ellos lo eligen, pero yo tomo en cuenta para elegir el estilo bastante el público al cual está dirigido y qué representa la marca, qué quieren mostrar, mucho de lo que vas a poder tomar en cuenta para elegir eso es simplemente a qué público va y qué quieren mostrar, porque puede ser un perfume para personas mayores o si es uno más atrevido como Paco Rabbane, su línea es atrevida, joven, de 20 a 35 años y su música es sensual, mucho tienes que ver eso para saber que música usar en la pauta 
5. ¿De qué depende usar música de archivo, adaptar o crear? ¿considera que alguno es mejor o depende a qué situación se adecue mejor?

“Depende del cliente, tú puedes proponer muchas cosas, pero si el cliente se cierra y quiere algo eso va a ser, sea archivo, sea adaptación o desde cero. Hay clientes que prefieren una determinada canción o de repente quieren la última parte de un verso, esto va mucho con el cliente. Los publicitarios y nosotros, es un debate, normalmente se sientan y conversan al respecto, obviamente tú vas a tirar el lado de crear, porque si creas digamos que económicamente es mejor para el estudio, pero si ya es una canción de archivo o una adaptación se mueve de otra manera, el cual se va a usar depende del cliente. No considero que uno es mejor que otro, va a depender de lo que va a querer expresar el cliente, yo creo que todo sirve, todos son funcionales. Lo que si fuera malo es que la publicidad no tuviese música"

6. ¿Cuán importante es la música en la publicidad?

"Es demasiado importante, es una forma de transmitir sentimiento y es una forma de que mucha publicidad se te quede en la cabeza, así sea una tonadita chiquita, como el comercial de claro, el comercial de "te clavo la sombrilla", la canción sola en propaganda se hizo un hit, ahí tenemos un clarísimo ejemplo de que la música en una pauta es demasiado importante."

\section{Mauricio Chau - Productor musical independiente y músico en "Los terapeutas del ritmo}

1. ¿Cuáles son los factores fundamentales en la pre - producción musical para un spot publicitario?

“Pienso que fundamental es hacer un buen brief del producto con el cliente, saber de qué va el producto, de qué va la marca, cómo quieren verse reflejados en el mercado de su competencia, como piensan destacar, si es un tema de 
precio, si es un tema de carácter, yo creo que eso es fundamental antes de hacer cualquier sonido.

2. ¿En qué medida y cuánto afecta la música a un spot publicitario? ¿De qué depende el impacto?

'Yo creo que la música define sobre todo el carácter del producto, si es sexy, si es divertido, si es misterioso, si es adulto, serio, responsable, sólido, líder, un tema de confianza, todo eso se puede manejar a través de la música y el impacto. Yo creo que tiene que ver más en dónde se va a mostrar, porque de repente puede cambiar el mismo carácter en una ciudad diferente, en una comunidad diferentes, solo por los antecedentes y por el momento en donde está viviendo esa comunidad o ese país con respecto a su entorno de vida común."

3. ¿Cómo se trabaja o trata un producto conceptual (Ej: Perfumes/olor) al momento de crear una pista para su spot? (Cómo se concibe en la pre producción) ¿Cómo lo desarrollarías?

"Primero pensaría en dónde se va a mostrar este producto, además también el formato, si es radio, televisión o cine en internet, y en base a eso trabajaría, en base al brief, el concepto de carácter que el cliente le quiere dar a la marca o lo que las estadísticas han mostrado que es como se le percibe a la marca y en base a eso trabajaría el ritmo primero y luego una música, habría que ver si es que hay algún texto o letra o coro que sea necesario para reforzar la idea del producto

4. Criterios para la elección de un género y estilo en un spot publicitario

"Yo creo que el criterio lo da el lugar, el entorno en dónde va a ser mostrado, hacia qué mercado va, a quiénes va dirigido, si es gente joven o gente mayor, es 
un factor la edad para definir que un género puede sonar romántico o alegre, la alegría en diferentes edades se muestra con géneros diferentes, al igual que las palabras, textos y maneras de comunicar, las jergas que pueden crear una sintonía directa con el público principal, algún tipo de palabra modismo o cosas así, yo creo que ahí están los criterios."

5. ¿De qué depende usar música de archivo, adaptar o crear? ¿Considera que alguno es mejor o depende a qué situación se adecue mejor?

“Yo creo que depende básicamente del presupuesto y del cliente, si al cliente le parece que una cosa especifica va a calzar de manera más profunda o exacta hacia su consumidor o es que algo así genérico de galería le puede calzar, yo creo que tiene que ver también con qué tipo de producto es, quizás, un banco pueda calzar en varios tipos de galería, a menos que necesariamente quieras que se identifique con una música. Decía presupuesto porque esas galerías tienen un costo, un tiempo de uso y limitaciones, y cuando uno trabaja con música que ya existe, esta tiene autores, productores, ingenieros, disqueras representantes, editoras y todo lo que hay que pagar si es que quieres usarlo. Cada cual tiene sus ventajas, en la galería tienes ahí como un archivo de varias canciones, las que puedes escoger rápidamente y de una vez sales a la calle con tu spot publicitario, y porque de repente no tienes mucho presupuesto y quieres algo barato, pero lo malo es que otro producto puede tener tu misma galería, el problema de ellas es que son baratas, pero cualquiera lo puede usar, de repente un producto diferente al tuyo este usando la misma música, a pesar de que se adecua no es exclusivo. En cambio, la música creada especialmente para es justamente eso, nadie más la va a usar solamente el cliente, usualmente suele ser más caro, depende del ensamble, cuantos músicos vas a utilizar, el tiempo de la producción, eso toma su tiempo, siempre hay un tema físico para la realización 
6. ¿Cuán importante es la música en la publicidad?

'La música es importante por cuanto tiene una carga emocional fuera de los motivos razonables que puede tener un producto, un motivo racional de compra tiene el respaldo de un tema emocional, algo que aparentemente no resalta a primera vista aunque esto depende del producto, sientes como una emoción que te maneja la energía en favor del producto.

\section{Gonzalo polar - Productora musical en "Farmacia, casa de audio publicitario*}

1. ¿Cuáles son los factores fundamentales en la pre - producción musical para un spot publicitario?

“Lo que se ve en la preproducción con respecto a la música es la atmósfera que la música va a aportar al spot. Para ser sincero, en el caso de la música lo que se ve en la preproducción, que suele ser una referencia y una explicación de lo que se busca transmitir, es para "calmar" al cliente, porque hasta que la pieza de video no está editada cualquier decisión con respecto al audio no es para nada definitiva. Quizás ayuda al momento de editar, pero donde realmente se toman decisiones musicales es con la pieza de video ya armada."

2. ¿En qué medida y cuánto afecta la música a un spot publicitario? ¿De qué depende el impacto?

La medida y el impacto dependen del concepto general del spot. Muchas veces la música sirve para dirigir la percepción hacia determinadas sensaciones, pero otras es solo un complemento de lo que vemos en las imágenes. Lo que si es cierto es que puede ser determinante en la dirección emocional que puede tomar una pieza audiovisual, por eso tiene que ser pensada y realizada con cuidado. 
3. ¿Cómo se trabaja o trata un producto conceptual (Ej: Perfumes/olor) al momento de crear una pista para su spot? (Cómo se concibe en la pre producción) ¿Cómo lo desarrollarías?

En el caso de un producto así probablemente habría un paso previo para traducirlo en música. Muchas veces se habla de que un olor es 'juvenil", "elegante" o "alegre", además del target demográfico, y a partir de eso y de lo que se quiere contar en imágenes se plantea una ruta. Hay determinar qué género musical, qué velocidad debe tener para el ritmo de edición, la instrumentación (cantidad de instrumentos), el tipo de timbres sonoros (electrónicos o acústicos). Muchas veces se busca una referencia de música ya existente para presentarle al cliente y tenga una idea del camino por el cual queremos ir, y esta es la que usualmente se usa para editar el offline.

4. Criterios para la elección de un género y estilo en un spot publicitario

Hay criterios técnicos que se relacionan con el ritmo de edición, como el tempo de la música (velocidad), compás (3/4, 4/4); criterios estéticos como la instrumentación, tonalidad (mayor, menor, modal), y el género se decide según el target demográfico al cual va dirigido el spot. No es obligatorio, es decir, no necesariamente un comercial juvenil debe tener reggaetón o uno para gente muy adulta jazz o baladas, pero hay valores asociados a la edad o al nivel sociocultural que influyen en la elección de la música.

5. ¿De qué depende usar música de archivo, adaptar o crear? ¿Considera que alguno es mejor o depende a qué situación se adecue mejor?

La decisión entre música de archivo o creada depende casi exclusivamente del presupuesto. La música de archivo suele estar bien producida, pero los contras que tiene son que no son hechas a medida y no son exclusivas, con lo cual uno se corre el riesgo de escuchar una música de archivo que ya usó en un comercial de una marca distinta. La música adaptada y la compra de licencias se producen cuando existe una obra original preexistente y conocida que es 
parte de la idea creativa. Es más, muchas veces esas ideas no funcionan si no se usa esa determinada obra musical.

6. ¿Cuán importante es la música en la publicidad?

Muy importante, tanto y a veces más que las imágenes. Basta con ver un spot con "mute" o hacer el ejercicio de ponerle una música distinta a la original para darnos cuenta de qué tanto puede variar la transmisión emocional de determinada pieza audiovisual.

\section{Entrevista Luche Bedoya - Productora musical en "Farmacia, casa de audio“}

1) ¿Cuáles son los factores fundamentales en la pre - producción musical para un spot publicitario?

“los factores fundamentales son las referencias que te da el director del spot, para la música que desea.

2) ¿En qué medida y cuánto afecta la música a un spot publicitario? ¿De qué depende el impacto?

“La música vendría a ser el 50\% del spot, llegando a veces a ser incluso más"

3) ¿Cómo se trabaja o trata un producto conceptual (Ej: Perfumes/olor) al momento de crear una pista para su spot? (Cómo se concibe en la pre producción) ¿Cómo lo desarrollarías?

"El impacto: que la música es que llegue a compenetrar perfecto con el vídeo dando una sensación de armonía entre los dos..

4) Criterios para la elección de un género y estilo en un spot publicitario 
“criterio... Depende de la temática del vídeo, por ejemplo si es un vídeo sobre algo familiar la Música es como más cálida“

Si es algo tipo tecnología: La música es como de una sensación más fría

5) ¿De qué depende usar música de archivo, adaptar o crear? ¿Considera que alguno es mejor o depende a qué situación se adecue mejor?

“Depende del presupuesto del cliente y de su elección, y también influye el tema de derecho de autor (por difusión)

Ninguna es mejor o peor, lo ideal sería trabajar desde 0 con la música los cortes del vídeo, cosa que calza perfecto con el ritmo visual

6) ¿Cuán importante es la música en la publicidad?

"Siendo el 50\% del total, la música y la sonorización es muy importante para el trabajo final ${ }^{*}$

\section{Zonia palacios: Jefa del área de Marketing de L'Oréal en Perú}

1. ¿Cómo se trata el tema de la imagen de la marca en Perú?

Las marcas que yo he manejado son marcas internacionales selectivas Lancome, arflorel, Armani, Cacharel de la división de lujo, marcas selectivas del grupo L'Oréal. Importante comentar que son internacionales manejadas bajo una sola imagen, la imagen de marca es manejada en París, en la central, se envía no solo la comunicación como tal, sino la imagen del producto que se va a lanzar o que se va a comercializar de las diferentes maneras, es una imagen igual para todas partes del mundo, la comunicación es igual para todas partes del mundo, es más la traducción viene solo de la central, inclusive puede ser que alguna país de Latinoamérica lo traduzca México o argentina igual para todo el mundo, cuando se lanza un producto antes hace diez años primero era USA o 
Europa luego en Latinoamérica ahora la política es lanzarlo en el mismo mes y momento en todas partes del mundo, entonces las comunicaciones que tú ves en alguna publicidad apropiada para las marcas, cosas, vanidades o encartes de belleza es una imagen trabajada en la central, es la misma modelo, se pagan los derechos para las publicaciones.

2. En caso de que hayan utilizado spots televisivos, ¿cuáles eran los factores importantes al momento de aprobarlos en Lima a nivel audiovisual?, ¿cuáles crees que hayan sido los criterios?

Ampliando un poco la respuesta para la pregunta uno, no sé hace ningún desarrollo publicitario, menos spots publicitarios locales, ningún país del mundo por ende Perú. Es el dpto. de marketing quien se encarga de recibir esta información desde la central y luego pasar las piezas a los medios en los que uno va a publicar, en las agencias, depende del país, siempre son internacionales que manejan las mismas piezas en todo el mundo, algunas marcas trabajan con publicistas, pero es una sola agencia para la marca para todas partes del mundo donde haya una central o subsidiaria.

En cuanto a spots televisivos la publicidad en los canales siempre va depender del público objetivo, estamos hablando de marcas selectivas si sobre todo para fragancias y sobretodo en cable, difícil que algún País hubiera optado o publicado o anunciado en algún canal local, aquí en el Perú nunca se hizo ninguna inversión local tampoco en cable, porque recibíamos en muchas ocasiones cuando había un lanzamiento estratégico para alguna marca se hacía una contrataciones regional esta podía ser desde usa o desde argentina si se hacía alguna negociación algún contrato para Fox para Sony o para ciertos programas, recibíamos esa publicidad también si es que teníamos ese canal y si la gente hacia la contratación de canal de cable, nunca ningún desarrollo local, siempre una publicidad al igual que las piezas impresas, un desarrollo desde la matriz siempre Francia dependiendo si era Jorgio Armani o de Italia, siempre la matriz Francia, salían toda la comunicación para los diferentes países, estas 
marcas solamente existen en países donde hay subsidiarias,, no agentes, salvo que sea una distribución, pero si hablamos de Perú se recibía la info de la matriz y en spot publicitarios no se hacía desarrollo ni contratación local, se reciben algunas inversiones por cable por contratos regionales

3. ¿Cuán importante crees que es la música en un spot publicitario de productos de cuidado personal dirigido a mujeres?

La música siempre es importante es un fondo importante, el sonido, para cualquier spot publicitario definitivamente es un sentido que acompaña toda la partes esta visual sobre todo por lo que evoca si estas hablando de un perfume mиy sexy o floral muy joven siempre la música tiene que ver mисho con este acompañamiento ofondo, experiencias, poco hemos hecho, cuando se ha hecho publicidad televisiva en spots por ejemplo Raph Lauren, muy joven moderna, muy americana, para Ralph que es una marca para chicas jóvenes, a veces contratan estos conjuntos americanos nuevos y hacían un spot muy pop, para L ebel, que es de lancome, más que el sonido era la locución, era una locución bastante dirigida a una mujer en una fiesta sexy con cristales y una voz en off acompañaba mucho esto y más que nada el ruido de esta foto o lo que pudiera estar desarrollándose en la parte visual., en el caso de Giorgio Armani siempre trabajaba algo muy sensual en la playa en el campo, siempre había una música más de fondo, alejada, importante, pero siempre desarrollos muy propios, nunca compraban alguna música

4. ¿Cómo definirías a la mujer joven como consumidora en Lima en torno a productos de cuidado personal?

En general, cuidado personal es un rubro que está creciendo, es cultural también si lo separamos a nivel de cremas, digamos cada día las mujeres son más conscientes del cuidado que tienen que tener, no quieren arrugas ni manchas, está creciendo definitivamente, hay más puntos de venta, la gente tiene más opciones, si hablamos de productos selectivos, depende de los 
ingresos, va a comprar un hidratante Lancome, Loreal, más está creciendo el rubro de maquillaje, es moda, es color, es juventud, uñas, nuevas marcas de esmalte, labios. Acaban de entrar marcas como Nyx, Reblon, Maybelline. Fragancias no estoy tan segura, no veo nuevos lanzamientos como antes, que cada marca lanzaba nueva fragancia, están renovando, en cuidado personal crecen más maquillaje, o cremas, es bastante amplio

5. ¿Qué emociones cree que deba transmitir un comercial de productos de esta categoría en Lima? Por qué?

Depende de lo que el producto quieran transmitir, si es un producto natural libertad frescura, si va por los olores otro tipo de emociones, hay que definir, a dónde quieres llegar, quién quieres que te compre, y que emociones son las que ese grupo objetivo busca desarrollar, si hablamos de cremas hay que evocar a la juventud, hay que evocar a sentirse joven en todo sentido, verse joven, mantener una piel que irradie básicamente juventud, siempre la palabra Juventud va a estar centrada en este tipo de productos, libertad es otra emoción importante cuando uno desarrollar comerciales de productos, uno quiere sentirse en el campo, siempre sale una chica corriendo sobretodo en shampoo o cremas, y fragancias, la fragancia es más sutil, sus emociones son recuerdos, tu evocas mucho con el sentido del olfato, son recuerdos, puedes tener 5 fragancias y una evoca la que saliste con tu amigas, tu esposo, con tu enamorado con tu hijo, una fiesta, hay mucho más que puedes utilizar con fragancias básicamente son emociones.

6. ¿Cómo se posicionan productos de esta categoría en el público femenino en Lima?

El posicionamiento en un producto cosmético, bueno, eso depende de lo que la compañía quiere con su producto, primero cual es el costo, porque si es caro tiene ingredientes de alta tecnología, tú lo vas a poder posicionar en un nivel socioeconómico alto y la venta tiene que ser un lugar apropiado a 
donde va ese público tiendas por departamento si es un producto genérico porque el envase o la fórmula no es tan caros, es un producto de venta más amplio, en tiendas donde no tengas consultoras de belleza, supermercados o catálogo. 